\title{
Development of Two Alpine Bluegrass Reclamation Varieties
}
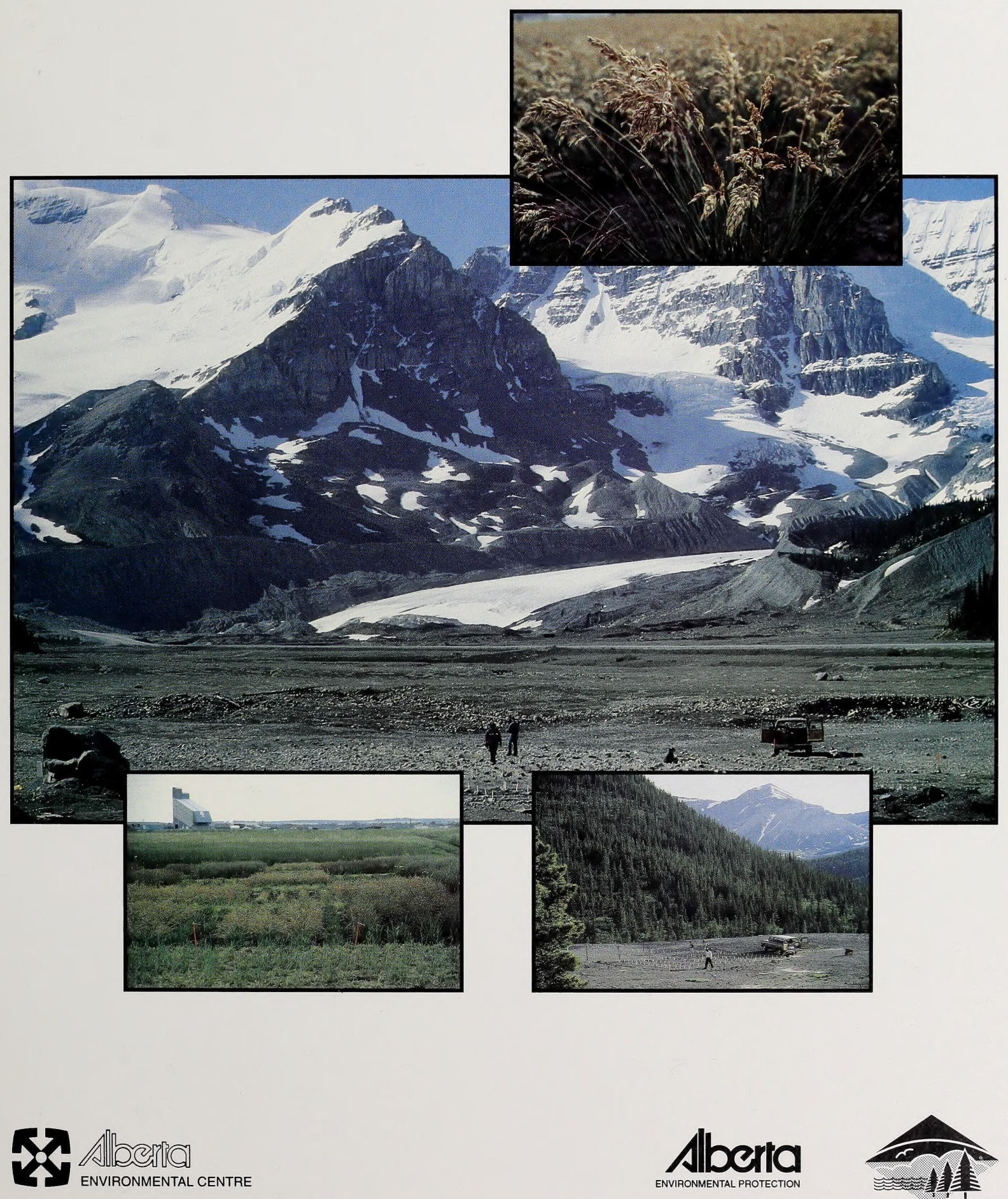
Digitized by the Internet Archive in 2016 
DEVELOPMENT OF TWO ALPINE BLUEGRASS RECLAMATION VARIETIES

\author{
B.A. DARROCH \\ PLANT BREEDER \\ ENVIRONMENTAL ENHANCEMENT \\ ALBERTA ENVIRONMENTAL CENTRE \\ BAG 4000 \\ VEGREVILLE, AB T9C 1T4
}

May 8, 1996 
Copies of this publication are available from:

Communications and Office Support

Alberta Environmental Centre

Department of Environmental Protection

Postal Bag 4000

Vegreville, AB Canada T9C 1T4

Ph: $\quad(403) 632-8403$

Fax: (403)632-8379

This publication may be cited as:

Darroch, B.A. 1996. Development of Two Alpine Bluegrass Reclamation Varieties. Alberta Environmental Centre, Vegreville, AB. AECV96-R1. 124 pp.

ISBN 0-7732-5184-7 


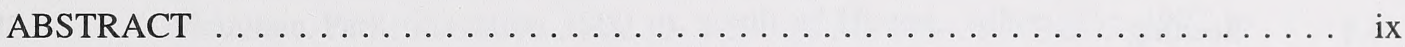

$2.1 \quad$ AEC Blueridge Alpine Bluegrass $\ldots \ldots \ldots \ldots \ldots \ldots \ldots \ldots \ldots \ldots$

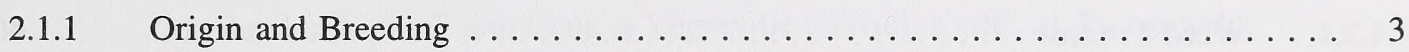

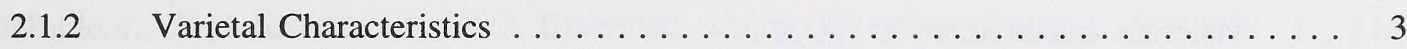

2.1.3 Performance $\ldots \ldots \ldots \ldots \ldots \ldots \ldots \ldots \ldots \ldots \ldots \ldots \ldots \ldots \ldots$

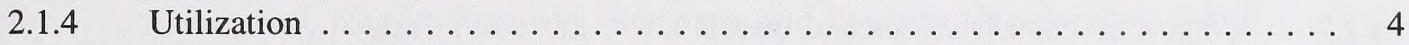

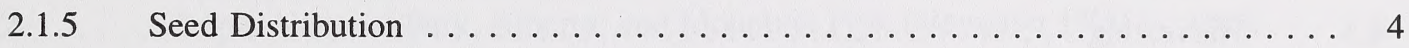

$2.2 \quad$ AEC Glacier Alpine Bluegrass $\ldots \ldots \ldots \ldots \ldots \ldots \ldots \ldots \ldots$

2.2.1 Origin and Breeding $\ldots \ldots \ldots \ldots \ldots \ldots \ldots \ldots \ldots \ldots \ldots \ldots$

2.2.2 Varietal Characteristics $\ldots \ldots \ldots \ldots \ldots \ldots \ldots \ldots \ldots \ldots \ldots$

2.2.3 Performance $\ldots \ldots \ldots \ldots \ldots \ldots \ldots \ldots \ldots \ldots \ldots \ldots \ldots$

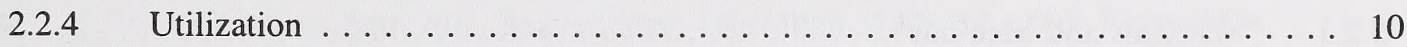

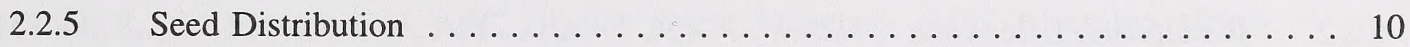

3 DEVELOPMENT OF VARIETIES $\ldots \ldots \ldots \ldots \ldots \ldots \ldots \ldots \ldots$

3.1 Collection of Plant Material and Initial Selection $\ldots \ldots \ldots \ldots \ldots \ldots \ldots$

$3.2 \quad$ Provenance Trials $\ldots \ldots \ldots \ldots \ldots \ldots \ldots \ldots \ldots \ldots \ldots \ldots \ldots$

3.2.1 Materials and Methods $\ldots \ldots \ldots \ldots \ldots \ldots \ldots \ldots \ldots \ldots \ldots$

3.2.2 Results and Discussion $\ldots \ldots \ldots \ldots \ldots \ldots \ldots \ldots \ldots \ldots \ldots \ldots \ldots$

Multilocation Trials $\ldots \ldots \ldots \ldots \ldots \ldots \ldots \ldots \ldots \ldots \ldots \ldots \ldots$ 




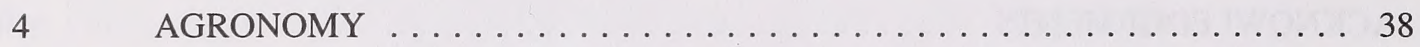

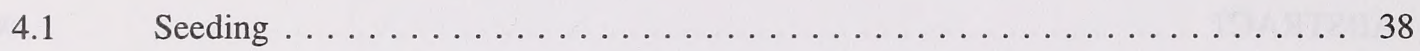

4.1.1 Materials and Methods $\ldots \ldots \ldots \ldots \ldots \ldots \ldots \ldots \ldots \ldots \ldots \ldots$

4.1.2 Results and Discussion $\ldots \ldots \ldots \ldots \ldots \ldots \ldots \ldots \ldots \ldots \ldots \ldots \ldots$

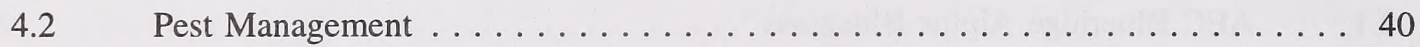

$4.2 .1 \quad$ Weed Control $\ldots \ldots \ldots \ldots \ldots \ldots \ldots \ldots \ldots \ldots \ldots \ldots \ldots$

4.2.1.1 Materials and Methods $\ldots \ldots \ldots \ldots \ldots \ldots \ldots \ldots \ldots \ldots \ldots \ldots$

4.2.1.2 Results and Discussion $\ldots \ldots \ldots \ldots \ldots \ldots \ldots \ldots \ldots \ldots \ldots \ldots$

4.2.2 Control of Plant Diseases and Insects $\ldots \ldots \ldots \ldots \ldots \ldots \ldots \ldots \ldots \ldots$

$4.3 \quad$ Harvesting $\ldots \ldots \ldots \ldots \ldots \ldots \ldots \ldots \ldots \ldots \ldots \ldots \ldots \ldots \ldots \ldots$

$4.4 \quad$ Post-Harvest Management $\ldots \ldots \ldots \ldots \ldots \ldots \ldots \ldots \ldots \ldots \ldots \ldots$

5 MANAGEMENT PRACTICES FOR USE IN RECLAMATION $\ldots \ldots \ldots \ldots .49$

$5.1 \quad$ Species/Variety Selection $\ldots \ldots \ldots \ldots \ldots \ldots \ldots \ldots \ldots \ldots \ldots$

$5.2 \quad$ Seeding, Establishment, and Stand Maintenance ............. 50

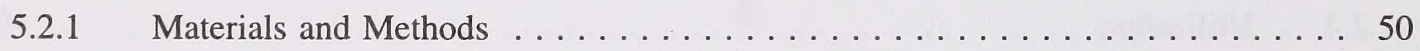

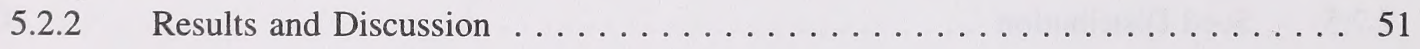

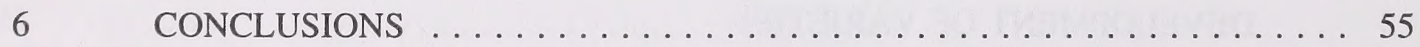

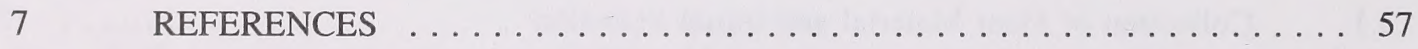




\section{LIST OF TABLES}

PAGE

Table 1. Performance of AEC Blueridge alpine bluegrass, Nugget Kentucky bluegrass, and Reubens Canada bluegrass in small plot trials seeded in 1990 at Columbia Icefields (elevation $1860 \mathrm{~m}$, Jasper National Park, Alberta) and Mountain Park (elevation 1800 m, south of Hinton, Alberta) in 1992 to 1994

Table 2. Performance of AEC Blueridge alpine bluegrass, Nugget Kentucky bluegrass, and Reubens Canada bluegrass in the first year of seed production in small plot trials at Vegreville (elevation $640 \mathrm{~m}$ ), Beaverlodge (elevation $730 \mathrm{~m}$ ), and Plamondon (elevation $560 \mathrm{~m}$ ), Alberta ........ 6

Table 3. Performance of AEC Blueridge alpine bluegrass, Nugget Kentucky bluegrass, and Reubens Canada bluegrass in the second year of seed production in small plot trials at Vegreville (elevation $640 \mathrm{~m}$ ), Beaverlodge (elevation $730 \mathrm{~m}$ ), and Plamondon (elevation $560 \mathrm{~m}$ ), Alberta . . . . . . .

Table 4. Performance of AEC Blueridge alpine bluegrass, Nugget Kentucky bluegrass, and Reubens Canada bluegrass in the third year of seed production in small plot trials at Vegreville (elevation $640 \mathrm{~m}$ ), Alberta . . . . .

Table 5. Performance of AEC Glacier alpine bluegrass, AEC Blueridge alpine bluegrass, Nugget Kentucky bluegrass, and Reubens Canada bluegrass in small plot trials seeded in 1990 at Columbia Icefields (elevation $1860 \mathrm{~m}$, Jasper National Park, Alberta) and Mountain Park (elevation 1800 m, south

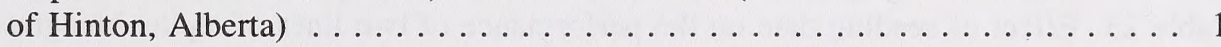

Table 6. Performance of AEC Glacier alpine bluegrass, AEC Blueridge alpine bluegrass, Nugget Kentucky bluegrass, and Reubens Canada bluegrass in the first year of seed production in small plot trials at Vegreville (elevation $640 \mathrm{~m}$ ), Beaverlodge (elevation $730 \mathrm{~m}$ ), and Plamondon (elevation $560 \mathrm{~m}$ ), Alberta

Table 7. Performance of AEC Glacier alpine bluegrass, AEC Blueridge alpine bluegrass, Nugget Kentucky bluegrass, and Reubens Canada bluegrass in the second year of seed production in small plot trials at Vegreville (elevation $640 \mathrm{~m}$ ), Beaverlodge (elevation $730 \mathrm{~m}$ ), and Plamondon (elevation $560 \mathrm{~m}$ )

Table 8. Performance of AEC Glacier alpine bluegrass, AEC Blueridge alpine bluegrass, Nugget Kentucky bluegrass, and Reubens Canada bluegrass in the third year of seed production in small plot trials at Vegreville (elevation $640 \mathrm{~m})$, Alberta

Table 9. Performance of selected alpine bluegrass lines in Transplanted Provenance Trial 1 (established in 1988) at Columbia Icefields in 1989 to 1994 . . . . . . .

Table 10. Performance of selected alpine bluegrass lines in Transplanted Provenance Trial 2 (established in 1989) at Columbia Icefields in 1990 to 1994 . . . . . . . 22

Table 11. Performance of selected alpine bluegrass lines in transplanted provenance trial (established in 1989) at Mountain Park in 1990 to 1994

Table 12. Performance of selected alpine bluegrass lines in transplanted provenance trial (established in 1987) at Sunshine Village in 1989 to 1993 
Table 13. Performance of selected alpine bluegrass lines in seeded provenance trial (established in 1987) at Columbia Icefields in 1989 to 1994 . .

Table 14. Performance of selected alpine bluegrass lines in seeded provenance trials (established in 1987 and 1988) at Sunshine Village in 1989 to 1993 . . . . . . 26

Table 15. Performance of selected alpine bluegrass lines in the transplanted provenance trial (established in 1987) at Vegreville in 1988 and 1989 . . . . . 27

Table 16. Performance of selected alpine bluegrass lines in seeded provenance trials at Vegreville in 1988 to 1991.

Table 17. Mean performance of selected alpine bluegrass lines in multilocation trials at Columbia Icefields in 1991 to 1994

Table 18. Mean performance of selected alpine bluegrass lines in multilocation trials at Mountain Park in 1991 to 1994

Table 19. Mean performance of selected alpine bluegrass lines in the first year of seed production in multilocation trials at Vegreville, Beaverlodge, and



Table 20. Mean performance of selected alpine bluegrass lines in the second year (1992) of seed production in multilocation trials at Vegreville, Beaverlodge, and Plamondon ............................. 36

Table 21. Mean performance of selected alpine bluegrass lines in the third year (1994) of seed production in a multilocation trial at Vegreville . . . . . . . . . . .

Table 22. Effect of seeding date on the performance of two lines of alpine bluegrass in the first year of seed production in small plot trials (seeded in 1992 and 1993) at Vegreville . . . . . . . . . . . . . . . . . . . . . . .

Table 23. Effect of seeding date on the performance of two lines of alpine bluegrass in the second year (1994) of seed production in a small plot trial at

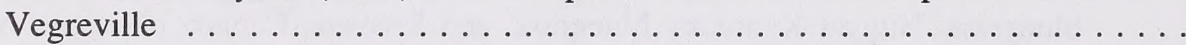

Table 24. Effect of 14 herbicide treatments on potted plants of common alpine bluegrass when applied at the 2-leaf and 5-leaf stages of growth in a

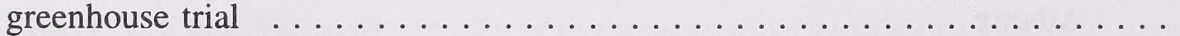

Table 25. Effect of five herbicide treatments on potted plants of common alpine bluegrass when applied at the 2-leaf and 5-leaf stages of growth in a greenhouse trial

Table 26. Effect of seeding date and the use of peat moss as a soil amendment on common alpine bluegrass in small plot trials at Columbia Icefields and



Table 27. Effect of seeding date on the emergence and percent cover of common alpine bluegrass in a small plot trial at Columbia Icefields 
Figure 1. Collection area and locations used to test selected lines

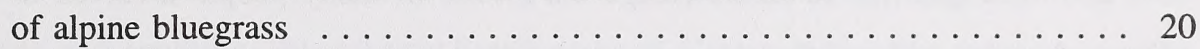

\section{LIST OF APPENDICES}

PAGE

APPENDIX A - PERFORMANCE OF ALPINE BLUEGRASS LINES IN INDIVIDUAL PROVENANCE TRIALS $\ldots \ldots \ldots \ldots \ldots \ldots \ldots 1$

APPENDIX B - $\quad$ PERFORMANCE OF ALPINE BLUEGRASS LINES IN INDIVIDUAL MULTILOCATION TRIALS $\ldots \ldots \ldots \ldots \ldots 97$

APPENDIX C - METEOROLOGICAL DATA FOR RESEARCH SITES . . . . . . 121 


\section{ACKNOWLEDGEMENTS}

I would like to acknowledge the efforts of many people involved in this project: R. Hermesh, who initiated the research project and helped with many aspects of the research; S. Acharya who began the plant breeding work and made initial selections; technical staff including M. Pahl, J. Woosaree, B. James, and D. Pewarchuk and numerous summer and support staff, whose expert technical assistance was essential in developing these varieties; N. Fairey of Agriculture and Agri-Food Canada, Beaverlodge, who provided land and assistance in multilocation trials. The financial support of Parks Canada and the Alberta Agricultural Research Institute is also gratefully acknowledged. I would like to thank C. Powter of the Reclamation Research Technical Advisory Committee for his support and advice throughout this research project. I am also grateful to R. Hermesh and L. Dosdall for critically reviewing the manuscript. 


\section{ABSTRACT}

To address the need for seed of native grasses adapted for reclaiming disturbed sites in the mountains and foothills, the Alberta Environmental Centre initiated a research project aimed at developing and releasing varieties of native grasses. Four native grass species were included in this project: alpine bluegrass (Poa alpina), slender wheatgrass (Elymus trachycaulus, including awnless slender wheatgrass [ssp. trachycaulus], awned slender wheatgrass [ssp. subsecundus], and broadglumed wheatgrass [ssp. violaceus]), Rocky Mountain fescue (Festuca saximontana), and spike trisetum (Trisetum spicatum). Plants of these species were collected from the eastern slopes of the Rocky Mountains in 1984 and 1985. Alpine bluegrass was one of the most promising species of these four. It establishes and grows well on a wide range of soils and is an active colonizer on most disturbances in subalpine and alpine environments. Alpine bluegrass is non-competitive and allows other native plant species to invade a reclaimed site. This helps to create a more natural plant community on reclaimed land.

Fifteen lines of alpine bluegrass were selected for evaluation in provenance trials at Vegreville, Columbia Icefields, Sunshine Village, and Mountain Park. Data from these trials were used to select eight alpine bluegrass lines for final evaluation in multilocation trials at Vegreville, Beaverlodge, Plamondon, Columbia Icefields, and Mountain Park. Based on the information collected in these trials, two reclamation varieties of alpine bluegrass were released by the Alberta Environmental Centre. AEC Blueridge alpine bluegrass was released in 1994. It is a high-elevation variety adapted to elevations as high as $2500 \mathrm{~m}$. AEC Glacier alpine bluegrass, which was released in 1994, is adapted to elevations as high as $2400 \mathrm{~m}$ and is better adapted to drier conditions than AEC Blueridge. Although these varieties were released as pure lines, we recommend that they be incorporated into seed mixtures containing other native plant

species and varieties to maximize genetic and species diversity and improve the likelihood of obtaining a good plant cover in any one location. In addition to developing and releasing these reclamation varieties, research has also been conducted to develop recommendations for growing these varieties for seed production and for use in reclamation and revegetation. 

INTRODUCTION

Increasing public awareness about the importance of biodiversity and ecosystem integrity has led to increased interest in the use of native plants in reclamation, revegetation, and restoration. Sites in the mountains and foothills may be disturbed by such activities as resource extraction, pipeline and road construction, recreation and recreational development, and forestry operations. At high elevations, reclamation and revegetation of disturbed sites is especially difficult due to harsh environmental conditions. Commercially available varieties of introduced plant species often cannot survive at high elevations so they cannot provide long-term cover. At lower elevations, introduced species may be highly competitive and persistent (Hardy BBT Ltd. 1990) and will not allow native plants to invade a reclaimed site. Thus, sites revegetated with introduced species may always maintain their distinct vegetative cover, disrupting the natural ecosystems surrounding them.

The major advantage of using native plants in reclamation is that they are adapted to the area in which they are found. Native species are generally better adapted to low soil fertility and the short growing seasons characteristic of high elevations (Hardy BBT Ltd. 1990). Brown et al. (1976) reported that introduced grasses, while initially successful on high elevation sites, declined in vigour and productivity by the third growing season. Native grasses, on the other hand, were more vigourous and had greater productivity. Since they are adapted to lower nutrient conditions (Hardy BBT Ltd. 1990), native plants require fewer inputs to maintain a good stand over the long term (Thornburg 1982). Native plants fit well into the surrounding ecosystem and help to maintain ecosystem integrity when used in reclamation plantings. Native species are generally not highly competitive and will allow other native plants to invade naturally from surrounding, undisturbed areas.

The agrology of native plants is poorly understood so establishment and maintenance of plant stands may be difficult (Joyce 1993; Bradley 1994). Stand establishment is often slow, weed control is difficult due to the non-competitive nature of native species, and seed yield may be low and unpredictable (Joyce 1993). Introduced species have been widely used in reclamation partly because of the availability of inexpensive seed. The high cost of native grass seed reflects its low availability and high cost of production (Joyce 1993). Use of locally-collected seed in reclamation may be desirable in some situations (Hardy BBT Ltd. 1990; Mahler 1990), but seed 
collection is very expensive and seed production in the wild is unpredictable. For large-scale reclamation projects, the cost of collected seed is often prohibitive. In addition, seeds produced in alpine environments germinate more slowly and exhibit more dormancy than those produced in prairie nurseries (Hermesh and Acharya 1992). Therefore, the best alternative is to use commercial sources of native plant seed but such sources are not readily available.

To address the problem of seed availability, the Alberta Environmental Centre (AEC) initiated research in 1984 with the objective of selecting, testing, developing, and releasing varieties of native grasses suitable for use in reclamation of disturbed lands in the mountains and foothills of Alberta. Four native species with potential for use in reclamation were chosen for development: alpine bluegrass (Poa alpina L.), slender wheatgrass (Elymus trachycaulus (Link) Gould in Shinners, including awnless slender wheatgrass [ssp. trachycaulus], awned slender wheatgrass [ssp. subsecundus (Link) Gould], and broadglumed wheatgrass [ssp. violaceus (Horneman) A.\& D. Love]), Rocky Mountain fescue (Festuca saximontana Rydb.), and spike trisetum (Trisetum spicatum (L.) Richt.). These species were chosen because they occur in a wide range of habitats and colonize disturbed sites.

This report documents the development and release of two varieties of alpine bluegrass. Alpine bluegrass is a cool-season, perennial bunch-grass (Hardy BBT Ltd. 1989). It is found in subalpine to alpine meadows and rocky slopes and has a circumpolar distribution (Moss 1983). Apomixis is common in alpine bluegrass biotypes of northern countries (Müntzing 1954; Müntzing and Müntzing 1971) and plants collected in Alberta also appear to reproduce apomictically. Alpine bluegrass will grow on bare soils, acidic mine spoils, and talus slopes and has been described as an active colonizer on most disturbances in alpine environments (Hardy BBT Ltd. 1989). It is ideally suited to reclamation of disturbed sites at high elevations.

In 1984, plants of alpine bluegrass were collected in the eastern slopes of the Rocky Mountains. Following initial selections, all selected lines were extensively tested in the mountains and foothills and at plains sites from 1987 to 1994 . Potential varieties should be compared to standard varieties over a period of years at several locations (Allard 1960). This ensures that all released varieties will perform well, both in their areas of adaptation and for seed production at lower elevations. In addition to developing varieties, research was conducted to determine the most appropriate techniques for growing alpine bluegrass for seed production and reclamation. 
$2.1 \quad$ AEC Blueridge Alpine Bluegrass

AEC Blueridge alpine bluegrass, Poa alpina L., was released by the Alberta Environmental Centre in 1994 for use in reclaiming disturbed sites in the mountains and foothills of Alberta. AEC Blueridge is the first variety of alpine bluegrass released in Canada. It is adapted to the short growing seasons of high elevations and can grow rapidly and produce mature seed at elevations as high as $2500 \mathrm{~m}$.

\subsubsection{Origin and Breeding}

AEC Blueridge (designated as line 1760) was derived from a single plant collected in 1985 from a site (elevation $2150 \mathrm{~m}$ ) near the Alberta-British Columbia border. It was part of a collection of alpine bluegrass plants from 235 sites in the eastern slopes of the Rocky Mountains. The seed from this plant has been multiplied and tested through successive generations. AEC Blueridge has been primarily evaluated for seed production, growth, and vigour. Breeder seed was first bulked in 1989 (in the third generation from collected plants).

\subsubsection{Varietal Characteristics}

AEC Blueridge alpine bluegrass is a perennial bunch-grass which reproduces apomictically, a characteristic common in alpine bluegrass (Müntzing 1954; Müntzing and Müntzing 1971). Plants are generally 15 to $35 \mathrm{~cm}$ tall and leaves are mostly basal. Leaf blades are 8 to $12 \mathrm{~cm}$ long and 2 to $5 \mathrm{~mm}$ wide, ending in a boat-shaped tip. The head is an open panicle, pyramidal in shape. There are five to six florets per spikelet and spikelets have a purplish colour. Glumes are unequal and have short tip awns less than $1 \mathrm{~mm}$ long. Lemmas are hairy, especially on the keel and marginal nerves. Lemmas have no awn tips.

\subsubsection{Performance}

AEC Blueridge alpine bluegrass was compared to Nugget Kentucky bluegrass (Poa pratensis) and Reubens Canada bluegrass (Poa compressa) in evaluation trials because there are no other varieties of alpine bluegrass. This complicated the evaluation because alpine bluegrass is a bunch-grass whereas Kentucky bluegrass and Canada bluegrass have rhizomatous growth 
habits (Hodgson et al. 1971; Jacklin 1976). In trials at mountain sites, AEC Blueridge clearly outperformed both check varieties, producing greater cover and higher seed yields (Table 1). In some cases, AEC Blueridge produced seed when the check varieties produced none. This was due in part to the early maturity of AEC Blueridge. At the mountain sites, it is ripe by late July to early August while seed of Nugget or Reubens may not ripen until late September or early October. At elevations as high as $2400 \mathrm{~m}$ AEC Blueridge produced seed heads, although these heads did not always ripen by the beginning of September. AEC Blueridge had seed yields similar to those of both Nugget and Reubens in the first year of seed production at plains locations (Table 2). It produced fewer heads than either check variety and seed size was intermediate between Nugget and Reubens (Tables 2, 3, 4). AEC Blueridge matured approximately 2 wk earlier than Nugget and 3 to 4 wk earlier than Reubens. It also tended to be shorter than the check varieties. In the second year of seed production, AEC Blueridge had seed yields similar to those of Nugget but less than those of Reubens (Table 3). In the third year of seed production (one site only), seed yields were again similar to those of Nugget but much less than those of Reubens (Table 3).

\subsubsection{Utilization}

AEC Blueridge alpine bluegrass is primarily for use in reclaiming and revegetating disturbed sites in the mountains and foothills of Alberta up to an elevation of approximately $2500 \mathrm{~m}$. Its primary advantage over other varieties of bluegrass is its early maturity. It is capable of growing rapidly and producing mature seed in the short growing seasons found at high elevations. It may also be useful at more northerly locations where the growing season can be very short. When grown at low elevations, AEC Blueridge alpine bluegrass is short-lived (4 to $5 \mathrm{yr})$.

\subsubsection{Seed Distribution}

Breeder seed of AEC Blueridge alpine bluegrass will be maintained by the Alberta Environmental Centre, Vegreville, Alberta. Foundation and Certified seed will be multiplied and distributed by Prairie Seeds Ltd., RR \# 1, South Edmonton, Alberta, T6H 4 N6. 
Table 1. Performance of AEC Blueridge alpine bluegrass, Nugget Kentucky bluegrass, and Reubens Canada bluegrass in small plot trials seeded in 1990 at Columbia Icefields (elevation 1860 m, Jasper National Park, Alberta) and Mountain Park (elevation 1800 m, south of Hinton, Alberta) in 1992 to 1994.

\begin{tabular}{|c|c|c|c|c|c|c|}
\hline Location & $\begin{array}{c}\text { Year } \\
\text { Harvested }\end{array}$ & Variety & $\begin{array}{c}\text { Percent Cover } \\
(\%)\end{array}$ & $\begin{array}{c}\text { Seed } \\
\text { Yield } \\
\left(\mathrm{mg} \mathrm{m}^{-1}\right)\end{array}$ & $\begin{array}{l}\text { Number of Heads } \\
\left(\text { no. } \mathrm{m}^{-1}\right)\end{array}$ & $\begin{array}{c}\text { Plant Height } \\
(\mathrm{cm})\end{array}$ \\
\hline \multirow[t]{4}{*}{ Columbia Icefields } & 1992 & AEC Blueridge & 81.7 & 4.6 & 0.6 & 21.0 \\
\hline & & Nugget & 14.2 & 0.0 & 0.0 & - \\
\hline & & Reubens & 60.8 & 1.2 & 0.7 & 21.0 \\
\hline & & $\mathrm{SE}^{\dagger}$ & 7.8 & 3.8 & 0.3 & 1.0 \\
\hline \multirow[t]{4}{*}{ Columbia Icefields } & 1993 & AEC Blueridge & 17.5 & $-\ddagger$ & - & - \\
\hline & & Nugget & 2.8 & - & - & - \\
\hline & & Reubens & 14.2 & - & - & - \\
\hline & & SE & 3.9 & - & - & - \\
\hline \multirow[t]{4}{*}{ Columbia Icefields } & 1994 & AEC Blueridge & 45.0 & 4.3 & 0.2 & 20.0 \\
\hline & & Nugget & 4.2 & 0.0 & 0.0 & - \\
\hline & & Reubens & 20.8 & 0.5 & 0.1 & 17.0 \\
\hline & & SE & 10.0 & 5.0 & 0.2 & 1.3 \\
\hline \multirow[t]{4}{*}{ Mountain Park } & 1992 & AEC Blueridge & 20.0 & 34.3 & 2.4 & 20.8 \\
\hline & & Nugget & 6.7 & 5.6 & 0.2 & - \\
\hline & & Reubens & 18.3 & 12.2 & 5.6 & 23.8 \\
\hline & & SE & 2.1 & 8.5 & 0.9 & 1.4 \\
\hline \multirow[t]{4}{*}{ Mountain Park } & 1993 & AEC Blueridge & 32.5 & 33.8 & 4.1 & 19.3 \\
\hline & & Nugget & 12.0 & 0.0 & 0.5 & 14.5 \\
\hline & & Reubens & 27.5 & 0.0 & 3.2 & 19.6 \\
\hline & & SE & 2.7 & 7.7 & 0.8 & 1.2 \\
\hline \multirow[t]{4}{*}{ Mountain Park } & 1994 & AEC Blueridge & 56.7 & 174.2 & 7.6 & 18.7 \\
\hline & & Nugget & 10.8 & 5.8 & 1.2 & 13.0 \\
\hline & & Reubens & 40.8 & 23.2 & 3.7 & 28.0 \\
\hline & & SE & 9.4 & 25.3 & 1.3 & 1.7 \\
\hline \multirow[t]{3}{*}{ Mean } & & AEC Blueridge & 42.2 & 50.2 & 3.0 & 20.0 \\
\hline & & Nugget & 8.4 & 2.3 & 0.4 & 13.8 \\
\hline & & Reubens & 30.4 & 7.4 & 2.7 & 21.9 \\
\hline
\end{tabular}

${ }^{\dagger}$ Standard error based on 45 degrees of freedom.

${ }^{\ddagger}$ No or few seed heads produced in trial. 


\begin{tabular}{|c|c|c|c|c|c|c|}
\hline 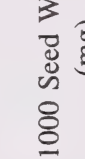 & 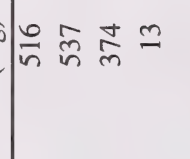 & 흄ㅇㅇㅇ & 总品品 $=$ & 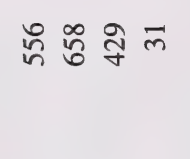 & 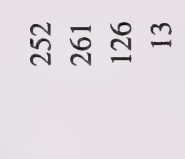 & 导识的 \\
\hline 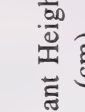 & 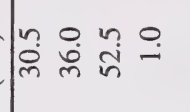 & 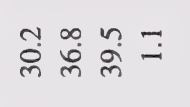 & 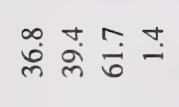 & 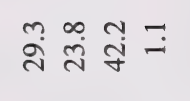 & 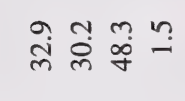 & $\begin{array}{l}\vec{m} \\
\bar{m}\end{array}$ \\
\hline 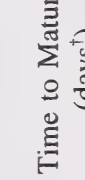 & 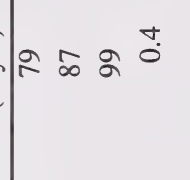 & $\ltimes \circ \stackrel{\infty}{\infty} \stackrel{\circ}{-}$ & $\approx \infty \cong \stackrel{\infty}{=}$ &  & 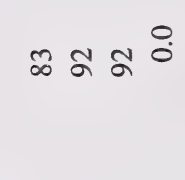 & $\infty \stackrel{\infty}{\sigma}$ \\
\hline 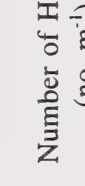 & $\overrightarrow{\widetilde{N}} \overline{\mathrm{F}}$ & 志骂 命 F & 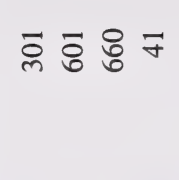 & ¿ & $\cong \mathscr{\Xi}$ & $\bar{\pi} \bar{d} \tilde{n}$ \\
\hline 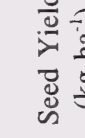 &  & さำ & 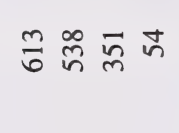 & 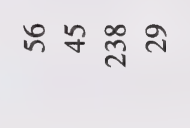 & $\stackrel{\infty}{\underline{a}}$ 홍 & $\bar{\sim} \cong \approx$ \\
\hline 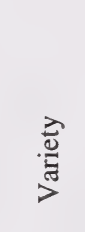 & 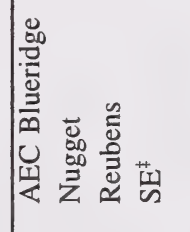 & 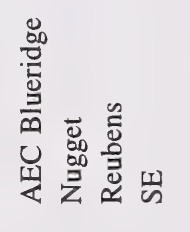 & 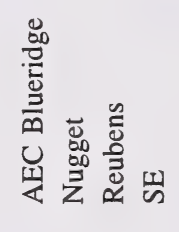 & 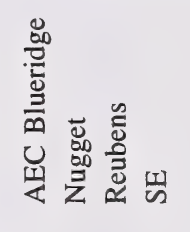 & 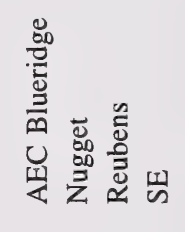 & 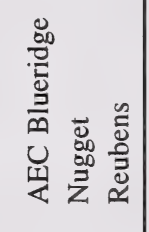 \\
\hline & 离 & Б & g & S & $\stackrel{g}{g}$ & \\
\hline 总 & 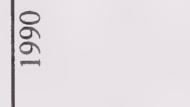 & ब & よ̃ & $\bar{\sigma}$ & ळ̆ & \\
\hline हू & $\mid$ & 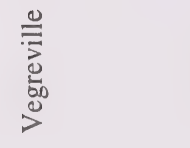 & 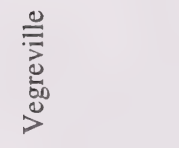 & 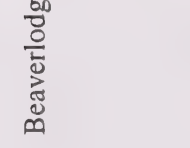 & 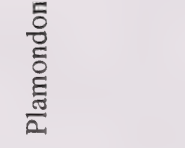 & $\sum_{\bar{\delta}}^{\bar{g}}$ \\
\hline
\end{tabular}







Table 4. Performance of AEC Blueridge alpine bluegrass, Nugget Kentucky bluegrass, and Reubens Canada bluegrass in the third year of seed production in small plot trials at Vegreville (elevation $640 \mathrm{~m}$ ), Alberta. Plots were seeded in 1991 and harvested in 1994.

\begin{tabular}{lccccc}
\hline Variety & $\begin{array}{c}\text { Seed Yield } \\
\left(\mathrm{kg} \mathrm{ha}^{-1}\right)\end{array}$ & $\begin{array}{c}\text { Number of Heads } \\
\left(\text { no. m }^{-1}\right)\end{array}$ & $\begin{array}{c}\text { Time to Maturity } \\
\left(\text { days }^{\dagger}\right)\end{array}$ & $\begin{array}{c}\text { Plant Height } \\
(\mathrm{cm})\end{array}$ & $\begin{array}{c}1000 \text { Seed Weight } \\
(\mathrm{mg})\end{array}$ \\
\hline AEC Blueridge & 33 & 181 & 79 & 42.3 & 472 \\
Nugget & 7 & 231 & 102 & 44.1 & 535 \\
Reubens & 21 & 970 & 104 & 76.0 & 276 \\
SE $^{\ddagger}$ & 14 & 78 & 1.4 & 2.7 & 16 \\
\hline
\end{tabular}

† Days from April 15 to maturity.

${ }^{\ddagger}$ Standard error based on 45 degrees of freedom. 
The Alberta Environmental Centre released AEC Glacier alpine bluegrass, Poa alpina L., in 1995 for use in reclamation and revegetation of disturbed sites at high elevations. As the second alpine bluegrass variety released by the Centre, AEC Glacier was released to complement AEC Blueridge alpine bluegrass. AEC Glacier is adapted to high elevations and is capable of rapid growth and seed production in short growing seasons. It also appears to be more drought tolerant than AEC Blueridge.

\subsubsection{Origin and Breeding}

AEC Glacier was derived from a single plant collected in 1985 from a site (elevation $1880 \mathrm{~m}$ ) in Phillip's Pass near the Crowsnest Pass in southwestern Alberta. It was part of a collection of alpine bluegrass plants from 235 sites in the eastern slopes of the Rocky Mountains. The seed from this plant was designated as line 1003 and has been multiplied and tested through successive generations. AEC Glacier has been primarily evaluated for seed production at plains sites, and for growth and vigour at mountain locations. Breeder seed was first bulked in 1989 (in the third generation from collected plants).

\subsubsection{Varietal Characteristics}

AEC Glacier alpine bluegrass is a perennial bunch-grass which reproduces apomictically, a characteristic common in northern biotypes of alpine bluegrass (Müntzing 1954; Müntzing and Müntzing 1971). Plants are generally 15 to $40 \mathrm{~cm}$ tall and leaves are mostly basal. Leaf blades are 8 to $12 \mathrm{~cm}$ long and 3 to $7 \mathrm{~mm}$ wide, ending in a boat-shaped tip. The head is an open panicle, pyramidal in shape. There are five to six florets per spikelet and spikelets have a bronze colour although the glumes may be somewhat purplish. Glumes are unequal and have short tip awns less than $1 \mathrm{~mm}$ long. Lemmas have pronounced hyaline margins and are hairy, especially on the keel and marginal nerves. Lemma tips have no awns.

\subsubsection{Performance}

Nugget Kentucky bluegrass (Poa pratensis) and Reubens Canada bluegrass (Poa compressa) were used as checks in alpine bluegrass evaluation trials because there were no varieties of alpine bluegrass available for comparison. This complicated the evaluation because 
alpine bluegrass is a bunch-grass whereas Kentucky bluegrass and Canada bluegrass have rhizomatous growth habits (Hodgson et al. 1971; Jacklin 1976). In trials at mountain sites, AEC Glacier outperformed the check varieties, producing greater cover and higher seed yields (Table 5). Percent cover values for AEC Glacier were similar to those for AEC Blueridge although AEC Blueridge produced more seed. Like AEC Blueridge, AEC Glacier ripened by late July to early August while seed of Nugget or Reubens did not ripen until late September or early October, when heavy frosts have probably reduced seed viability. At elevations as high as 2400 $\mathrm{m}$ AEC Glacier produced seed heads, but these heads ripened by the beginning of September only when the growing seasons were favourable (longer). AEC Glacier had higher seed yields than Nugget, Reubens, or AEC Blueridge in the first year of seed production at plains locations (Table 6). It produced fewer heads than the other varieties but it seemed to be more capable of filling seed heads during the dry conditions encountered in most years at these sites. This is reflected by its high seed weights, second only to the large-seeded Nugget. In the second and third years of seed production, AEC Glacier maintained its seed yield advantage over the other varieties (Tables 7,8). AEC Glacier matured approximately 1 wk earlier than AEC Blueridge, 3 to 4 wk earlier than Nugget, and 4 to 5 wk earlier than Reubens. It tended to be shorter than Nugget and Reubens but was similar to AEC Blueridge in height.

\subsubsection{Utilization}

AEC Glacier alpine bluegrass is primarily for use in reclaiming and revegetating disturbed sites in the mountains and foothills of Alberta up to an elevation of approximately $2400 \mathrm{~m}$. Its primary advantage over other bluegrass species is its early maturity. It is capable of growing rapidly and producing mature seed in the short growing seasons found at high elevations. AEC Glacier appeared to have more drought tolerance than AEC Blueridge, producing greater seed yields under dry conditions. When grown at low elevations, AEC Glacier alpine bluegrass is short-lived ( 4 to $5 \mathrm{yr}$ ).

\subsubsection{Seed Distribution}

Breeder seed of AEC Glacier will be maintained by the Alberta Environmental Centre, Vegreville, Alberta. The multiplication and distribution of Foundation and Certified seed will be handled by Prairie Seeds Ltd., RR \# 1, South Edmonton, Alberta, T6H 4 N6. 
Table 5. Performance of AEC Glacier alpine bluegrass, AEC Blueridge alpine bluegrass, Nugget Kentucky bluegrass, and Reubens Canada bluegrass in small plot trials seeded in 1990 at Columbia Icefields (elevation 1860 m, Jasper National Park, Alberta) and Mountain Park (elevation 1800 m, south of Hinton, Alberta).

\begin{tabular}{|c|c|c|c|c|c|c|}
\hline Location & $\begin{array}{c}\text { Year } \\
\text { Harvested }\end{array}$ & Variety & $\begin{array}{c}\text { Percent Cover } \\
\text { (\%) }\end{array}$ & $\begin{array}{l}\text { Seed Yield } \\
\left(\mathrm{mg} \mathrm{m}^{-1}\right)\end{array}$ & $\begin{array}{l}\text { Number of Heads } \\
\left(\text { no. } \mathrm{m}^{-1}\right)\end{array}$ & $\begin{array}{l}\text { Plant Height } \\
(\mathrm{cm})\end{array}$ \\
\hline \multirow[t]{5}{*}{ Columbia Icefields } & 1992 & AEC Glacier & 84.2 & 5.9 & 0.6 & 20.0 \\
\hline & & AEC Blueridge & 81.7 & 4.6 & 0.6 & 21.0 \\
\hline & & Nugget & 14.2 & 0.0 & 0.0 & - \\
\hline & & Reubens & 60.8 & 1.2 & 0.7 & 21.0 \\
\hline & & $\mathrm{SE}^{\dagger}$ & 7.8 & 3.8 & 0.3 & 1.0 \\
\hline \multirow[t]{5}{*}{ Columbia Icefields } & 1993 & AEC Glacier & 17.5 & $-\neq$ & - & - \\
\hline & & AEC Blueridge & 17.5 & - & - & - \\
\hline & & Nugget & 2.8 & - & - & - \\
\hline & & Reubens & 14.2 & - & - & - \\
\hline & & SE & 3.9 & - & - & - \\
\hline \multirow{5}{*}{ Columbia Icefields } & 1994 & AEC Glacier & 53.3 & 0.0 & 0.0 & - \\
\hline & & AEC Blueridge & 45.0 & 4.3 & 0.2 & 20.0 \\
\hline & & Nugget & 4.2 & 0.0 & 0.0 & - \\
\hline & & Reubens & 20.8 & 0.5 & 0.1 & 17.0 \\
\hline & & SE & 10.0 & 5.0 & 0.2 & 1.3 \\
\hline \multirow[t]{5}{*}{ Mountain Park } & 1992 & AEC Glacier & 18.3 & 10.8 & 0.6 & 19.3 \\
\hline & & AEC Blueridge & 20.0 & 34.3 & 2.4 & 20.8 \\
\hline & & Nugget & 6.7 & 5.6 & 0.2 & - \\
\hline & & Reubens & 18.3 & 12.2 & 5.6 & 23.8 \\
\hline & & SE & 2.1 & 8.5 & 0.9 & 1.4 \\
\hline \multirow[t]{5}{*}{ Mountain Park } & 1993 & AEC Glacier & 24.2 & 3.7 & 0.4 & 15.3 \\
\hline & & AEC Blueridge & 32.5 & 33.8 & 4.1 & 19.3 \\
\hline & & Nugget & 12.0 & 0.0 & 0.5 & 14.5 \\
\hline & & Reubens & 27.5 & 0.0 & 3.2 & 19.6 \\
\hline & & SE & 2.7 & 7.7 & 0.8 & 1.2 \\
\hline \multirow[t]{5}{*}{ Mountain Park } & 1994 & AEC Glacier & 50.8 & 74.0 & 4.5 & 18.2 \\
\hline & & AEC Blueridge & 56.7 & 174.2 & 7.6 & 18.7 \\
\hline & & Nugget & 10.8 & 5.8 & 1.2 & 13.0 \\
\hline & & Reubens & 40.8 & 23.2 & 3.7 & 28.0 \\
\hline & & SE & 9.4 & 25.3 & 1.3 & 1.7 \\
\hline \multirow[t]{4}{*}{ Mean } & & AEC Glacier & 41.4 & 18.9 & 1.2 & 18.2 \\
\hline & & AEC Blueridge & 42.2 & 50.2 & 3.0 & 20.0 \\
\hline & & Nugget & 8.4 & 2.3 & 0.4 & 13.8 \\
\hline & & Reubens & 30.4 & 7.4 & 2.7 & 21.9 \\
\hline
\end{tabular}

†Standard error based on 45 degrees of freedom.

${ }^{\ddagger}$ No or few seed heads produced in trial. 







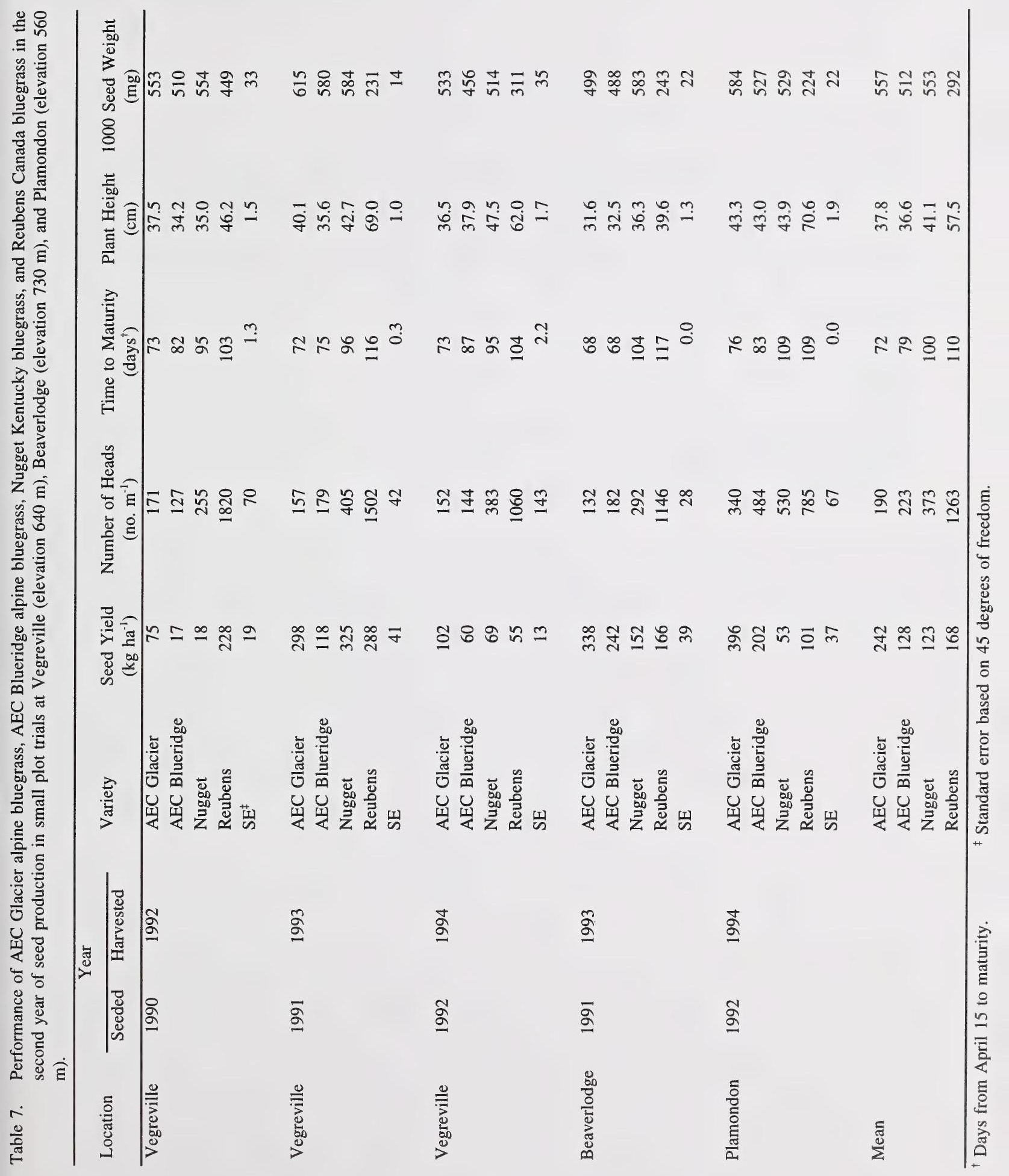


Table 8. Performance of AEC Glacier alpine bluegrass, AEC Blueridge alpine bluegrass, Nugget Kentucky bluegrass, and Reubens Canada bluegrass in the third year of seed production in small plot trials at Vegreville (elevation 640 m), Alberta. Plots were seeded in 1991 and harvested in 1994.

\begin{tabular}{lccccc}
\hline Variety & $\begin{array}{c}\text { Seed Yield } \\
\left(\mathrm{kg} \mathrm{ha}^{-1}\right)\end{array}$ & $\begin{array}{c}\text { Number of Heads } \\
\left(\text { (no. m }^{-1}\right)\end{array}$ & $\begin{array}{c}\text { Time to Maturity } \\
\left(\text { days }^{\dagger}\right)\end{array}$ & $\begin{array}{c}\text { Plant Height } \\
(\mathrm{cm})\end{array}$ & $\begin{array}{c}\text { 1000 Seed Weight } \\
(\mathrm{mg})\end{array}$ \\
\hline AEC Glacier & 147 & 215 & 70 & 42.4 & 502 \\
AEC Blueridge & 33 & 181 & 79 & 42.3 & 472 \\
Nugget & 7 & 231 & 102 & 44.1 & 535 \\
Reubens & 21 & 970 & 104 & 76.0 & 276 \\
SE $^{\ddagger}$ & 14 & 78 & 1.4 & 2.7 & 16 \\
\hline
\end{tabular}

${ }^{\dagger}$ Days from April 15 to maturity.

₹ Standard error based on 45 degrees of freedom. 


\subsection{Collection of Plant Material and Initial Selection}

Systematic collections of plants of alpine bluegrass were made in 1984 and 1985. These collections were part of a germplasm collection of four species; plants of slender wheatgrass, spike trisetum, and Rocky Mountain fescue were also collected at the same time. A total of 317 collection sites were used and alpine bluegrass plants were found at 235 of these sites. Collection sites were located in the eastern slopes of the Rocky Mountains from the United States border in the south to Jasper townsite, Jasper National Park, in the north (Fig. 1). Alpine bluegrass collection sites varied in elevation from $900 \mathrm{~m}$ to $2770 \mathrm{~m}$. These elevational and latitudinal gradients were used to maximize genetic diversity within the germplasm collection. Most plants were collected from disturbed or poorly vegetated sites. At each site, approximately 10 plants of each species were collected. Plants were dug up with roots and attached soil, bagged, and stored on ice during transportation to Vegreville. Plants were kept in transit for a maximum of three days.

Collected plants were transplanted into pots and nurtured for two weeks in growth chambers with day/night temperatures of $22 / 15^{\circ} \mathrm{C}$. Plants were then hardened in sheltered outdoor conditions before being transplanted into a field nursery. A total of 2551 plants of alpine bluegrass were transferred to a field nursery with over $98 \%$ transplantation success. Initially, 446 plants of alpine bluegrass were selected from the field nursery. Of these, approximately 133 plants produced sufficient seed when grown in growth chambers for evaluation in progeny tests established in 1985 and 1986. Observations including general vigour, disease resistance, winter survival, height, tiller number, seed yield, and time to maturity were taken on all progeny rows. Based on the results of these trials, 15 lines of alpine bluegrass were selected for further evaluation in provenance trials. Because alpine bluegrass reproduces by apomixis (Müntzing 1954; Müntzing and Müntzing 1971), a pedigree selection method was used in the development of plant varieties of this species. Therefore, each line was derived from the seed of a single collected plant and maintained separately through successive generations. 


\subsection{Provenance Trials}

\subsubsection{Materials and Methods}

Provenance trials were established to evaluate 15 selected alpine bluegrass lines at three mountain locations and at Vegreville. Two agronomic varieties, Reubens Canada bluegrass (Poa compressa L.), and Nugget Kentucky bluegrass (P. pratensis L.), were included for comparison.

Trials were established at Vegreville (elevation $640 \mathrm{~m}$ ), Columbia Icefields (Jasper National Park, elevation 1860 m), Lookout Mountain (Sunshine Village in Banff National Park, elevation $2400 \mathrm{~m}$ ), and Mountain Park (south of Hinton, elevation $1800 \mathrm{~m}$ ) (Fig. 1). The site at Columbia Icefields was located on an abandoned gravel pit area, approximately $2 \mathrm{~km}$ north of the Athabasca Glacier. At Lookout Mountain, the trials were situated on a ski slope, and the site at Mountain Park was located on an abandoned coal tailings pile. At all three mountain sites, there was little or no topsoil present.

Both direct seeding and transplanting were used to establish these trials. At Vegreville, seeded provenance trials were established in 1987 (S1) and 1989 (S2) and the transplanted trial was established in 1987. At Columbia Icefields, one seeded trial was established in 1987 and two transplanted trials were established in 1988 (T1) and 1989 (T2). A second trial seeded in 1988 did not emerge or survive well and was later discarded. At Lookout Mountain, trials were seeded in 1987 (S1) and 1988 (S2) and the transplanted trial was established in 1987. The site at Mountain Park included only one transplanted provenance trial, established in 1989.

All seeded plots consisted of single $2 \mathrm{~m}$ rows, seeded by hand at the mountain sites in late June or July and with a small plot seeder at Vegreville in late May or June. Seeded provenance trials were replicated four times except for the trial at Columbia Icefields which had only three replicates. For transplanted trials, plants were seeded into root-trainers in the greenhouse in February or March, and hardened in sheltered outdoor conditions prior to transplanting into field trials in late June or early July. At Vegreville and Lookout Mountain, 20 plants per plot were used for each trial. At Columbia Icefields (T1) and Mountain Park, four plants per plot were used and in trial T2 at Columbia Icefields, each plot consisted of only three plants due to limited availability of plants. Five replicates were used in each transplanted provenance trial, except for $\mathrm{T} 2$ at Columbia Icefields which had only four replicates. All provenance trials were arranged in randomized complete block designs. 
Data collected from these trials included: winter survival, plant height, plant width, flag leaf length, flowering date, number of heads produced, maturity date, seed yield, and aboveground biomass. However, not all of these data were collected in every year at every site due to time limitations and limitations imposed by the climate at the mountain sites. For example, biomass was not taken in every year to avoid killing the plants by depleting root reserves. Analyses of variance of all data were conducted for each site in each year and for combined analyses over years using the general linear models (GLM) procedure of the SAS statistical package (SAS Institute, Inc. 1990). Mean separation was accomplished using Duncan's new multiple range test.

\subsubsection{Results and Discussion}

At mountain sites, plant establishment was generally better in transplanted trials than in seeded trials due to poor soil conditions. Soil analyses showed that there was no available nitrogen in the soil at Columbia Icefields and little nitrogen in soil at Mountain Park. There was no available phosphorous at either site. Soil analyses also showed that there was 56 to $98 \mathrm{~kg}$ available potassium ha ${ }^{-1}$ at Mountain Park, and 14 to $24 \mathrm{~kg} \mathrm{ha}^{-1}$ at Columbia Icefields. In spite of these low nutrient levels, the native grasses thrived in most trials at the mountain sites.

In transplanted provenance trial 1 at Columbia Icefields, plants survived well and in 1994, most plots still consisted of four plants. The largest mean number of heads was produced in 1989 but the highest mean seed yield was produced in 1994 (Table 9). Lines 752, 1760 (AEC Blueridge), and 1588 produced the most seed per plant. Line 1760 also produced the most above-ground biomass. Plant height and width were similar for all alpine bluegrass lines. Nugget Kentucky bluegrass was the shortest and both Nugget and Reubens Canada bluegrass produced the widest plants, due to their rhizomatous growth habit. In the second transplanted provenance trial at Columbia Icefields, the most heads and highest seed yields were observed in 1990 (Table 10). The top three lines for seed yield were 745, 752 and 1588. Line 1760 was not planted in this trial due to a shortage of plants when the trial was established. Lines 745 and 752 also produced the most heads per plant. Once again, Nugget produced very short plants and Reubens had the widest plants. There was little variation in flag leaf length in either transplanted trial at Columbia Icefields (Tables 9, 10). 
The transplanted provenance trial at Mountain Park appeared to be more variable from year to year than the trials at Columbia Icefields. Very little seed was produced in 1991 and 1993 although seed yields in 1990, 1992, and 1994 (Table 11) were comparable to those of the first transplanted provenance trial at Columbia Icefields (Table 9). Reubens Canada bluegrass and lines 745 and 1214 produced the most heads but heads produced on plants of Reubens were very small so it had only the fourth highest seed yield (Table 11). The highest mean seed yields per plant were produced by lines 1245, 1214, and 1003 (AEC Glacier). Reubens had the most above-ground biomass, partially due to the advantage gained by its rhizomatous growth habit. Lines 1214, 1229, and 1003 also had high biomass values. Nugget had the shortest plants and Reubens had the widest plants.

At Lookout Mountain, alpine bluegrass flowered but seed was still green when we visited the site to collect data in early September each year. Therefore, no seed yield data were obtained for this site. The most heads were produced in 1990 with lines 752, 745, and 864 producing the most heads per plant (Table 12). Above-ground biomass was highest in 1989 and lowest in 1993. It is uncertain whether this reflects a trend in declining plant productivity or was due to changing weather conditions. There was little variation among lines for plant height, width, or flag leaf length.

In the seeded provenance trial at Columbia Icefields, the most seed and heads were produced in 1990 (Table 13). Lines 745 and 752 had the highest number of heads. However, there were no significant differences in seed yield even though line 1267 had almost twice as much seed as the second best line (line 752). This was due to high variability from year to year. Percent cover remained fairly consistent over time with Reubens and Nugget giving the best cover values although there were no significant differences. Reubens and Nugget also produced the widest plants. Flag leaf length was similar for all lines and the check varieties. At Lookout Mountain, lines in the seeded provenance trials were evaluated for percent cover, number of heads, and plant height (Table 14). Due to high variability at this site, there were no significant differences among lines for any of the observed data. The best plant cover was observed in 1991 and line 1001 had the highest mean cover in both trials. The most heads were produced in 1993. At Vegreville, Reubens and lines 1003 (AEC Glacier) and 1760 (AEC Blueridge) produced the most seed in the transplanted provenance trial (Table 15). Seed yield was similar in both years of this trial. Reubens also produced the most seed heads, followed by lines 752 
and 745. Above-ground plant biomass was greatest for lines 1448, 1760, and 1588. Plant height and width were similar for all lines although Reubens had the tallest and widest plants. Alpine bluegrass lines ranged in maturity from 67 days after April 15 for lines 864 and 907 to 85 days for line 752. Reubens and Nugget matured last (87 days). Line 1267 had the heaviest seeds and line 1245 had the lightest seeds.

In the first seeded provenance trial at Vegreville, number of heads and seed yield decreased from the first to the second year of seed production (Table 16). However, these data remained fairly constant in the second trial. Mean number of heads and seed yield were highest for Reubens, followed by line 745 and Nugget. However, differences in seed yield among lines were not significant. The most above-ground biomass was produced by Reubens and lines 1588 and 1760. Time to maturity was similar to that observed in the transplanted provenance trial, with line 864 maturing first (67 days) and Nugget and Reubens maturing last (87 and 92 days, respectively). Nugget produced the heaviest seeds while Reubens had the lightest seeds.

Overall, it was difficult to pick out lines that clearly outperformed all others at all sites. Line 1760, later released as AEC Blueridge, did well at Columbia Icefields, but because of a shortage of plants, it was not evaluated at Mountain Park. Lines 1760 and 1003 (released as AEC Glacier) also performed well in provenance trials at Vegreville. Based on performance in these trials, five single lines, lines $907,1003,1448,1588$, and 1760, were chosen for further evaluation in multilocation trials. Other lines were also included as part of three line mixes. 


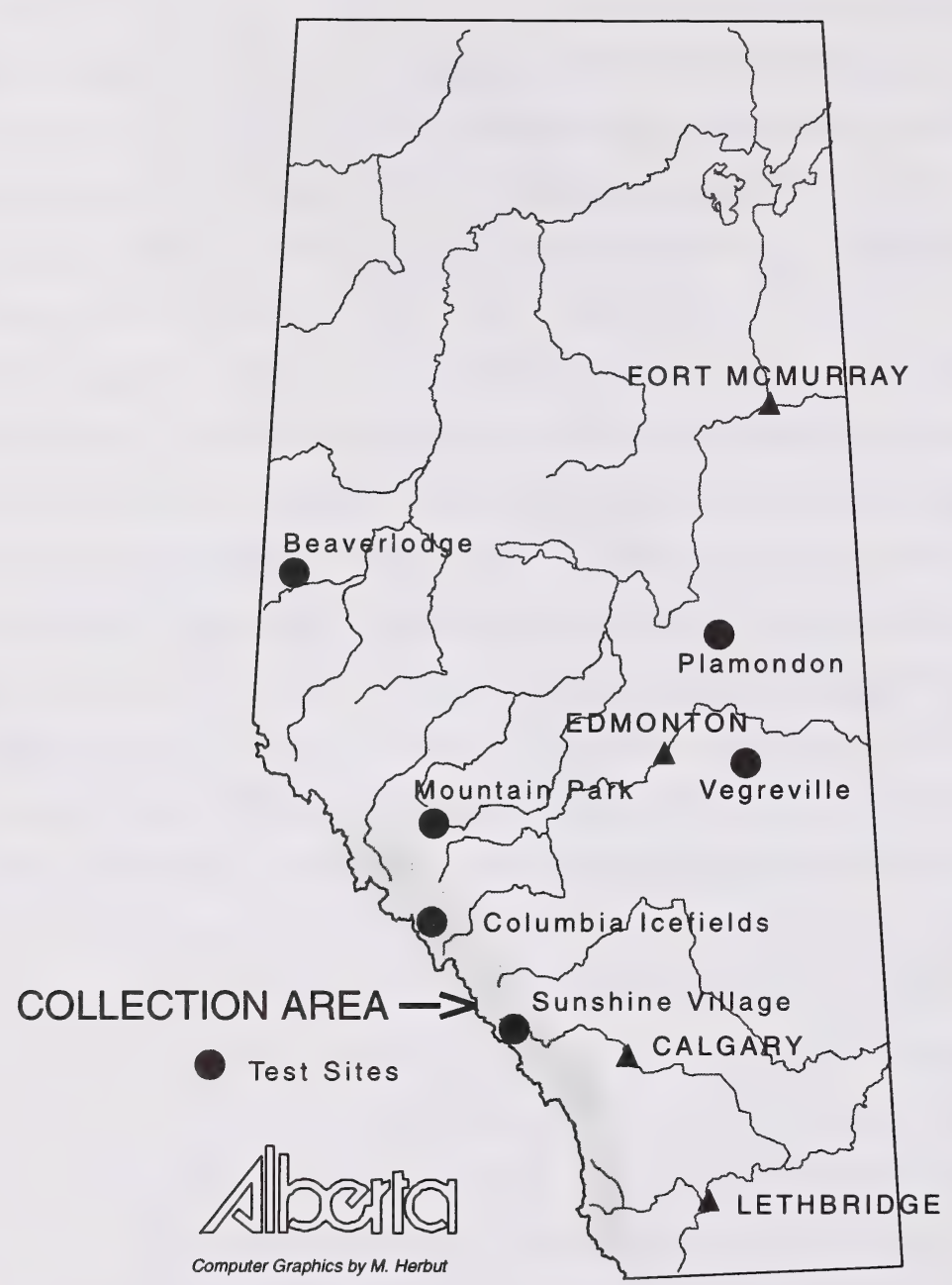

Fig. 1. Collection area and locations used to test selected lines of alpine bluegrass. 


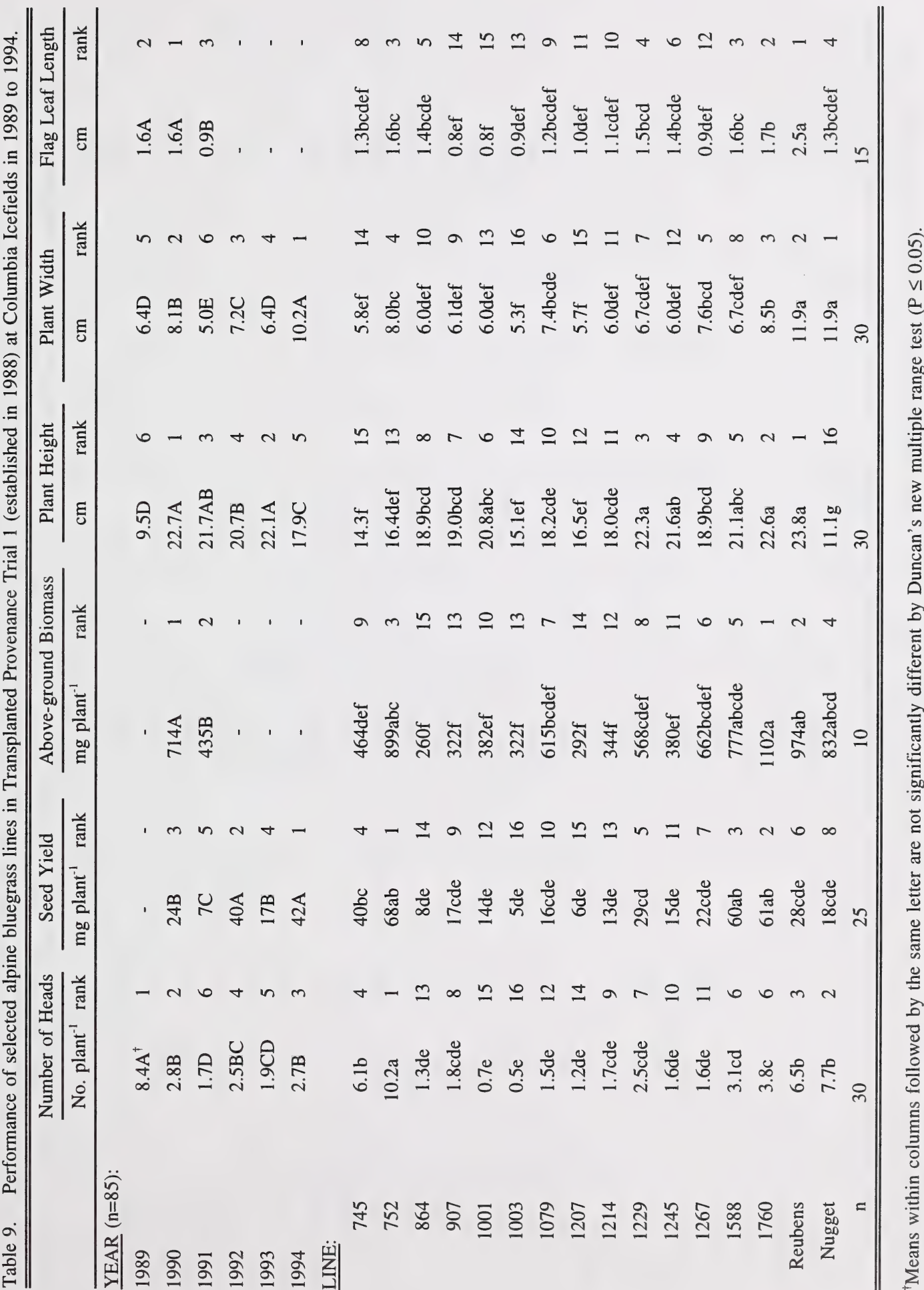









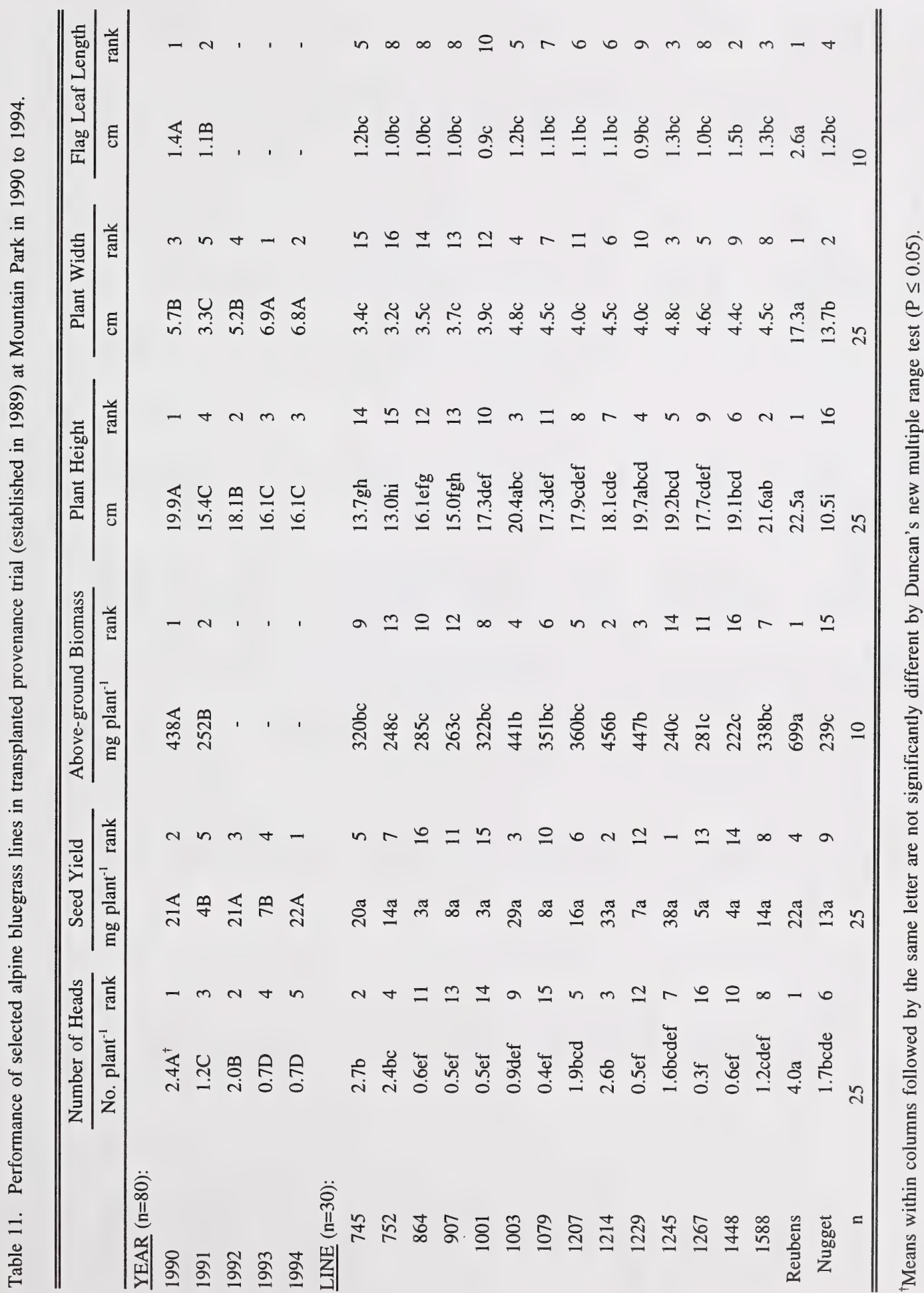




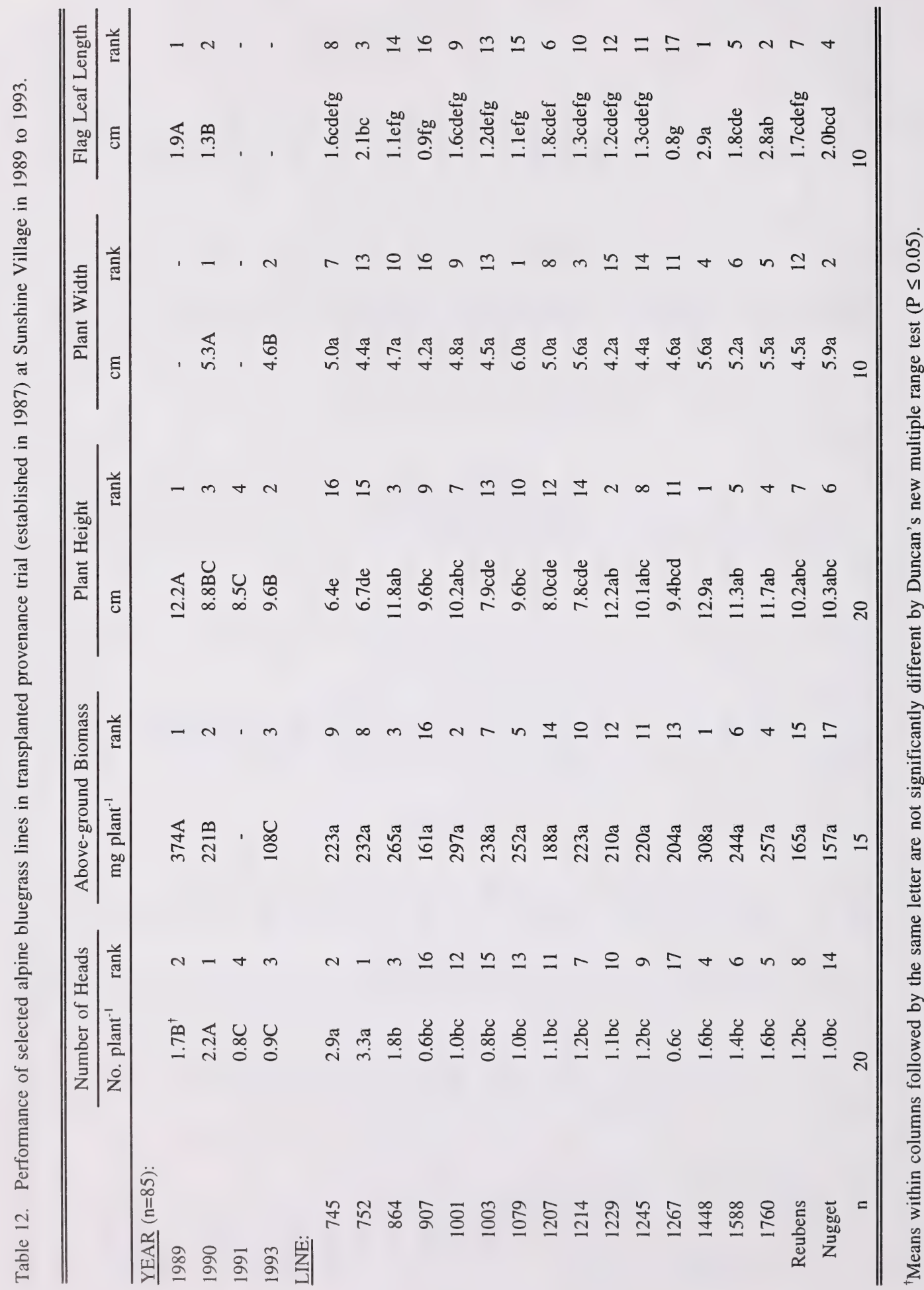









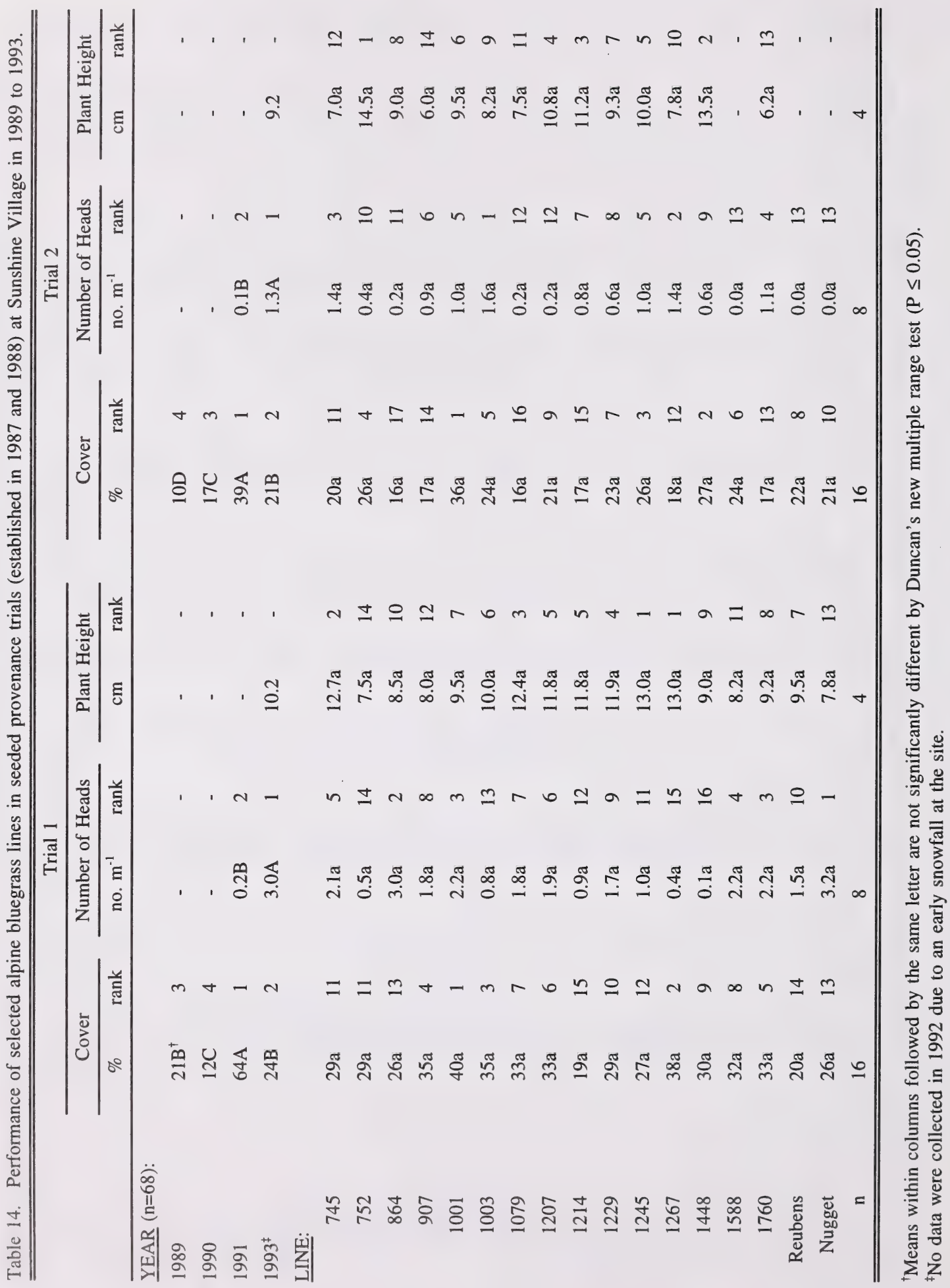




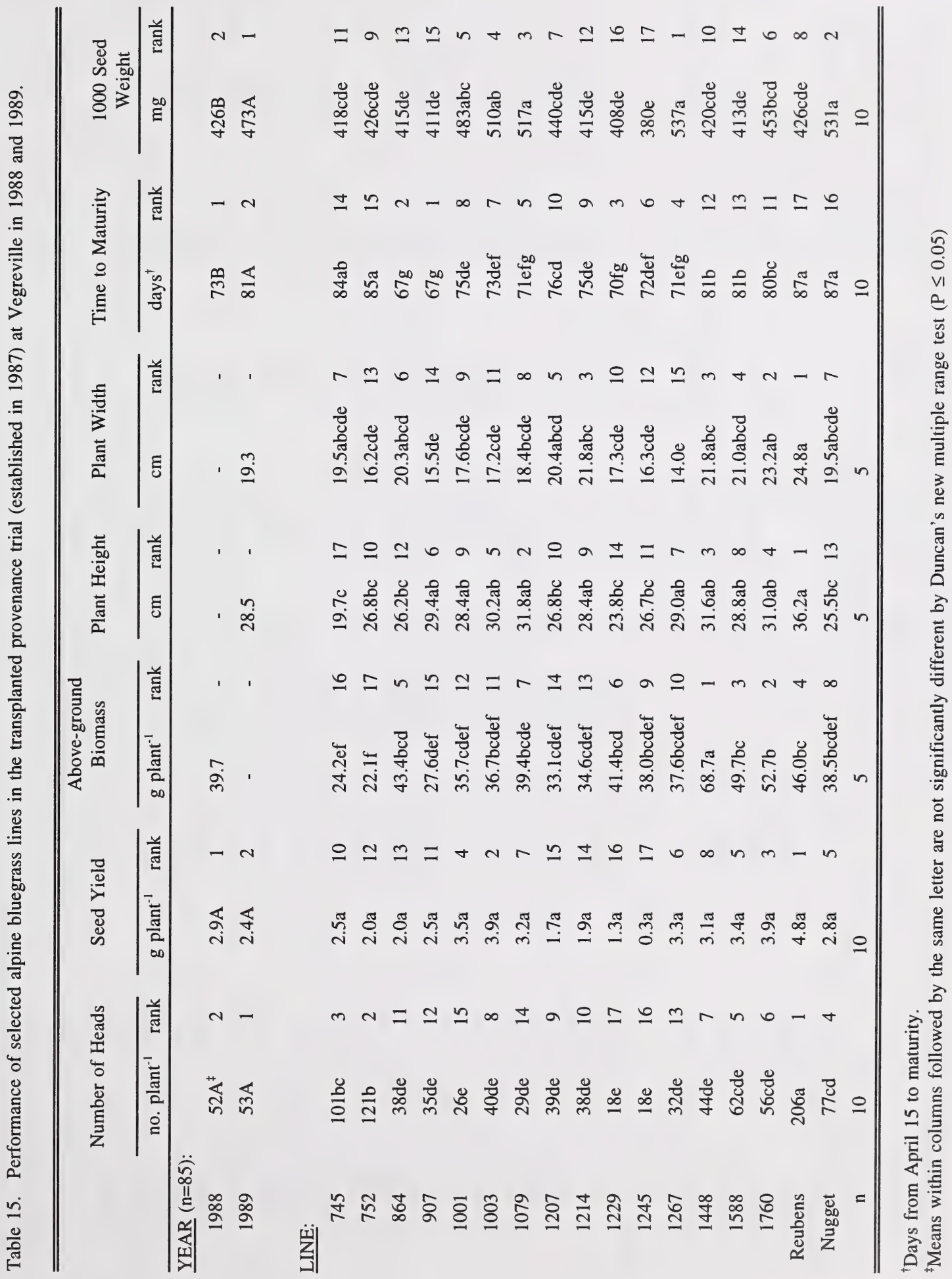




\begin{tabular}{|c|c|}
\hline$f$ & \\
\hline$\cdots$ & 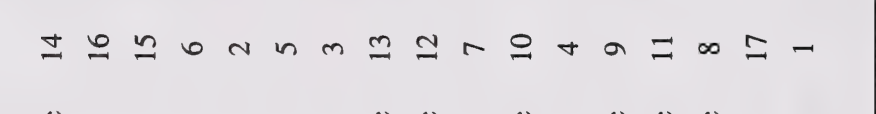 \\
\hline 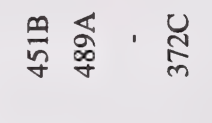 &  \\
\hline$-\cdots$ & 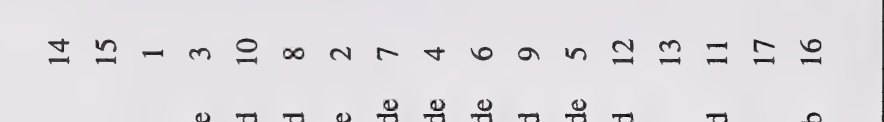 \\
\hline 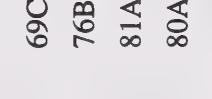 & 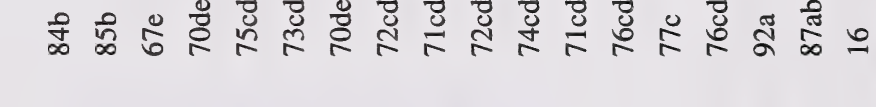 \\
\hline 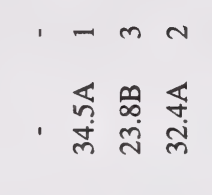 & 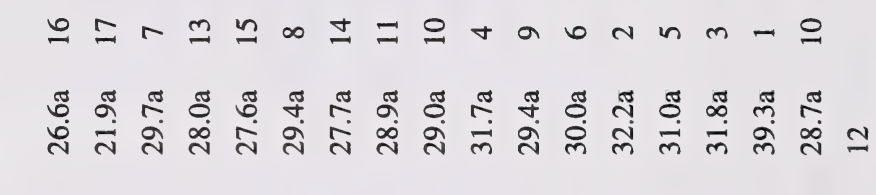 \\
\hline & $=\varrho \pm \simeq \varrho 0 r \cong m=\infty a n \sim m-$ \\
\hline \pm & 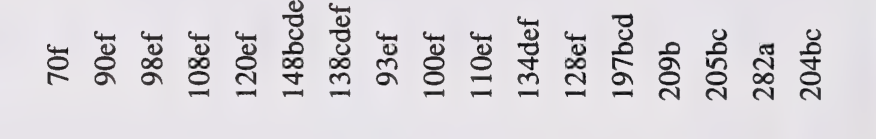 \\
\hline$-n+m$ & 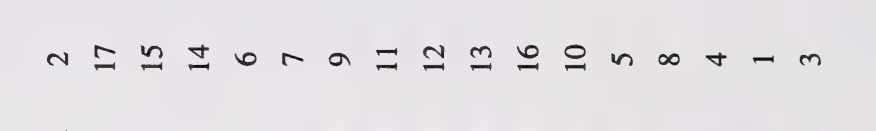 \\
\hline 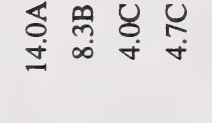 & 美般 \\
\hline$-\infty+$ &  \\
\hline 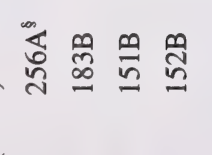 & 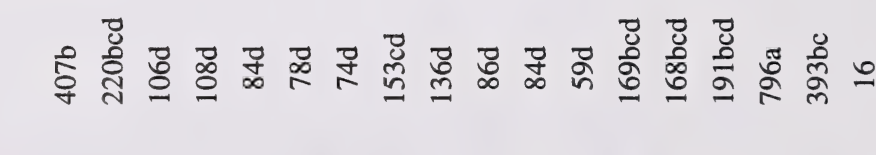 \\
\hline  &  \\
\hline
\end{tabular}



응

$\stackrel{9}{9}$

寻

웡

o

\%

त

궁

홀응 ㅇ. 드

的要

T.

这骂

탕 


\subsubsection{Materials and Methods}

Eight lines of alpine bluegrass, including three mixtures of lines, were selected for final testing in multilocation trials. These selections were based on previous performance in provenance trials. Line mixtures were included for evaluation because it was thought that mixtures would have better general adaptations than single lines. However, because of difficulty in producing breeder seed of line mixtures, it was later decided that only single lines would be released as varieties. The selections included lines $907,1003,1448,1588,1760$, and three line mixtures, M1 (lines 1448, 1588 and 1760), M2 (lines 907, 1003, 1214), and M3 (lines 864, 907, 1079, and 1229). Reubens Canada bluegrass and Nugget Kentucky bluegrass were used as check varieties in all trials.

Multilocation trials were seeded in 1990 and 1991 at Vegreville, Beaverlodge (elevation $730 \mathrm{~m}$ ), Columbia Icefields, and Mountain Park (Fig. 1). A third trial was established at Vegreville and Plamondon (elevation $560 \mathrm{~m}$ ) in 1992 to replace the first trial which did not emerge well at Beaverlodge. Mid- to late May seeding dates were used for the plains sites and late June seeding dates were used at the mountain sites. At plains sites, each plot consisted of five $6 \mathrm{~m}$ rows, with a $40 \mathrm{~cm}$ row spacing. At Columbia Icefields and Mountain Park, each plot consisted of a single $2 \mathrm{~m}$ row with a $1 \mathrm{~m}$ spacing between plots. Plots were seeded with a small plot seeder at the plains sites but were seeded by hand in the mountains. Approximately $500 \mathrm{~g}$ (equivalent to $2500 \mathrm{~kg} \mathrm{ha}^{-1}$ ) of peat moss was incorporated into the soil to a depth of about 30 $\mathrm{cm}$ prior to seeding at the mountain locations. This was done to compensate for the very poor, coarse soils found at these sites. A randomized complete block design with six blocks was used for all trials.

Seed yield was the primary characteristic studied, especially at the plains sites. Plants were harvested by hand and the seed was later threshed and cleaned to determine seed yield. Winter survival, percent cover, plant height, flowering date, number of heads produced, maturity date, and 1000 seed weight were also evaluated where possible. Winter survival and percent cover were estimated visually. Plant height was estimated by measuring three random plants per plot. At plains sites, seed yield was determined by harvesting seed from the three centre rows of each plot. At mountain sites, seed was harvested from the entire plot. Flowering date could 
only be recorded at the Vegreville site because other sites were too far away to keep an accurate record of plant development. Although we originally planned to evaluate the ability of each line to produce viable seed under high elevation conditions, this could not be accomplished due to the small amounts of seed produced at the mountain sites.

Analyses of variance of all data were conducted for each year and for combined analyses over years and locations using the general linear models (GLM) procedure of the SAS statistical package (SAS Institute, Inc. 1990). Mean separation was conducted using Duncan's new multiple range test.

\subsubsection{Results and Discussion}

In multilocation trials at mountain sites, it took at least two years of establishment before alpine bluegrass flowered. At Columbia Icefields, plants in Trial 1 flowered and set seed in 1992 but in 1993, the growing season was cool, wet, and short (see Appendix C) so very few heads were produced (Table 17). In Trial 2, most plants had died by 1994 so no more data were collected. This trial was located in a different part of the site and may have been affected by different soil conditions or different weather conditions (drier) when the plants were seedlings. Mean percent cover in this trial was only $1 \%$ in 1993. In Trial 1, percent cover ranged from only $14 \%$ in 1993 to $68 \%$ in 1992 . Because cover estimates are subjective, some of the variation among years may be due to different people estimating cover values. Lines 1003 (AEC Glacier) and 1760 (AEC Blueridge) had the highest mean cover values. Nugget had the lowest cover with a mean value of only $7 \%$. Lines M3, 1588, and 907 produced the most heads and the most seed. There were no significant differences among lines for seed yield, plant height, or plant width.

At Mountain Park, both trials survived well and seed was harvested from Trial 1 in 1992 to 1994 and from Trial 2 in 1994. Percent cover values ranged from 9.9\% for Trial 2 in 1992 to $37.5 \%$ for Trial 1 in 1994 (Table 18) and were higher than those observed at Columbia Icefields (Table 17). Although Reubens produced more heads than any selected line, it had the second lowest seed yield; only Nugget produced less seed (Table 18). Line 1760 was second in number of heads and first in seed yield. Nugget had the shortest plants and there were no significant differences for plant width.

In the first year of seed production (second year of growth) at plains sites, some winterkill was observed in Trial 1 at Vegreville but all other trials had mean winter survival 
values of $93 \%$ or greater (Table 19). The 1990/91 winter seemed to be more severe than the 1991/92 winter at Vegreville, possibly due to the early arrival of snow in October. First year seed yields ranged from $79 \mathrm{~kg} \mathrm{ha}^{-1}$ in Trial 2 at Beaverlodge, to $688 \mathrm{~kg} \mathrm{ha}^{-1}$ in Trial 3 at Vegreville. The low yields in Trial 2 at Beaverlodge were due to poor emergence. The number of heads produced was lowest at Plamondon and highest in Trial 3 at Vegreville. Line 1003 had the best seed yields (with a mean of $376 \mathrm{~kg} \mathrm{ha}^{-1}$ ), even though it produced the fewest heads. It appears to be more drought tolerant than the other lines and was able to fill more seeds than the other lines under the dry conditions found at most sites in the first year of seed production. Plant height was similar for the selected lines and Nugget, but Reubens was significantly taller. There was a range in time to maturity among alpine bluegrass lines with line 907 maturing first (at 71 days after April 15) and line 1760 maturing last (82 days). On average, Nugget matured 12 days after line 1760 and Reubens matured 8 days after Nugget. Nugget produced the heaviest seeds while Reubens produced the smallest seeds.

Winter survival was reduced in Trial 1 at Vegreville and at Beaverlodge in the second year of seed production (Table 20). At Vegreville, seed yields were generally lower in the second year of seed production than in the first year (Table 19). However, at Beaverlodge and Plamondon, improved moisture conditions led to increased seed yields in the second year (Table 20). Number of heads produced was lowest at Beaverlodge but it still produced the highest mean seed yield. Line 1003 once again had the highest seed yields although it only ranked eighth in number of heads. Of the single lines of alpine bluegrass, line 1760 ranked second in seed yield with a higher yield than Nugget but lower yield than Reubens. Reubens had the tallest plants and line 907 had the shortest. Reubens and Nugget had the widest plants, due to their rhizomatous growth habit. Line 907 matured first and Reubens matured last, as in the first year of seed production. Seed weights were similar for all lines and Nugget, but Reubens had significantly smaller seeds.

Only one trial was maintained to the third year of seed production, Trial 2 at Vegreville. All lines had good winter survival except line 907 which had a mean survival of only $72 \%$ (Table 21). Reubens with its rhizomatous nature, produced far more heads than any line but it ranked only eighth in seed yield. As in other years, line 1003 had the highest seed yield. Overall, mean seed yields were lower than those observed in previous years. Plants of Reubens 
were much taller than plants of all other lines. Line 907 matured first and Reubens and Nugget matured last. As before, Nugget had the largest seeds and Reubens had the smallest.

Of the single lines, line 1003 clearly outperformed all lines and the check varieties at the plains sites. This line was released as AEC Glacier alpine bluegrass. At mountain sites, there was no clear indication of the best line but line 1760 did perform well in the multilocation trials and in the provenance trials. It also did well at the plains sites. Line 1760 was released as AEC Blueridge alpine bluegrass.

In our breeder seed plots, which were harvested with a combine as opposed to hand harvesting in small plot trials, average seed yield for AEC Blueridge alpine bluegrass was $66 \mathrm{~kg} \mathrm{ha}^{-1}$. For AEC Glacier, only one seed harvest has been made so far and it yielded only $5 \mathrm{~kg} \mathrm{ha}^{-1}$. This was due to some winterkill on that plot. Seed yields for AEC Glacier are expected to be much higher in 1995 as that plot has recovered and has produced many more seed heads. Lower seed yields on breeder seed plots, as compared to small plots, are expected due to some shattering losses during combining. Yields observed on breeder seed plots will more closely approximate those to be expected on larger seed fields of these varieties. 


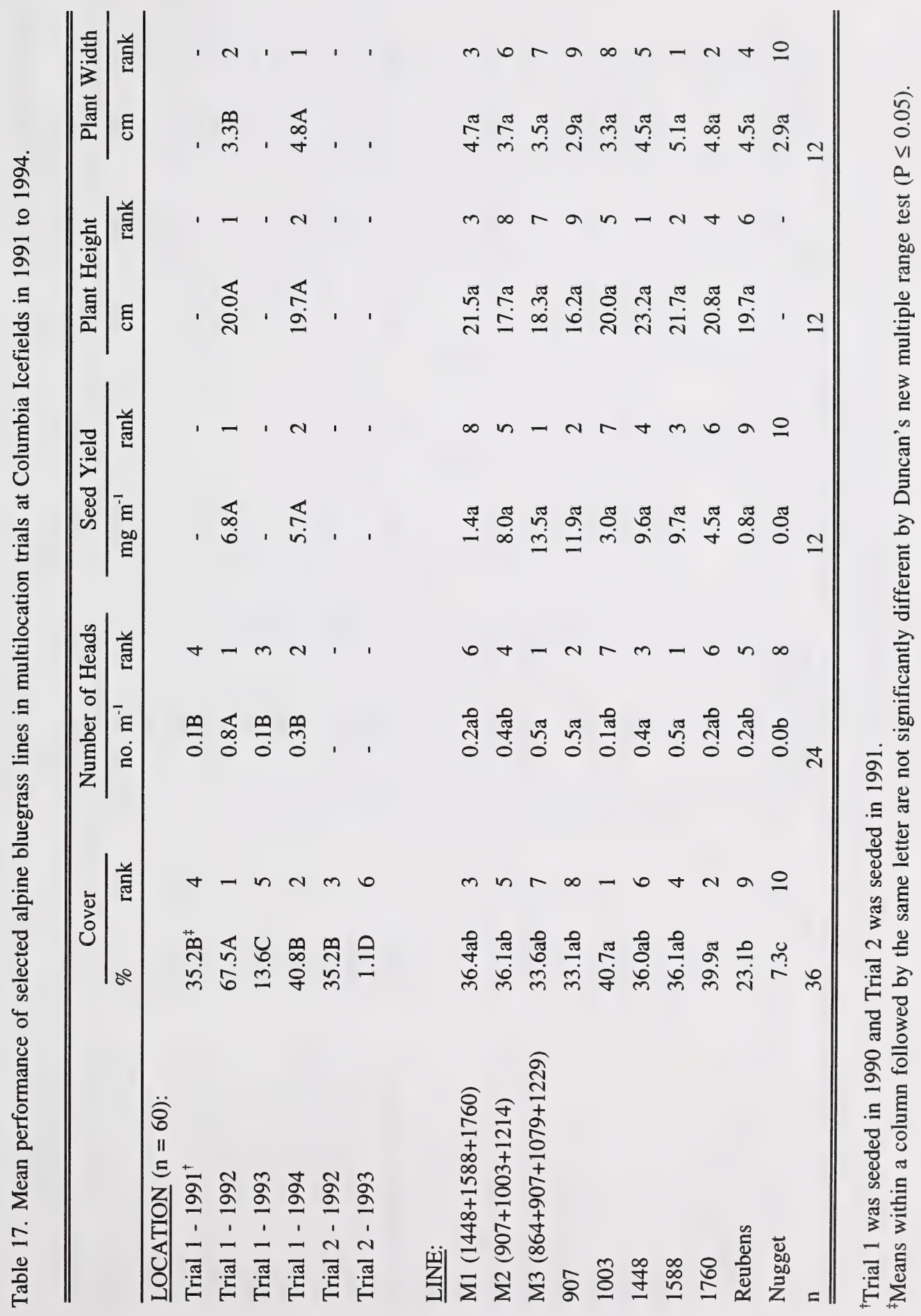




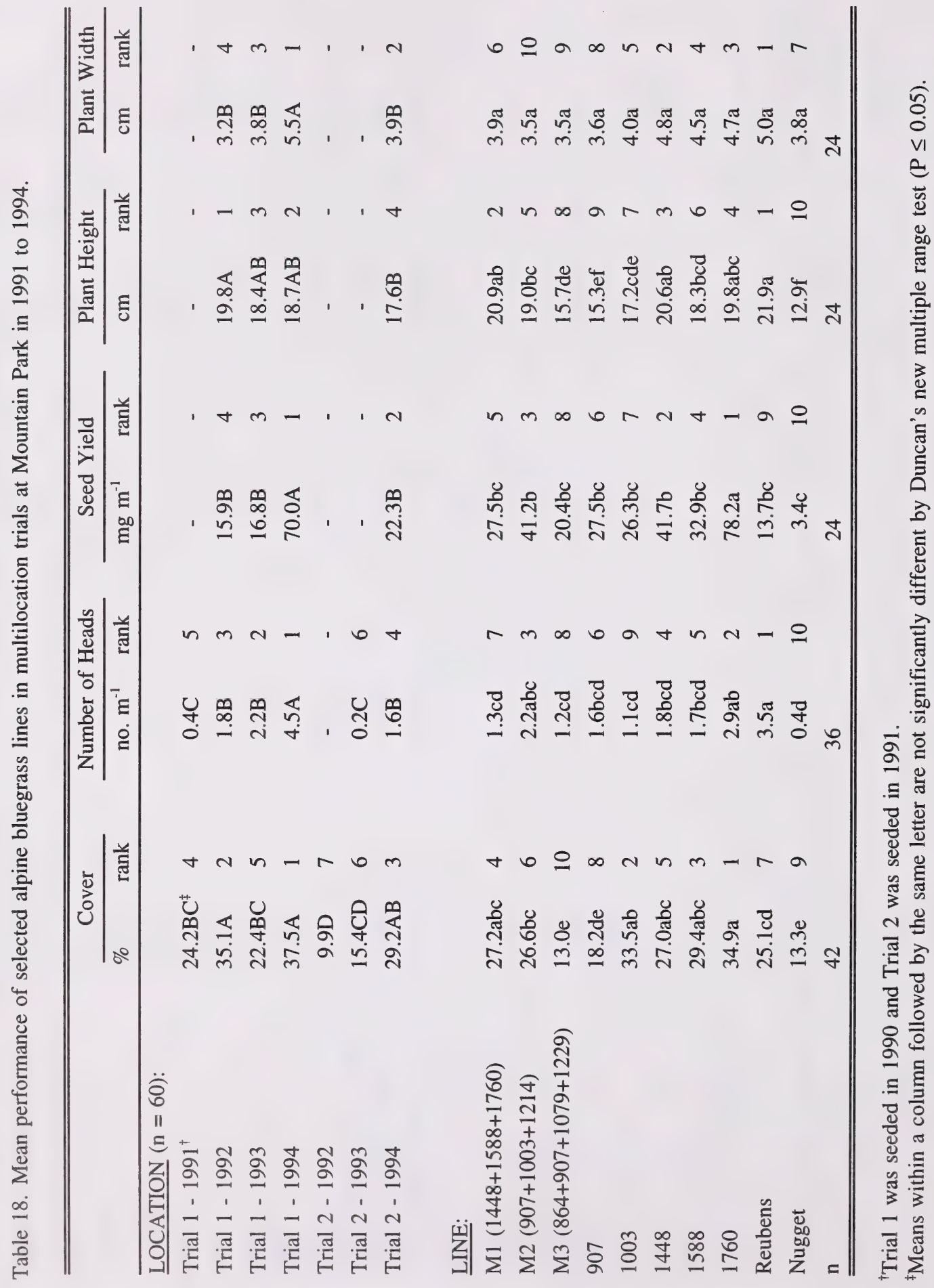




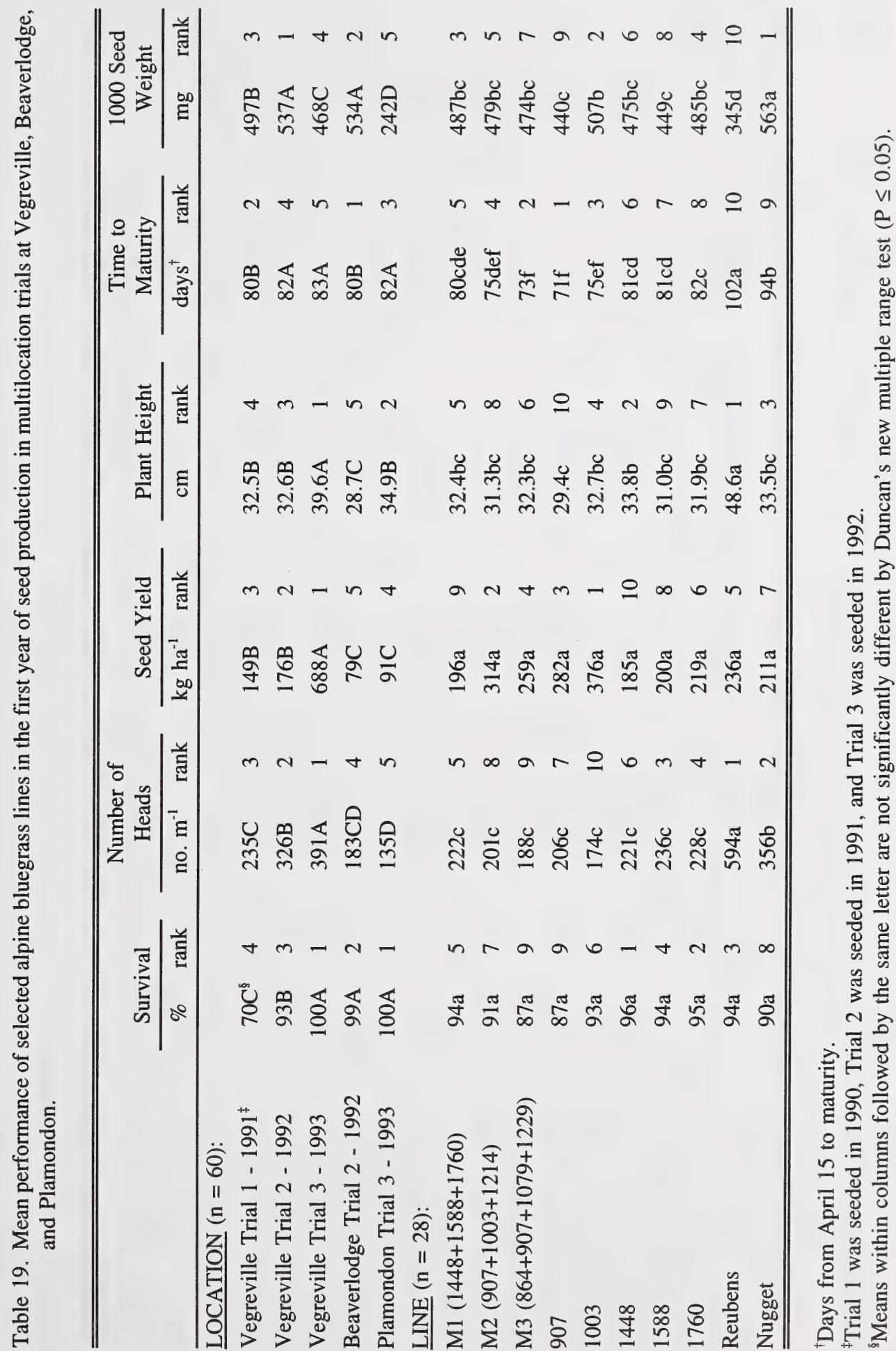









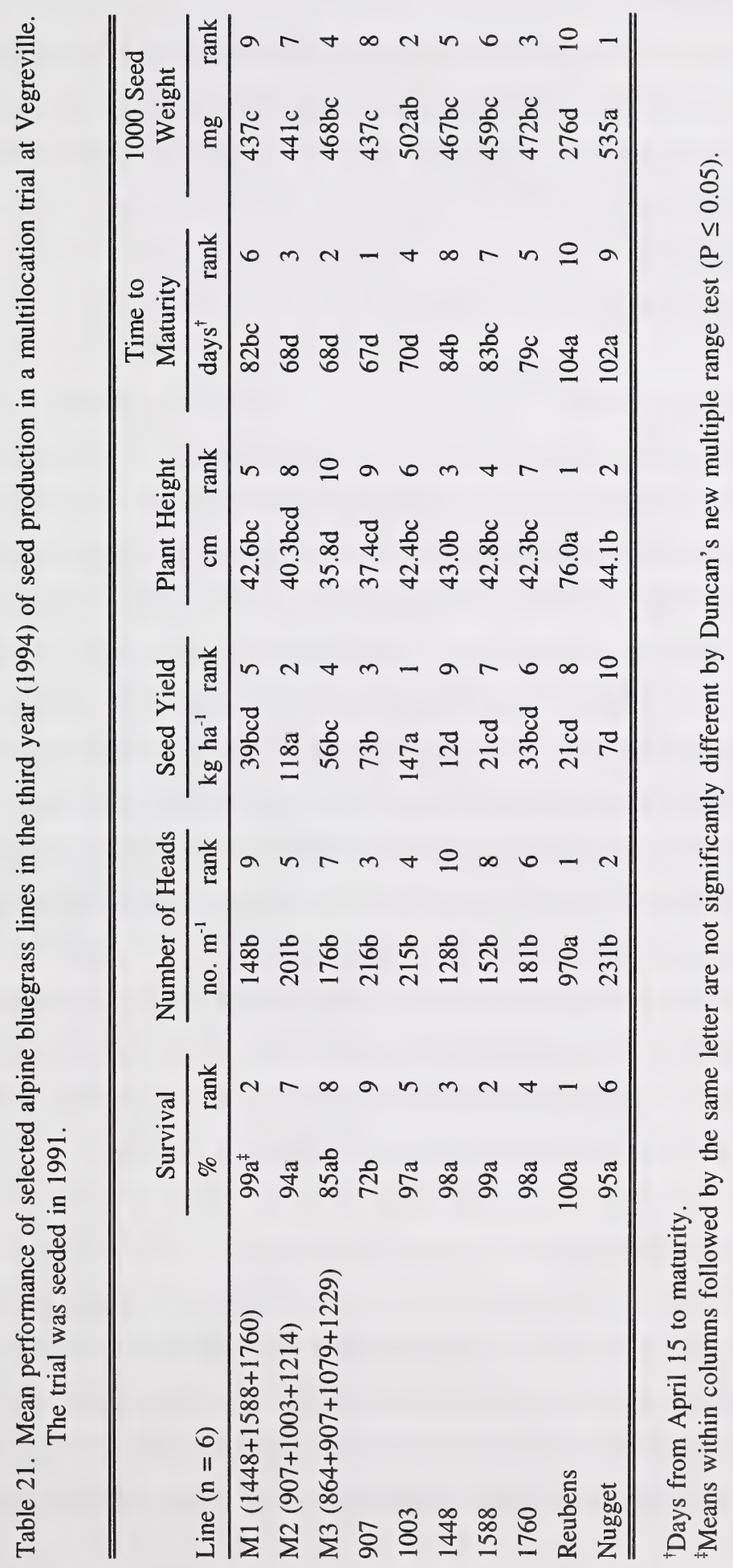




\section{AGRONOMY}

Unless otherwise indicated, the agronomic practices recommended are suitable for large scale seed production of these alpine bluegrass varieties. Because these varieties were developed for reclamation use, agronomic recommendations for forage and pasture use have not been developed.

\section{$4.1 \quad$ Seeding}

\subsubsection{Materials and Methods}

To evaluate the effect of seeding date on establishment, growth, and yield of alpine bluegrass, trials were seeded at Vegreville in 1991, 1992, and 1993. Trial 1 emerged well but was almost completely winterkilled in the first winter. Therefore, no data were taken from that trial and a third trial was seeded in 1993 to replace it. Alpine bluegrass lines 907 and 1760 (AEC Blueridge) were used in these trials. Four seeding dates were tested: second or third week of May, third or fourth week of June, fourth week of August and the second or third week of October. The trials were set up in randomized complete block designs with four blocks (replicates). A factorial arrangement of treatments was used. Emergence, percent cover, percent winter survival, number of heads produced, seed yield, time to maturity, and plant height were determined for each plot. Data were analyzed using the general linear models procedure of the SAS statistical package (SAS Institute, Inc. 1990).

For other aspects of seeding techniques, much of the information presented was gained through experience in seeding small plots and larger seed increase plots at Vegreville. Although no experiments were conducted to examine alternatives, these techniques represent what has worked well for us and should be applicable to larger field situations.

\subsubsection{Results and Discussion}

The results of these seeding date trials indicated that alpine bluegrass should be seeded in May. Delaying seeding until June or later resulted in very poor establishment and little or no seed yield in the first year of seed production (Table 22). May seeding gave the best emergence, the best cover, the highest number of heads and the highest seed yield. Plants seeded in May were also tallest but there was no effect on time to maturity. Plants seeded in August or October 
did not flower in the first year of seed production. We expected that the October seeded plants would not flower because alpine bluegrass needs one growing season for establishment before seed production. Plants seeded in October did not emerge until the following year so they were in their establishment year while other plants were in the first seed production year. Plants seeded in August did emerge in the year they were seeded but were not large enough to initiate the development of heads. The two alpine bluegrass lines were not significantly different for all data recorded except winter survival where line 1760 survived better than line 907. Previous experience with line 907 has shown that it tends to more susceptible to winterkill than most of the other selected alpine bluegrass lines.

In the second year of seed production, both the May and August seeding dates had good cover values but May-seeded plants still produced the best seed yields (Table 23). Winter survival, number of heads and time to maturity were not significantly affected by time of seeding. Line 1760 matured later than line 907 and had taller plants but otherwise the two lines performed similarly.

When seeding alpine bluegrass, a seeding depth of $1 \mathrm{~cm}$ or less gives the best results. A row spacing of 20 to $40 \mathrm{~cm}$ is recommended, although for pedigreed seed production, the wider row spacing allows for easier access to remove any off-types. A seeding rate of 2 to $4 \mathrm{~kg} \mathrm{ha}^{-1}$ may be used, with lower seeding rates for more widely spaced rows.

Conventional seed drills are generally acceptable as long as the depth can be adequately controlled. Alpine bluegrass seed must be mixed with an inert material such as cracked wheat to prevent the seed from bridging in the seeder. Specialized native seed drills with agitators that help prevent bridging may also be useful (Joyce 1993). In some situations, broadcast seeding followed by raking or harrowing may also be acceptable but better results are generally obtained by using seed drills. When broadcasting the seed, use a higher seeding rate.

We do not recommend the application of any fertilizer with the seeding operation. We seed into summerfallow so plant nutrients are generally not lacking. These varieties are adapted to low nutrient situations and the application of fertilizer does not seem to enhance their growth or seed yields. Previous experiments have shown no significant advantage to the use of fertilizer, although these experiments were conducted on summerfallow where soil nutrients may not have been limiting. Lack of response to fertilizer may also be due to the origin of these varieties. They have been derived from plants collected from relatively infertile soils. Such plants are 
adapted to low nutrient conditions, and unlike species from high-nutrient environments, they do not respond to additional nutrient inputs (Chapin 1980).

Finally, the most important seeding technique is to be sure to seed into a clean seedbed. Alpine bluegrass is not highly competitive so weeds can provide strong competition and weed control is difficult because no herbicides are registered for use on alpine bluegrass. It is also very important to seed these varieties without a companion crop. Use of a companion crop would delay seed production by an extra year and would severely reduce seed yields.

\subsection{Pest Management}

Alpine bluegrass can be affected by weeds, insects, and diseases, but the most troublesome problems are created by weeds because of the non-competitive nature of this species. In an attempt to overcome some of the weed problems, an experiment was set up to screen alpine bluegrass seedlings for tolerance to various herbicides. Management techniques for diseases and insects, although less important, have been developed through experience when growing small plot trials and large seed increase plots of these varieties.

\subsubsection{Weed Control}

\subsubsection{Materials and Methods}

To investigate the tolerance of alpine bluegrass to various herbicides, an indoor experiment was established in 1991. A second, smaller experiment, was set up in 1993. In 1991 the herbicides studied included: bromoxynil/MCPA ester $\left(\right.$ Buctril $\left.\mathbf{M}^{\circledR}\right)$, dicamba $\left(\right.$ Banvel $\left.^{\circledR}\right)$, clopyralid $\left(\right.$ Lontrel $^{\circledR}$ ), clopyralid plus 2,4-D ester, clopyralid plus MCPA ester, diclofopmethyl/bromoxynil (Hoegrass II ${ }^{\circledR}$ ), fenoxaprop-ethyl plus MCPA ester plus thifensulfuron methyl (Triumph Plus ${ }^{\circledR}$ ), chlorsulfuron $\left(\right.$ Glean $\left.^{\circledR}\right)$, 2,4-D/mecoprop/dicamba (Trimex ${ }^{\circledR}$ ), and linuron $\left(\right.$ Lorox $\mathrm{DF}^{\circledR}$ ). Since undertaking this experiment, Glean has been deregistered for use on crops. In the 1993 experiment, the following additional herbicides were tested: tralkoxydim (Achieve ${ }^{\circledR}$ ) plus bromoxynil/MCPA ester (Buctril $\mathbf{M}^{\circledR}$ ) plus Charge ${ }^{\circledR}$, bentazon $\left(\right.$ Basagran $^{\circledR}$ ) plus Assist ${ }^{\circledR}$, tribenuron methyl $\left(\right.$ Express $^{\circledR}$ ) plus 2,4-D ester, fenoxaprop-p-ethyl/bromoxynil/MCPA ester $\left(\right.$ Laser $\left.^{\circledR}\right)$, and fenoxaprop-p-ethyl/MCPA ester plus thifensulfuron (Laser DF ${ }^{\circledR}$ ). All application rates used in these experiments were based on the recommended rates for forage grass crops 
listed in the Guide to Crop Protection in Alberta (Ali 1991; Ali 1993) or the rates listed on the herbicide label.

Alpine bluegrass seedlings were grown in small trays with 10 plants per tray. Greenhouse conditions were set at $22 / 15^{\circ} \mathrm{C}$ for day/night temperatures with a 16 hour photoperiod. Herbicides were applied at the 2-leaf and 5-leaf growth stages, using a cabinet sprayer (RIC Spray Chamber, Research Instrument Manufacturing Co. Ltd, Guelph). The sprayer was equipped with an 8001 flat fan nozzle at $275 \mathrm{kpa}$ and $3 \mathrm{~km} \mathrm{~h}^{-1}$, which is similar to that used in a field sprayer. A randomized complete block design with a factorial arrangement of herbicide treatment and leaf stage was used.

Following spraying, plants were fertilized every two weeks with a 20-20-20 fertilizer solution. These fertilizer applications were used to ensure that observed plant responses were not related to nutrient deficiencies due to the limited amount of soil available in each tray. Seedlings were scored for tolerance to herbicides 1,5 , and 8 wk after herbicide application. A scale of 0 to 9 (as adopted by the Expert Committee on Weeds, 1979) was used; 0 being no tolerance (plant death) and 9 being complete tolerance. Top growth of the plants was harvested after $8 \mathrm{wk}$ and biomass dry weight was recorded. Data were analyzed using the general linear models procedure of SAS (SAS Institute, Inc. 1990) and treatment means were compared to the control using Dunnett's test. A one-sided test was used for score means and a two-sided test was used for biomass means.

\subsubsection{Results and Discussion}

In the first herbicide tolerance trial on potted seedlings of alpine bluegrass, all herbicide treatments except linuron caused a significant decrease in score values one week after treatment at the 2-leaf stage (Table 24). By $8 \mathrm{wk}$, many treatments had recovered such that above-ground biomass was significantly lower than the control in only five treatments: dicamba (at the highest rate), diclofop-methyl/bromoxynil, chlorsulfuron (at the two rates tested), and 2,4$\mathrm{D} /$ mecoprop/dicamba. The plants treated with linuron had significantly higher biomass than the control. When herbicides were applied at the 5-leaf stage, 11 of the 14 herbicide treatments significantly affected plant score after $1 \mathrm{wk}$, but by the time above-ground biomass was determined at $8 \mathrm{wk}$, no treatments were significantly different from the control. 
In the second herbicide trial, two herbicide treatments caused a significant decrease in plant scores and above-ground biomass when applied at the 2-leaf stage (Table 25). These treatments were tralkoxydim plus bromoxynil/MCPA ester plus Charge and fenoxaprop-pethyl/MCPA ester plus thifensulfuron. Alpine bluegrass seedlings were damaged when sprayed with fenoxaprop-p-ethyl/bromoxynil/MCPA ester at the 2-leaf stage but they later recovered. When plants were sprayed at the five leaf stage there was little effect on plant score but three treatments (tribenuron methyl plus 2,4-D ester, fenoxaprop-p-ethyl/bromoxynil/MCPA ester, and fenoxaprop-p-ethyl/MCPA ester plus thifensulfuron) had significantly lower biomass than the highest value.

These two experiments have indicated possible useful herbicides for weed control in alpine bluegrass, but were conducted indoors on seedlings. Therefore, we do not know what effects these herbicides may have on plants grown under field conditions or on seed yield of alpine bluegrass. Currently, there are no selective herbicides registered for use in alpine bluegrass (Ali 1995). However, spot spraying with glyphosate (eg. Roundup ${ }^{\circledR}$ ) can be useful for control of such weeds as quackgrass (Elytrigia repens) and Canada thistle (Cirsium arvense). These primary noxious weeds can cause problems in seed fields and it is best to avoid these weeds by seeding into a clean seedbed. Preplant applications of glyphosate can also help to control these weeds.

\subsubsection{Control of Plant Diseases and Insects}

In addition to problems with weeds, alpine bluegrass is susceptible to plant diseases such as powdery mildew (Erysiphe graminis) and leaf rust (Puccinia graminis) (Martens et al. 1984). In many cases, however, these diseases do not appear until the seed is almost mature or after harvest. They have little effect on seed yield although they may affect plant vigour and therefore seed yield in the following year. Although there are effective fungicides available for controlling powdery mildew and rusts in turfgrass, they are not registered for use in Canada (Martens et al. 1984). Alpine bluegrass may be susceptible to snow mould (Hardy BBT Ltd. 1989) and leaf spot diseases (Martens et al. 1984) but we have not observed any major problems with this disease. We have observed silvertop (or whiteheads) in our seed production plots of alpine bluegrass. The cause of silvertop is uncertain, and it is more common in some years than others. There are no control measures for silvertop in alpine bluegrass. 
In our experience, alpine bluegrass has few problems with insect infestations in the field. In some years, however, infestations of spider mites can reduce plant vigour and subsequent seed yields. Fenbutatin oxide $\left(\right.$ Vendex $\left.{ }^{\circledR}\right)$ is registered for control of mites in ornamental and nursery crops. There may also be problems with insects such as grasshoppers, cutworms, and wireworms that commonly infest crops (Bolton ca. 1985), but we have not observed any large infestations of these insects.

\section{$4.3 \quad$ Harvesting}

Harvesting alpine bluegrass begins in late June. AEC Glacier alpine bluegrass is generally ripe by the last week of June. AEC Blueridge matures later, by the second week of July. In most years, alpine bluegrass will produce a second flush of heads later in the summer but these are too thin to harvest. These late-season heads should be mowed off soon after anthesis so the plants do not expend too much energy to fill the seed.

Alpine bluegrass is highly subject to shattering, more so than other bluegrass species. Direct combining is recommended where possible. Plants should be harvested when the stems and heads are golden and it is possible to remove some seeds from the heads by gently shaking the seed head against the palm of your hand. Seed should be less than $30 \%$ moisture when direct combining. We do not recommend swathing before combining because the crop is too short to make a good swath. If swathing is the only alternative, swath in the medium to firm dough stage when seed head moisture content is 45 to $50 \%$ (Bolton ca. 1985). The seed heads should be placed in the centre of the swath to help keep shattered seeds on top of the swath. Greater shattering losses can occur if the crop is swathed too close to maturity. Losses can be reduced by swathing in early morning or late evening when humidity is higher. Shattering can also be a problem with direct combining. When combining, a high cylinder speed (1200 to $1400 \mathrm{rpm}$ ) and a concave spacing of about $6 \mathrm{~mm}$ is recommended (Najda et al. 1994). Use little or no wind over the cleaning shoe. In harvesting other bluegrasses, some seed growers have had success with rotary or axial flow combines (Najda et al. 1994).

Following harvest, all seed must be dried using aeration with or without heat (maximum air temperature of $38^{\circ} \mathrm{C}$; Najda et al. 1994). This is especially true for seed that has been directcombined because it will generally have a higher moister content. It is best to dry the seed to a moisture content of 10 to $12 \%$ for long term storage. Seed cleaning can be completed in most 
seed cleaning plants. Use as little wind as possible when cleaning to minimize the amount of seed lost.

\subsection{Post-Harvest Management}

After harvesting, the fields are often mowed to remove any remaining stems. This won't be necessary if the swather or combine cuts low enough. After mowing, the straw is baled and removed from the field. Removing harvest residue from the seed field reduces disease problems and increases light penetration, which stimulates the plants to produce more tillers (Najda et al. 1994). If the alpine bluegrass plants produce more seed heads after harvest, these are mowed while still green. In Kentucky and Canada bluegrass seed fields, burning the field in the spring to reduce the effects of disease and insects is recommended (Bolton ca. 1985).

Even with good management, alpine bluegrass stands will survive for only four to five years on the plains. The use of nitrogen fertilizer to extend the life of the stand has been recommended for other bluegrasses (Bolton ca. 1985). However, past experiments on alpine bluegrass showed no response to nitrogen fertilizer application. 


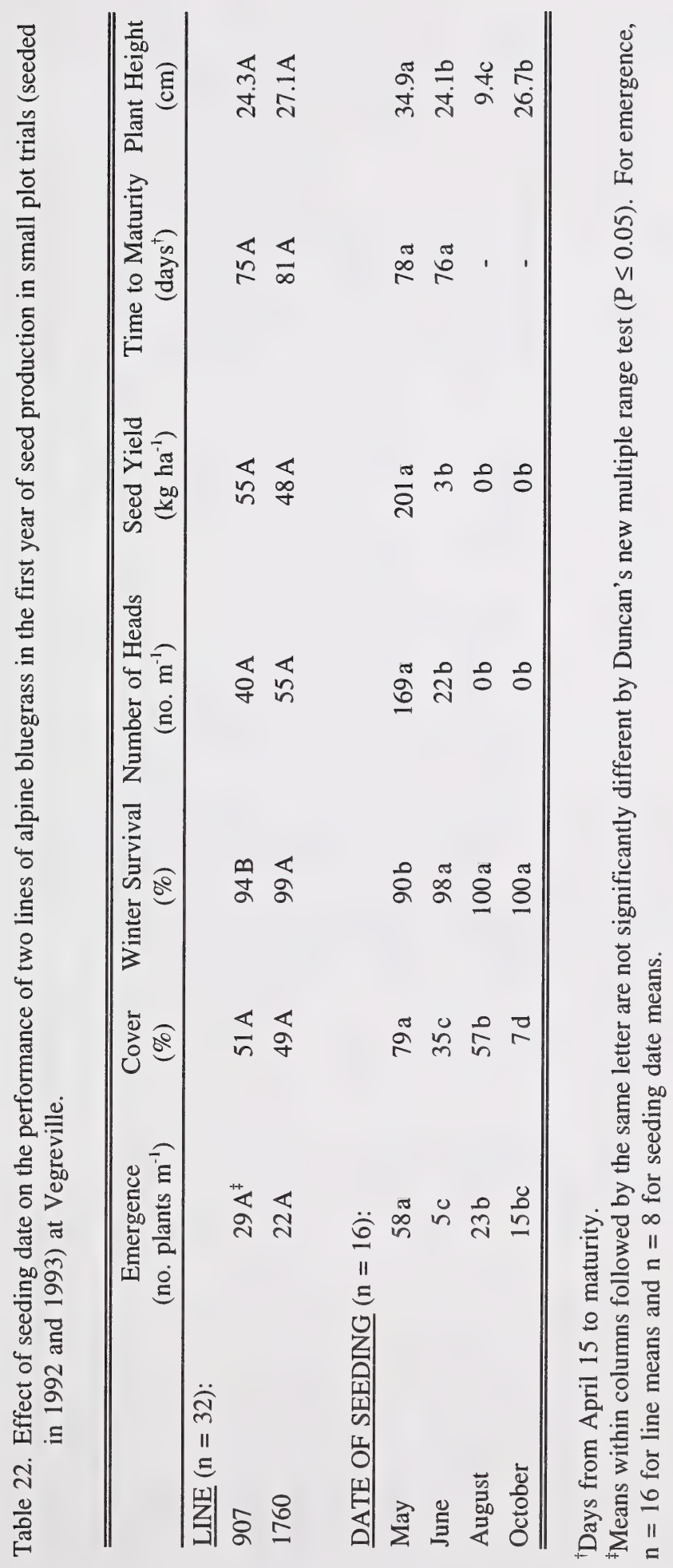




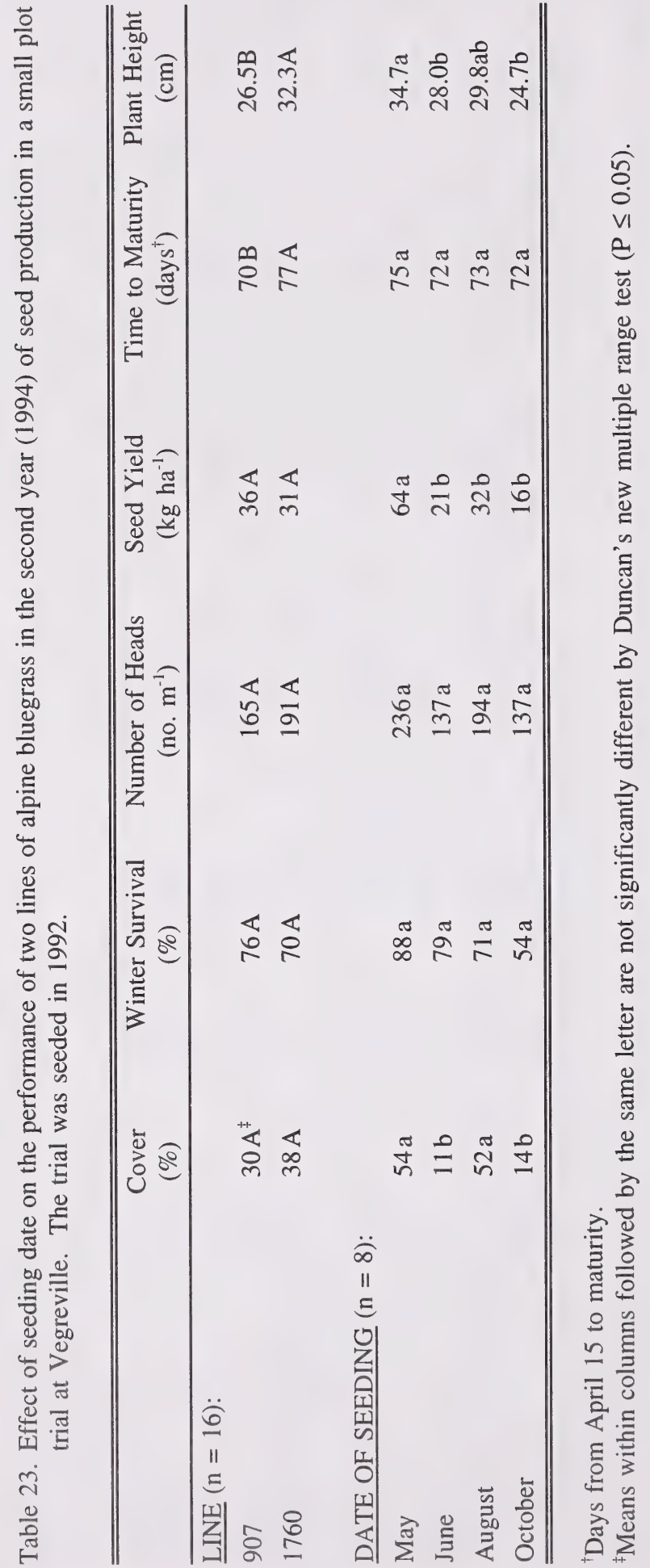








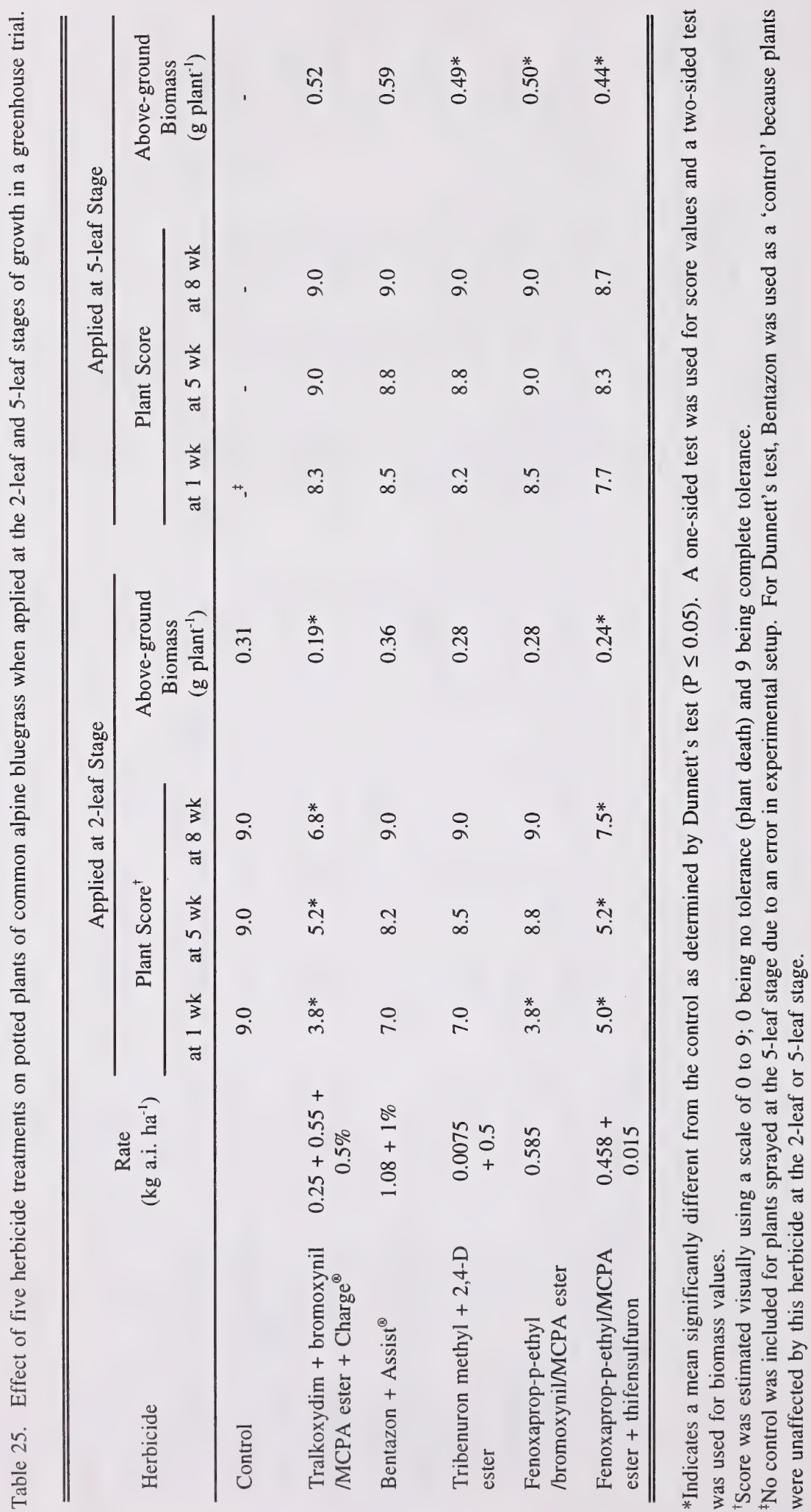
Disturbed sites at high elevations provide very harsh environments for plant establishment and growth. Revegetating such sites requires the development of techniques specifically suited to overcome such problems as short growing seasons, moisture stress, and shallow, infertile soils. Selection of species and varieties adapted to these conditions can help to overcome these problems. Techniques used for establishing native plants are also important. Brown et al. (1976) recommended that alpine disturbances be seeded in late fall. However, no data were presented to support this recommendation. Fall seeding mimics natural seeding because most native plants drop their seed by fall. Fall seeding also ensures that the seed can take full advantage of the moisture available after snowmelt in the spring. The use of soil amendments and fertilizers to improve plant stands for reclamation has also been investigated with varying results. More research is required to determine appropriate methods for establishment and maintenance of alpine bluegrass when grown for reclaiming disturbed sites at high elevations.

\subsection{Species/Variety Selection}

Adaptation is important when selecting plant species and varieties within species for reclaiming and revegetating a disturbed site. By choosing species/varieties that are adapted to the conditions found at a particular site, the chances of successful revegetation are greatly improved (Thornburg 1982; Brown and Chambers 1989). The short growing seasons characteristic of high elevations limit the number of plant species that can be successfully grown at such sites.

Alpine bluegrass is adapted to alpine and subalpine regions (Moss 1983) and is common on dry and moist slopes, meadows, and rocky areas (Hardy BBT Ltd. 1989). It is a good candidate for revegetation in alpine areas (Hardy BBT Ltd. 1990) because it is an active colonizer species on virtually all disturbed sites in alpine environments including bare soils, acidic mine spoils, talus slopes, and alluvial sites (Hardy BBT Ltd. 1989). Alpine bluegrass is rated high for palatability and is grazed by both domestic animals and wildlife. Its high root:shoot ratio is important for soil building but it is not very effective for control of surface runoff. Alpine bluegrass is less susceptible to trampling than other alpine species and has been observed to thrive on trampled soil. 
AEC Blueridge alpine bluegrass is adapted to elevations as high as $2500 \mathrm{~m}$. AEC Glacier is also adapted to high elevations, but seems to do better at slightly lower elevations, up to $2400 \mathrm{~m}$. Observations made in field trials at plains sites indicate that AEC Glacier is more drought tolerant than AEC Blueridge. Although these varieties are pure lines, they were developed to be included in mixtures of several species/varieties and were not intended to be seeded in monoculture on reclaimed sites.

When reclaiming a disturbed site, we recommend that a mixture of native plant species and varieties (when available) be used. A seed mixture is likely to contain species adapted to the many different microsites found at one reclamation site. Alpine bluegrass makes a good addition to any mixture because it has good establishment and grows well on a wide range of soils. Because of its non-competitive nature, alpine bluegrass will allow other native plant species from surrounding undisturbed areas to invade a reclaimed site. This will help to create a more natural plant community.

\subsection{Seeding, Establishment, and Stand Maintenance}

\subsubsection{Materials and Methods}

An experiment was designed to evaluate the time of seeding (fall versus spring) and the use of peat moss on emergence, growth, and reproduction of common alpine bluegrass under reclamation conditions at high elevations. Trials were established at Columbia Icefields (elevation $1860 \mathrm{~m}$ ) and Mountain Park (elevation $1800 \mathrm{~m}$ ) at sites with little or no topsoil. A randomized complete block design with factorial arrangement of seeding date and soil amendment (peat moss versus no peat moss) was used. Each trial consisted of three replicates. Trial 1 was seeded in September 1990 and June 1991. Trial 2 was seeded in September 1991 and June 1992. For plots receiving the peat moss treatment, approximately $500 \mathrm{~g}$ of peat moss (equivalent to $2500 \mathrm{~kg} \mathrm{ha}^{-1}$ ) were added and incorporated to a depth of about $30 \mathrm{~cm}$. Data on plant emergence and percent cover were recorded and analyzed using the general linear models procedure of SAS (SAS Institute Inc. 1990). For plots at Mountain Park, where plants flowered, data on number of heads, seed yield, plant height, and plant width were also recorded.

A small trial to examine fall versus spring seeding of alpine bluegrass was also established at Columbia Icefields in September 1989 and June 1990. A randomized complete 
block design with three replicates was used for this trial but no peat moss amendments were included. Emergence and percent cover data were recorded and analyzed using SAS.

\subsubsection{Results and Discussion}

At Columbia Icefields, seeding alpine bluegrass in the fall improved emergence compared to seeding in the spring (Table 26). However, at Mountain Park, seeding date had no effect on emergence. Percent cover at both sites was unaffected by seeding date. Similar results were obtained in an earlier trial at Columbia Icefields where seeding date did not affect emergence or cover (Table 27). Although cover was unaffected by seeding date, plants seeded in fall at Mountain Park, produced more seed heads and higher seed yields than those seeded in spring (Table 26). This supports the recommendation of Brown et al. (1976) to seed alpine disturbances in the fall.

The use of peat moss clearly improved emergence and plant cover of alpine bluegrass in our trials at Columbia Icefields and Mountain Park (Table 26). Number of heads and seed yield at Mountain Park also increased with the addition of peat moss. Soils at both sites were very poor and soil nutrient analyses indicated that there was no nitrogen available for plant growth. The application of peat moss not only provided a source of nutrients but it also helped to alleviate some of the physical problems of the soil. At Columbia Icefields especially, the soil forms a very hard crust when dry, thus impeding the emergence of grass seedlings. The addition of peat moss to the soil improved soil conditions, reducing the crusting and cementation problem. Brown et al. (1978) also reported that applications of organic matter such as peat moss, manure, or straw (at rates of 2000 to $4000 \mathrm{~kg} \mathrm{ha}^{-1}$ ) greatly enhanced plant growth and development at high elevation reclamation sites. The addition of topsoil or mulches, if available, is also desirable (Brown et al. 1976; Takyi 1984; Ziemkiewicz 1984; Hardy BBT Ltd. 1990).

When seeding alpine bluegrass at reclamation sites, it is important to seed shallowly (no more than $1 \mathrm{~cm}$ deep). Site preparation should include removing any weeds because alpine bluegrass is not highly competitive. Loosening the soil surface by ripping, rototilling, harrowing, or raking is also beneficial (Brown et al. 1976; Hardy BBT Ltd. 1990). If the site is easily accessible, it may be possible to use conventional farm seed drills (an inert carrier such as cracked wheat must be added to the seed to improve seed flow). In most cases, however, it will be necessary to broadcast the seed either by hand or by using equipment mounted on all terrain 
vehicles. Hydroseeding is another useful alternative if the equipment is available (Hardy BBT Ltd. 1990). Raking or harrowing the seed after broadcasting is necessary to facilitate contact between the seed and soil. When broadcasting the seed, it is necessary to double the seeding rate of that recommended for seed drills (Thornburg 1982) so seeding rates should be approximately 4 to $8 \mathrm{~kg} \mathrm{ha}^{-1}$.

Some researchers (Brown et al. 1976, 1978; Brown and Chambers 1989) recommend the use of fertilizers at the time of seeding, although large quantities and repeated yearly applications may not be necessary (Brown et al. 1984). High rates of fertilization may favour species adapted to high nutrient conditions and reduce the rates of natural colonization and succession (Chapin 1980; Brown and Chambers 1989). Fertilizers may also encourage the growth of weeds (Thornburg 1982) and other non-native species. Therefore, we do not recommend the use of fertilizer when seeding alpine bluegrass at reclamation sites. Instead, the addition of topsoil (Ziemkiewicz 1984) and mulches (Takyi 1984) has been shown to improve establishment of native grasses on abandoned mine sites in Alberta.

Once plants are established, repeated applications of fertilizer may be necessary to maintain an adequate stand of native plants (Brown et al. 1978; Reeder and McGinnies 1989). In contrast, Schuman et al. (1991) reported that a single large application of nitrogen fertilizer can be used to supply adequate nitrogen for the revegetated plant community. With repeated applications, a sharp decline in site productivity occurs when fertilizer applications are discontinued (Brown and Chambers 1989). To avoid this decline, it may be better to use little or no fertilizer or only organic soil amendments (such as peat moss) so that native plant populations are allowed to build up slowly. 


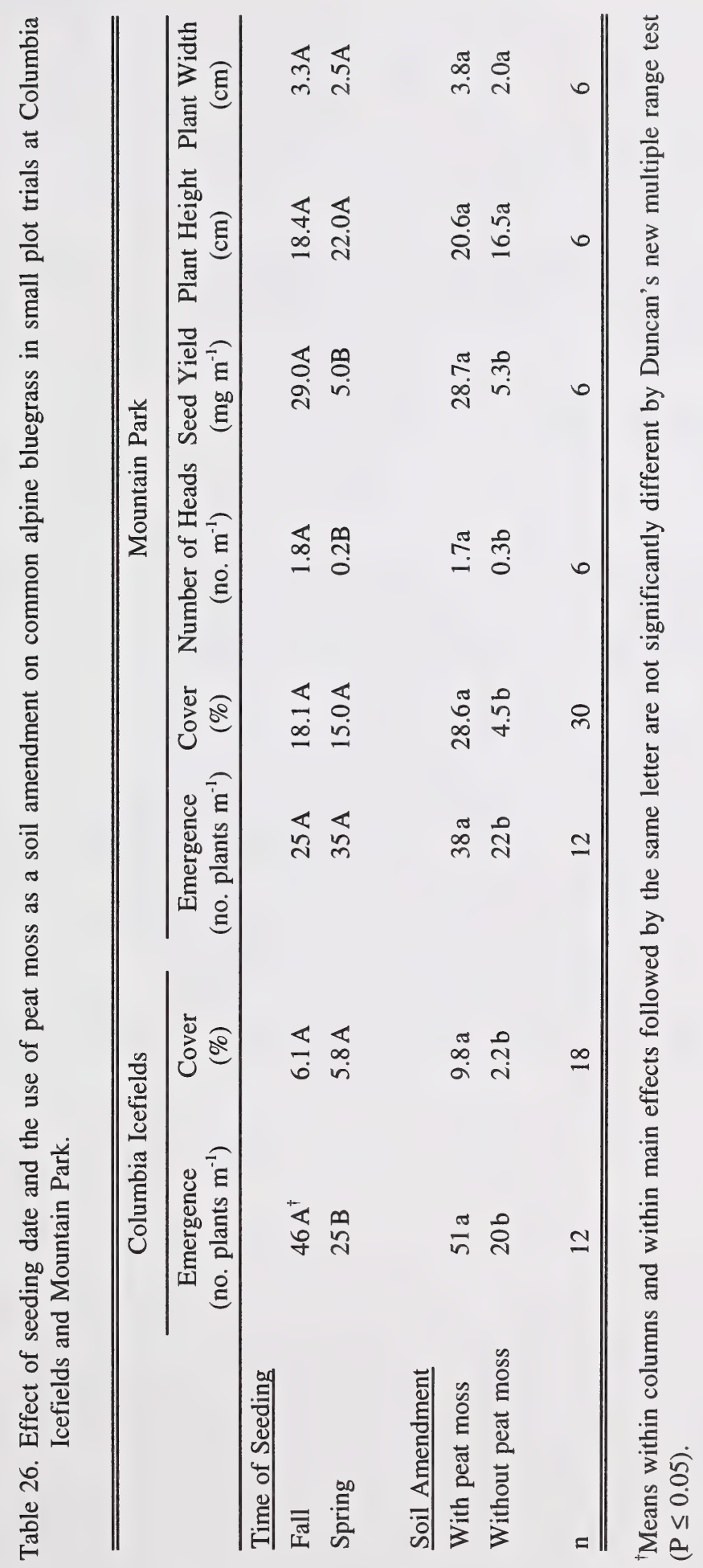


Table 27. Effect of seeding date on the emergence and percent cover of common alpine bluegrass in a small plot trial at Columbia Icefields.

\begin{tabular}{lcc}
\hline \hline Time of Seeding & $\begin{array}{c}\text { Emergence } \\
\left(\text { no. plants } \mathrm{m}^{-1}\right)\end{array}$ & $\begin{array}{c}\text { Cover } \\
(\%)\end{array}$ \\
\hline Fall & $5.2 \mathrm{a}^{\dagger}$ & $1.8 \mathrm{a}$ \\
Spring & $2.2 \mathrm{a}$ & $2.5 \mathrm{a}$ \\
$\mathrm{n}$ & 3 & 6 \\
\hline \hline
\end{tabular}

${ }^{\dagger}$ Means within columns followed by the same letter are not significantly different by Duncan's new multiple range test $(\mathrm{P} \leq 0.05)$. 
The release of AEC Blueridge alpine bluegrass and AEC Glacier alpine bluegrass will provide easily accessible sources of native grass seed adapted for reclaiming disturbed sites in the mountains and foothills. These varieties are well adapted to the short growing seasons characteristic of higher elevations. AEC Blueridge is adapted to the highest elevations while AEC Glacier is adapted to slightly lower elevations. AEC Glacier appears to be more drought tolerant than AEC Blueridge and it produced more seed at plains sites during dry growing seasons. Although these varieties were released as pure lines, we recommend that they be incorporated into seed mixtures containing other native plant species and varieties to maximize genetic and species diversity and improve the likelihood of obtaining a good plant cover in any one location. Mixtures of several species have a better chance of some species being adapted to the conditions found in individual microsites within a large reclamation project.

When growing these alpine bluegrass varieties for seed production, seed into a clean seedbed using rates of 2 to $4 \mathrm{~kg} \mathrm{ha}^{-1}$. Seeding in May will give the best results. Place seed a maximum of $1 \mathrm{~cm}$ deep and use row spacings of 20 to $40 \mathrm{~cm}$. The application of fertilizer is generally not necessary. Weed control is difficult because there are no recommended selective herbicides for alpine bluegrass. Pre-plant and spot spraying with glyphosate may be necessary to control quackgrass, Canada thistle, and other weeds. Alpine bluegrass should be harvested by direct combining to minimize shattering losses. At Vegreville, AEC Glacier alpine bluegrass is harvested in late June while AEC Blueridge is generally harvested in the second week of July.

At high elevations, reclamation plantings of alpine bluegrass should be seeded in late fall to take maximum advantage of spring snowmelt. The use of additional topsoil, mulches, or organic matter such as peat moss or manure is beneficial to successful establishment of alpine bluegrass on reclamation sites. Fertilizer applications are not necessary although they may improve plant growth and cover.

In addition to these alpine bluegrass varieties, the Alberta Environmental Centre has also developed and released three slender wheatgrass varieties: AEC Highlander slender wheatgrass (released in 1993), AEC Hillcrest awned slender wheatgrass (released in 1994), and AEC Mountaineer broadglumed wheatgrass (released in 1995). Slender wheatgrass is adapted to lower elevations than alpine bluegrass although broadglumed wheatgrass grows well and 
produces seed up to elevations of $2300 \mathrm{~m}$. Slender wheatgrass establishes rapidly to provide a quick cover on reclamation sites so it is a useful addition to reclamation seed mixes.

Cooperative research with Wild Rose Consulting Inc. has also led to the development and release of common seed of a native legume species, Astragalus alpinus (Smreciu 1993). This native legume is adapted to the mountains and foothills and its release provides an important source of native legume seed for inclusion in reclamation seed mixes. 
Allard, R.W. 1960. Principles of plant breeding. John Wiley and Sons, Inc. New York. 485pp.

Ali, S., ed. 1991. Guide to crop protection in Alberta. Part 1 - Chemical. Alberta Agriculture Agdex 606-1. 216pp.

Ali, S., ed. 1993. Crop protection with chemicals. Alberta Agriculture Agdex 606-1. 262pp.

Ali, S., ed. 1995. Crop protection with chemicals. Alberta Agriculture, Food and Rural Development. Agdex 606-1. 347pp.

Bolton, J.L. ca. 1985. Pedigreed forage seed production. Canadian Seed Growers Association. $24 \mathrm{pp}$.

Bradley, C. 1994. Using native plants in reclamation and revegetation in Alberta: Results of a workshop hosted by Alberta Native Plant Council and Ducks Unlimited Canada. February 25, 1994. Edmonton, AB. 38pp.

Brown, R.W., and J.C. Chambers. 1989. Reclamation of severely disturbed alpine ecosystems: New perspectives. In: Walker, D.G., C.B. Powter, and M.W. Pole, eds. Proceedings of the Conference: Reclamation, a Global Perspective. Alberta Land Conservation and Reclamation Council Report \#RRTAC 89-2. Vol. 1: pp. 59-68.

Brown, R.W., R.S. Johnston, and J.C. Chambers. 1984. Responses of seeded native grasses to repeated fertilizer applications on acidic alpine mine spoils. In: Colbert, T.A., and R.L. Cuany, eds. Proceedings: High-Altitude Revegetation Workshop No. 6. Colorado State University, Fort Collins, Colorado. pp. 200-214.

Brown, R.W., R.S. Johnston, B.Z. Richardson, and E.E. Farmer. 1976. Rehabilitation of alpine disturbances: Beartooth Plateau, Montana. In: Zuck, R.H., and L.F. Brown, eds. HighAltitude Revegetation Workshop No. 2 Colorado State University, Fort Collins, Colorado. pp. 58-73.

Brown, R.W., R.S. Johnston, and D.A. Johnson. 1978. Rehabilitation of alpine tundra disturbances. Journal of Soil and Water Conservation 33(4): 154-160.

Chapin, F.S., III. 1980. The mineral nutrition of wild plants. Annual Review of Ecology and Systematics. 11: 233-260.

Hardy BBT Limited. 1989. Manual of plant species suitability for reclamation in Alberta - 2nd Edition. Alberta Land Conservation and Reclamation Council Report No. RRTAC 89-4. 436pp.

Hardy BBT Limited. 1990. Reclamation of disturbed alpine lands: A literature review. Alberta Land Conservation and Reclamation Council Report No. RRTAC 90-7. 209pp. 
Hermesh, R. and S.N. Acharya. 1992. Influence of maternal plant environment and provenance on alpine bluegrass seed germination. Can. J. Plant Sci. 72: 801-808.

Hodgson, H.J., R.L. Taylor, A.C. Wilton, and L.J. Klebesadel. 1971. Registration of Nugget Kentucky bluegrass (Reg. No. 5). Crop Science 11: 938.

Jacklin, A.W. 1976. Canada bluegrass plant. United States Patent. Plant Pat. 3,828.

Joyce, J. 1993. Native plants: Exploring grass seed production and markets. Report prepared for Agriculture Canada Prairie Farm Rehabilitation Administration and Ducks Unlimited Canada. 53pp.

Mahler, D. 1990. Large scale use of wild harvested local seed. In: Keammerer, W.R., and J. Todd, eds. Proceedings: High Altitude Revegetation Workshop No. 9. Colorado State University, Fort Collins, Colorado. pp. 7-10.

Martens, J.W., W.L. Seaman, and T.G. Atkinson, eds. 1984. Diseases of field crops in Canada. An illustrated compendium. The Canadian Phytopathological Society. 160 pp.

Moss, E.H. 1983. Flora of Alberta. A manual of flowering plants, conifers, ferns, and fern allies found growing without cultivation in the Province of Alberta, Canada. Second edition revised by J. G. Packer. University of Toronto Press, Toronto. 687pp.

Müntzing, A. 1954. The cytological basis of polymorphism in Poa alpina. Hereditas 40: 459516.

Müntzing, A., and G. Müntzing. 1971. An apomictic biotype of Poa alpina in the Koster islands of Sweden. Hereditas 67: 143-144.

Najda, H., K. Lopetinsky, M. Bjorge, and B. Witbeck. 1994. Harvesting grass seed. Alberta Agriculture, Food and Rural Development. Agdex 127/50-1. 5pp.

Reeder, J.D., and W.J. McGinnies. 1989. Response of established forages on reclaimed mined land to fertilizer N and P. Journal of Range Management 42(4): 327-332.

SAS Institute Inc. 1990. SAS/STAT User's Guide, Version 6, Fourth Edition. Volume 2. 1739 pp.

Schuman, G.E., E.M. Taylor, Jr., and F. Rauzi. 1991. Forage production of reclaimed mined lands as influenced by nitrogen fertilization and mulching practice. Journal of Range Management 44(4): 382-384.

Smreciu, A. 1993. Native legumes for reclamation in Alberta. Alberta Conservation and Reclamation Council Report No. RRTAC 93-9. 94pp. 
Takyi, S.K. 1984. Plant cover establishment methods on a severe Rocky Mountain Foothills site. In: Revegetation methods for Alberta's mountains and foothills, proceedings of a workshop held 30 April - 1 May 1984, Edmonton, AB. Alberta Land Conservation and Reclamation Council Report \#RRTAC 85-1: pp. 112-144.

Thornburg, A.A. 1982. Plant materials for use on surface-mined lands in arid and semiarid regions. Soil Conservation Service, United States Department of Agriculture. 88pp.

Ziemkiewicz, P.F. 1984. Effects of topsoiling, maintenance fertilizer and species selection on long-term revegetation success. In: Revegetation methods for Alberta's mountains and foothills, proceedings of a workshop held 30 April - 1 May 1984, Edmonton, AB. Alberta Land Conservation and Reclamation Council Report \#RRTAC 85-1: pp. 50-77.

\section{1 $\quad$ Related Publications}

Acharya, S.N. 1989. Germination response of two alpine grasses from the Rocky Mountains of Alberta. Can. J. Plant Sci. 69: 1165-1177.

Acharya, S. N., B. A. Darroch, R. Hermesh, and J. Woosaree. 1992. Salt stress tolerance in native Alberta populations of slender wheatgrass and bluegrass. Can. J. Plant Sci. 72: 785792.

Acharya, S. N., and R. Hermesh, 1988. Native species for reclamation - east slopes. RRTAC progress report. $11 \mathrm{pp}$.

Acharya, S. N., and R. Hermesh, 1987. Native species for reclamation - east slopes. RRTAC progress report. $39 \mathrm{pp}$.

Acharya, S. N., and R. Hermesh, 1986. Native species for reclamation, research and development -east slopes. RRTAC progress report. $25 \mathrm{pp}$.

Acharya, S. N., and R. Hermesh, 1985. Native species for reclamation - east slopes. RRTAC progress report. $24 \mathrm{pp}$.

Darroch, B.A. 1996. Development of Three Slender Wheatgrass Reclamation Varieties. Alberta Environmental Centre, Vegreville, AB. AECV96-R2. 123 pp.

Darroch, B. A. 1994. CO1 - Native grasses for land reclamation in the east slopes. Interim Progress Report, 1993/94. Prepared for the Reclamation Research Technical Advisory Committee and Parks Canada. 36pp. 
Darroch, B. A., 1993. Native grasses for land reclamation in the east slopes. Interim progress report, 1992/93. Prepared for the Reclamation Research Technical Advisory Committee, the Canadian Parks Service and the Alberta Agricultural Research Institute. $42 \mathrm{pp}$.

Darroch, B. A., 1992. Native grasses for land reclamation in the east slopes. Interim progress report, 1991/92. Prepared for the Reclamation Research Technical Advisory Committee, the Canadian Parks Service and the Alberta Agricultural Research Institute. $27 \mathrm{pp}$.

Darroch, B. A., and S. N. Acharya. 1995. AEC Highlander slender wheatgrass. Can. J. Plant Sci. 75: 699-701.

Darroch, B. A., and S. N. Acharya. 1995. AEC Hillcrest awned slender wheatgrass. Can. J. Plant Sci. (in press).

Darroch, B. A., and S. N. Acharya. 1995. AEC Blueridge alpine bluegrass. Can. J. Plant Sci. (in press).

Darroch, B. A., and M.D. Pahl. 1991. Native grasses for land reclamation in the east slopes. Interim progress report, 1989/91. Prepared for the Reclamation Research Technical Advisory Committee, the Canadian Parks Service and the Alberta Agricultural Research Institute. $27 \mathrm{pp}$.

Hermesh, R. and S.N. Acharya. 1992. Influence of maternal plant environment and provenance on alpine bluegrass seed germination. Can. J. Plant Sci. 72: 801-808.

Hermesh, R. and S.N. Acharya. 1987. Reproductive response to three temperature regimes of four Poa alpina populations from the Rocky Mountains of Alberta, Canada. Arctic and Alpine Research 19: 321-326.

Hermesh, R.,J. Woosaree, B.A. Darroch, S.N. Acharya, and A. Smreciu. 1990. Initial selection for salt tolerance in Rocky Mountain accessions of slender wheatgrass and alpine bluegrass. Alberta Land Conservation and Reclamation Council Report No. RRTAC 90-2 40pp.

Smreciu, A. 1993. Native legumes for reclamation in Alberta. Alberta Conservation and Reclamation Council Report No. RRTAC 93-9. 94pp. 
APPENDIX A

PERFORMANCE OF ALPINE BLUEGRASS LINES IN INDIVIDUAL PROVENANCE TRIALS 
Table A.1. Performance of selected alpine bluegrass lines in transplanted provenance trial 1 at Columbia Icefields in 1989. The trial was established in 1988.

\begin{tabular}{rcccc}
\hline \hline Line & $\begin{array}{c}\text { Number of Heads } \\
\left(\text { no. plant }{ }^{-1}\right)\end{array}$ & $\begin{array}{c}\text { Plant Height } \\
(\mathrm{cm})\end{array}$ & $\begin{array}{c}\text { Plant Width } \\
(\mathrm{cm})\end{array}$ & $\begin{array}{c}\text { Flag Leaf Length } \\
(\mathrm{cm})\end{array}$ \\
\hline 745 & $11.3 \mathrm{~cd}^{\dagger}$ & $3.8 \mathrm{k}$ & $4.8 \mathrm{c}$ & $1.5 \mathrm{a}$ \\
752 & $19.2 \mathrm{~b}$ & $5.8 \mathrm{jk}$ & $6.6 \mathrm{bc}$ & $2.1 \mathrm{a}$ \\
864 & $3.4 \mathrm{e}$ & $11.4 \mathrm{defg}$ & $6.2 \mathrm{bc}$ & $1.3 \mathrm{a}$ \\
907 & $5.3 \mathrm{cde}$ & $11.6 \mathrm{def}$ & $6.4 \mathrm{bc}$ & $1.3 \mathrm{a}$ \\
1001 & $1.5 \mathrm{e}$ & $8.0 \mathrm{hij}$ & $6.4 \mathrm{bc}$ & $1.6 \mathrm{a}$ \\
1003 & $1.6 \mathrm{e}$ & $6.8 \mathrm{ij}$ & $5.8 \mathrm{bc}$ & $1.4 \mathrm{a}$ \\
1079 & $6.5 \mathrm{cde}$ & $12.8 \mathrm{cde}$ & $7.6 \mathrm{ab}$ & $1.6 \mathrm{a}$ \\
1207 & $4.2 \mathrm{de}$ & $8.8 \mathrm{ghi}$ & $5.8 \mathrm{bc}$ & $1.5 \mathrm{a}$ \\
1214 & $5.7 \mathrm{cde}$ & $7.2 \mathrm{ij}$ & $5.9 \mathrm{bc}$ & $1.5 \mathrm{a}$ \\
1229 & $6.1 \mathrm{cde}$ & $14.4 \mathrm{c}$ & $6.2 \mathrm{bc}$ & $1.6 \mathrm{a}$ \\
1245 & $4.1 \mathrm{de}$ & $13.8 \mathrm{~cd}$ & $5.6 \mathrm{bc}$ & $1.3 \mathrm{a}$ \\
1267 & $4.3 \mathrm{de}$ & $10.8 \mathrm{efg}$ & $7.6 \mathrm{ab}$ & $1.5 \mathrm{a}$ \\
$1448^{\ddagger}$ & - & - & - & - \\
1588 & $3.2 \mathrm{e}$ & $10.0 \mathrm{fgh}$ & $5.4 \mathrm{bc}$ & $1.6 \mathrm{a}$ \\
1760 & $3.8 \mathrm{de}$ & $9.2 \mathrm{fghi}$ & $7.2 \mathrm{~b}$ & $1.2 \mathrm{a}$ \\
Reubens & $12.7 \mathrm{bc}$ & $30.6 \mathrm{a}$ & $9.4 \mathrm{a}$ & $2.3 \mathrm{a}$ \\
Nugget & $35.8 \mathrm{a}$ & $20.4 \mathrm{~b}$ & $7.6 \mathrm{ab}$ & $1.8 \mathrm{a}$ \\
\hline \hline
\end{tabular}

'Means within columns followed by the same letter are not significantly different by Duncan's new multiple range test $(\mathrm{P} \leq 0.05)$. $\mathrm{n}=5$ for all means.

${ }^{\ddagger}$ At the time of planting there were no plants of line 1448 for this trial. 







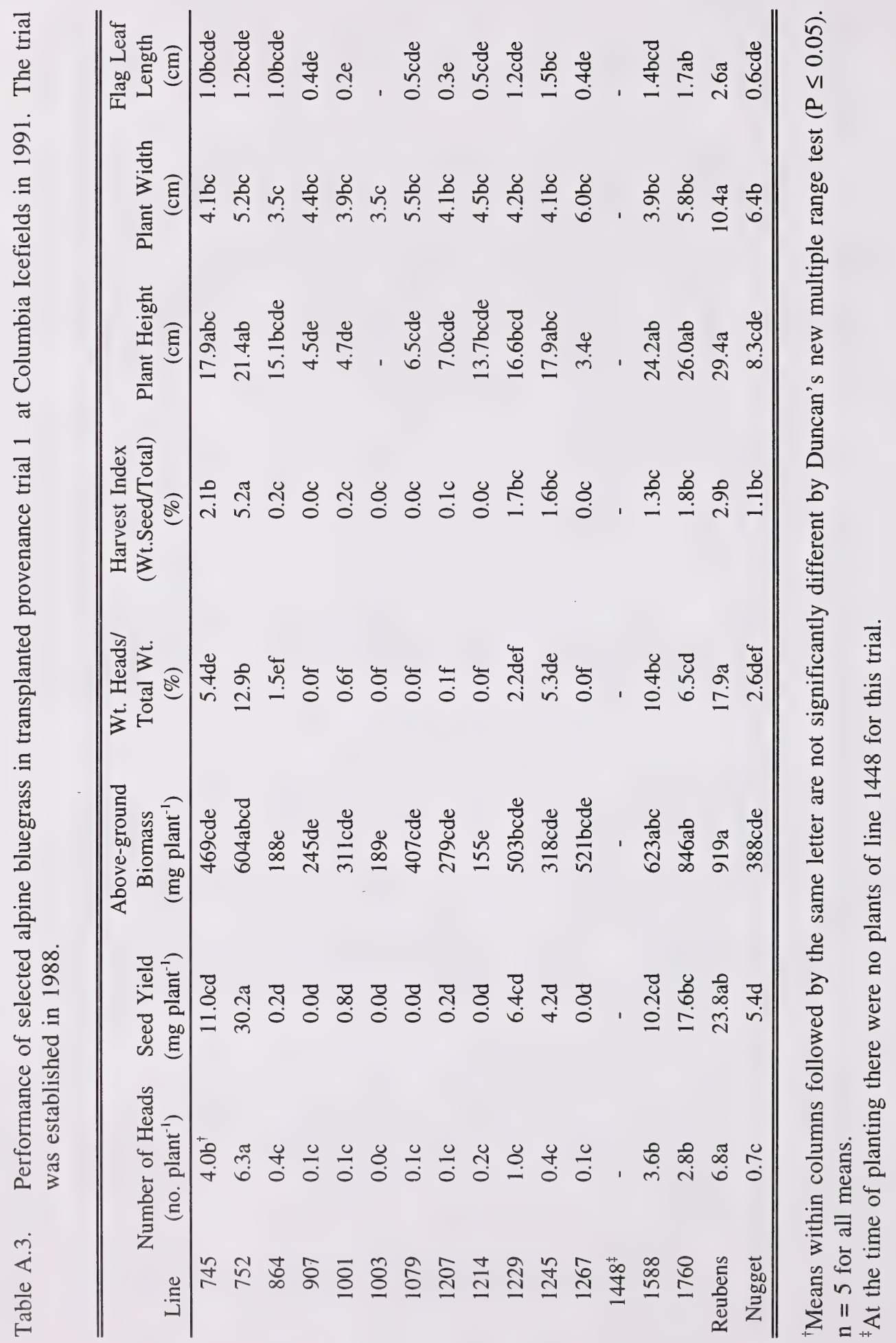


Table A.4. Performance of selected alpine bluegrass in transplanted provenance trial 1 at Columbia Icefields in 1992. The trial was established in 1988.

\begin{tabular}{rcccc}
\hline \hline Line & $\begin{array}{c}\text { Number of Heads } \\
\left(\text { no. plant }{ }^{-1}\right)\end{array}$ & $\begin{array}{c}\text { Seed Yield } \\
\left(\mathrm{mg} \mathrm{plant}^{-1}\right)\end{array}$ & $\begin{array}{c}\text { Plant Height } \\
(\mathrm{cm})\end{array}$ & $\begin{array}{c}\text { Plant Width } \\
(\mathrm{cm})\end{array}$ \\
\hline 745 & $5.5 \mathrm{bc}^{\dagger}$ & $66.8 \mathrm{bc}$ & $12.2 \mathrm{de}$ & $6.0 \mathrm{c}$ \\
752 & $9.9 \mathrm{a}$ & $110.5 \mathrm{ab}$ & $16.6 \mathrm{bcde}$ & $7.0 \mathrm{c}$ \\
864 & $0.9 \mathrm{e}$ & $5.9 \mathrm{c}$ & $21.0 \mathrm{abcd}$ & $5.8 \mathrm{c}$ \\
907 & $1.7 \mathrm{de}$ & $20.0 \mathrm{c}$ & $18.6 \mathrm{abcd}$ & $5.6 \mathrm{c}$ \\
1001 & $0.8 \mathrm{e}$ & $26.4 \mathrm{c}$ & $17.8 \mathrm{abcd}$ & $5.6 \mathrm{c}$ \\
1003 & $0.2 \mathrm{e}$ & $7.3 \mathrm{c}$ & $9.8 \mathrm{de}$ & $4.8 \mathrm{c}$ \\
1079 & $0.6 \mathrm{e}$ & $42.7 \mathrm{bc}$ & $16.8 \mathrm{bcde}$ & $6.4 \mathrm{c}$ \\
1207 & $0.5 \mathrm{e}$ & $7.0 \mathrm{c}$ & $12.2 \mathrm{de}$ & $5.4 \mathrm{c}$ \\
1214 & $0.8 \mathrm{e}$ & $24.9 \mathrm{c}$ & $13.0 \mathrm{cde}$ & $6.0 \mathrm{c}$ \\
1229 & $2.3 \mathrm{de}$ & $57.9 \mathrm{bc}$ & $24.4 \mathrm{ab}$ & $6.0 \mathrm{c}$ \\
1245 & $2.0 \mathrm{de}$ & $25.6 \mathrm{c}$ & $25.6 \mathrm{ab}$ & $5.2 \mathrm{c}$ \\
1267 & $1.1 \mathrm{e}$ & $19.4 \mathrm{c}$ & $20.0 \mathrm{abcd}$ & $6.4 \mathrm{c}$ \\
$1448^{\ddagger}$ & - & - & - & - \\
1588 & $2.6 \mathrm{de}$ & $144.1 \mathrm{a}$ & $19.8 \mathrm{abcd}$ & $6.8 \mathrm{c}$ \\
1760 & $3.6 \mathrm{~cd}$ & $45.3 \mathrm{bc}$ & $23.6 \mathrm{abc}$ & $7.2 \mathrm{c}$ \\
Reubens & $6.2 \mathrm{~b}$ & $20.3 \mathrm{c}$ & $28.6 \mathrm{a}$ & $12.0 \mathrm{~b}$ \\
Nugget & $1.2 \mathrm{e}$ & $11.7 \mathrm{c}$ & $6.0 \mathrm{e}$ & $19.4 \mathrm{a}$ \\
\hline \hline
\end{tabular}

${ }^{\dagger}$ Means within columns followed by the same letter are not significantly different by Duncan's new multiple range test $(\mathrm{P} \leq 0.05)$. $\mathrm{n}=5$ for all means.

${ }^{\ddagger}$ At the time of planting there were no plants of line 1448 for this trial. 
Table A.5. Performance of selected alpine bluegrass in transplanted provenance trial 1 at Columbia Icefields in 1993. The trial was established in 1988.

\begin{tabular}{rcccc}
\hline \hline Line & $\begin{array}{c}\text { Number of Heads } \\
\left(\text { no. plant }{ }^{-1}\right)\end{array}$ & $\begin{array}{c}\text { Seed Yield } \\
\left(\text { mg plant }^{-1}\right)\end{array}$ & $\begin{array}{c}\text { Plant Height } \\
(\mathrm{cm})\end{array}$ & $\begin{array}{c}\text { Plant Width } \\
(\mathrm{cm})\end{array}$ \\
\hline 745 & $6.0 \mathrm{a}^{\dagger}$ & $27.4 \mathrm{abcd}$ & $16.9 \mathrm{bc}$ & $4.8 \mathrm{~cd}$ \\
752 & $6.1 \mathrm{a}$ & $41.9 \mathrm{ab}$ & $19.6 \mathrm{ab}$ & $7.9 \mathrm{bc}$ \\
864 & $0.6 \mathrm{~d}$ & $5.9 \mathrm{def}$ & $21.6 \mathrm{ab}$ & $5.8 \mathrm{bcd}$ \\
907 & $1.9 \mathrm{bcd}$ & $25.8 \mathrm{abcde}$ & $22.3 \mathrm{ab}$ & $4.8 \mathrm{~cd}$ \\
1001 & $0.9 \mathrm{~d}$ & $18.9 \mathrm{bcdef}$ & $25.6 \mathrm{a}$ & $5.0 \mathrm{~cd}$ \\
1003 & $0.4 \mathrm{~d}$ & $6.5 \mathrm{def}$ & $25.0 \mathrm{a}$ & $4.4 \mathrm{~d}$ \\
1079 & $0.7 \mathrm{~d}$ & $8.7 \mathrm{def}$ & $19.6 \mathrm{ab}$ & $6.0 \mathrm{bcd}$ \\
1207 & $0.2 \mathrm{~d}$ & $1.7 \mathrm{ef}$ & $22.0 \mathrm{ab}$ & $4.4 \mathrm{~d}$ \\
1214 & $0.7 \mathrm{~d}$ & $7.1 \mathrm{def}$ & $23.1 \mathrm{ab}$ & $5.6 \mathrm{bcd}$ \\
1229 & $1.3 \mathrm{~cd}$ & $15.4 \mathrm{cdef}$ & $24.0 \mathrm{a}$ & $5.4 \mathrm{bcd}$ \\
1245 & $0.9 \mathrm{~d}$ & $11.5 \mathrm{def}$ & $23.5 \mathrm{ab}$ & $5.2 \mathrm{bcd}$ \\
1267 & $1.7 \mathrm{bcd}$ & $37.4 \mathrm{abc}$ & $23.3 \mathrm{ab}$ & $6.0 \mathrm{bcd}$ \\
$1448^{\ddagger}$ & - & - & - & - \\
1588 & $1.8 \mathrm{bcd}$ & $15.4 \mathrm{cdef}$ & $25.9 \mathrm{a}$ & $5.4 \mathrm{bcd}$ \\
1760 & $3.3 \mathrm{~b}$ & $43.5 \mathrm{a}$ & $26.7 \mathrm{a}$ & $8.2 \mathrm{~b}$ \\
Reubens & $2.6 \mathrm{bc}$ & $0.0 \mathrm{f}$ & $23.2 \mathrm{ab}$ & $13.0 \mathrm{a}$ \\
Nugget & $0.9 \mathrm{~d}$ & $3.1 \mathrm{def}$ & $12.5 \mathrm{c}$ & $11.2 \mathrm{a}$ \\
\hline \hline
\end{tabular}

${ }^{\dagger}$ Means within columns followed by the same letter are not significantly different by Duncan's new multiple range test $(\mathrm{P} \leq 0.05)$. $\mathrm{n}=5$ for all means.

${ }^{\ddagger}$ At the time of planting there were no plants of line 1448 for this trial. 
Table A.6. Performance of selected alpine bluegrass in transplanted provenance trial 1 at Columbia Icefields in 1994. The trial was established in 1988.

\begin{tabular}{|c|c|c|c|c|}
\hline Line & $\begin{array}{c}\text { Number of Heads } \\
\left(\text { no. plant }{ }^{-1}\right)\end{array}$ & $\begin{array}{l}\text { Seed Yield } \\
\left(\mathrm{mg} \mathrm{plant}^{-1}\right)\end{array}$ & $\begin{array}{l}\text { Plant Height } \\
(\mathrm{cm})\end{array}$ & $\begin{array}{c}\text { Plant Width } \\
(\mathrm{cm})\end{array}$ \\
\hline 745 & $5.5 b^{\dagger}$ & $58.4 b c$ & $15.0 \mathrm{cde}$ & $9.6 \mathrm{cde}$ \\
\hline 752 & $9.4 \mathrm{a}$ & $83.0 \mathrm{~b}$ & $13.6 \mathrm{de}$ & $12.4 \mathrm{bcd}$ \\
\hline 864 & 1.7defgh & $26.0 c$ & $16.8 \mathrm{bcde}$ & $7.4 \mathrm{e}$ \\
\hline 907 & 1.4defgh & $34.8 \mathrm{c}$ & $16.8 \mathrm{bcde}$ & $8.4 \mathrm{de}$ \\
\hline 1001 & $0.8 \mathrm{fgh}$ & $21.2 \mathrm{c}$ & $17.8 \mathrm{abcd}$ & $7.4 \mathrm{e}$ \\
\hline 1003 & $0.7 \mathrm{gh}$ & $8.8 \mathrm{c}$ & 18.5abcd & $7.8 \mathrm{e}$ \\
\hline 1079 & $0.9 \mathrm{fgh}$ & $28.4 \mathrm{c}$ & $16.4 \mathrm{bcde}$ & $9.0 \mathrm{cde}$ \\
\hline 1207 & $0.8 \mathrm{fgh}$ & $12.8 c$ & $17.0 \mathrm{bcde}$ & $7.8 \mathrm{e}$ \\
\hline 1214 & 1.0efgh & $19.8 c$ & $14.0 \mathrm{de}$ & $7.6 \mathrm{e}$ \\
\hline 1229 & $2.5 \mathrm{defg}$ & $49.4 b c$ & $22.0 \mathrm{ab}$ & $10.8 \mathrm{bcde}$ \\
\hline 1245 & 1.3defgh & $28.2 \mathrm{c}$ & $21.2 \mathrm{abc}$ & $9.0 \mathrm{cde}$ \\
\hline 1267 & 1.7defgh & $49.2 b c$ & 19.4abcd & $10.6 \mathrm{cde}$ \\
\hline $1448^{\ddagger}$ & - & - & - & - \\
\hline 1588 & $3.5 \mathrm{bcd}$ & $83.6 b$ & $22.8 \mathrm{ab}$ & $11.4 \mathrm{bcde}$ \\
\hline 1760 & $5.2 b c$ & $147.6 a$ & $23.6 \mathrm{a}$ & $12.8 \mathrm{abc}$ \\
\hline Reubens & $3.1 \mathrm{cdef}$ & $21.6 c$ & $20.6 \mathrm{abc}$ & $14.6 \mathrm{ab}$ \\
\hline Nugget & $3.3 \mathrm{bcde}$ & $32.6 c$ & $10.6 \mathrm{e}$ & $16.4 \mathrm{a}$ \\
\hline
\end{tabular}

${ }^{\dagger}$ Means within columns followed by the same letter are not significantly different by Duncan's new multiple range test $(\mathrm{P} \leq 0.05)$. $\mathrm{n}=5$ for all means.

${ }^{\ddagger}$ At the time of planting there were no plants of line 1448 for this trial. 
Table A.7. Performance of selected alpine bluegrass in transplanted provenance trial 2 at Columbia Icefields in 1990. The trial was established in 1989.

\begin{tabular}{rccccc}
\hline \hline \multicolumn{1}{c}{ Line } & $\begin{array}{c}\text { Number of Heads } \\
\left(\text { no. plant }{ }^{-1}\right)\end{array}$ & $\begin{array}{c}\text { Seed Yield } \\
\left(\mathrm{mg} \mathrm{plant}^{-1}\right)\end{array}$ & $\begin{array}{c}\text { Plant Height } \\
(\mathrm{cm})\end{array}$ & $\begin{array}{c}\text { Plant Width } \\
(\mathrm{cm})\end{array}$ & $\begin{array}{c}\text { Flag Leaf Length } \\
(\mathrm{cm})\end{array}$ \\
\hline 745 & $1.2 \mathrm{bcd}^{\dagger}$ & $10.8 \mathrm{a}$ & $15.0 \mathrm{de}$ & $3.1 \mathrm{bc}$ & $0.6 \mathrm{~b}$ \\
752 & $1.9 \mathrm{abcd}$ & $10.1 \mathrm{a}$ & $12.7 \mathrm{e}$ & $2.5 \mathrm{c}$ & $1.0 \mathrm{~b}$ \\
864 & $2.7 \mathrm{abc}$ & $4.3 \mathrm{a}$ & $16.0 \mathrm{cde}$ & $3.0 \mathrm{bc}$ & $0.5 \mathrm{~b}$ \\
907 & $0.6 \mathrm{~cd}$ & $5.1 \mathrm{a}$ & $19.0 \mathrm{abcde}$ & $3.0 \mathrm{bc}$ & $1.2 \mathrm{~b}$ \\
1001 & $0.5 \mathrm{~cd}$ & $4.8 \mathrm{a}$ & $19.3 \mathrm{abcd}$ & $4.0 \mathrm{bc}$ & $0.7 \mathrm{~b}$ \\
1003 & $1.4 \mathrm{bcd}$ & $20.1 \mathrm{a}$ & $23.5 \mathrm{ab}$ & $4.5 \mathrm{~b}$ & $1.3 \mathrm{~b}$ \\
1079 & $0.7 \mathrm{~cd}$ & $9.0 \mathrm{a}$ & $21.0 \mathrm{abcd}$ & $4.0 \mathrm{bc}$ & $0.8 \mathrm{~b}$ \\
1207 & $1.7 \mathrm{abcd}$ & $8.7 \mathrm{a}$ & $20.1 \mathrm{abcd}$ & $4.3 \mathrm{~b}$ & $0.8 \mathrm{~b}$ \\
1214 & $2.9 \mathrm{ab}$ & $20.7 \mathrm{a}$ & $17.3 \mathrm{bcde}$ & $3.5 \mathrm{bc}$ & $0.9 \mathrm{~b}$ \\
1229 & $0.0 \mathrm{~d}$ & $0.0 \mathrm{a}$ & - & $3.0 \mathrm{bc}$ & - \\
1245 & $0.7 \mathrm{~cd}$ & $5.3 \mathrm{a}$ & $20.8 \mathrm{abcd}$ & $4.0 \mathrm{bc}$ & $0.9 \mathrm{~b}$ \\
1267 & $1.0 \mathrm{bcd}$ & $12.2 \mathrm{a}$ & $22.5 \mathrm{abc}$ & $3.5 \mathrm{bc}$ & $1.0 \mathrm{~b}$ \\
1448 & $0.7 \mathrm{~cd}$ & $4.6 \mathrm{a}$ & $20.0 \mathrm{abcd}$ & $3.5 \mathrm{bc}$ & $1.0 \mathrm{~b}$ \\
1588 & $1.4 \mathrm{bcd}$ & $10.4 \mathrm{a}$ & $20.0 \mathrm{abcd}$ & $3.5 \mathrm{bc}$ & $0.8 \mathrm{~b}$ \\
$1760^{\ddagger}$ & - & - & - & - & - \\
Reubens & $3.5 \mathrm{a}$ & $21.4 \mathrm{a}$ & $25.5 \mathrm{a}$ & $8.0 \mathrm{a}$ & $2.6 \mathrm{a}$ \\
Nugget & $2.0 \mathrm{abcd}$ & $0.0 \mathrm{a}$ & $6.0 \mathrm{f}$ & $3.5 \mathrm{bc}$ & $1.0 \mathrm{~b}$ \\
\hline \hline
\end{tabular}

${ }^{\dagger}$ Means within columns followed by the same letter are not significantly different by Duncan's new multiple range test $(\mathrm{P} \leq 0.05)$. $\mathrm{n}=4$ for all means.

${ }^{\ddagger}$ At the time of planting there were no plants of line 1760 for this trial. 
Table A.8. Performance of selected alpine bluegrass in transplanted provenance trial 2 at Columbia Icefields in 1991. The trial was established in 1989.

\begin{tabular}{rccccc}
\hline \hline Line & $\begin{array}{c}\text { Number of Heads } \\
\left(\text { no. plant }{ }^{-1}\right)\end{array}$ & $\begin{array}{c}\text { Seed Yield } \\
\left(\mathrm{mg} \mathrm{plant}^{-1}\right)\end{array}$ & $\begin{array}{c}\text { Plant Height } \\
(\mathrm{cm})\end{array}$ & $\begin{array}{c}\text { Plant Width } \\
(\mathrm{cm})\end{array}$ & $\begin{array}{c}\text { Flag Leaf Length } \\
(\mathrm{cm})\end{array}$ \\
\hline 745 & $2.5 \mathrm{a}^{\dagger}$ & $7.0 \mathrm{a}$ & $12.6 \mathrm{a}$ & $2.0 \mathrm{~b}$ & $0.9 \mathrm{bc}$ \\
752 & $1.5 \mathrm{a}$ & $14.5 \mathrm{a}$ & $12.8 \mathrm{a}$ & $2.0 \mathrm{~b}$ & $0.7 \mathrm{c}$ \\
864 & $0.3 \mathrm{a}$ & $1.0 \mathrm{a}$ & $10.8 \mathrm{a}$ & $2.0 \mathrm{~b}$ & $0.5 \mathrm{c}$ \\
907 & $1.0 \mathrm{a}$ & $11.5 \mathrm{a}$ & $17.2 \mathrm{a}$ & $2.0 \mathrm{~b}$ & $1.7 \mathrm{ab}$ \\
1001 & $0.1 \mathrm{a}$ & $0.8 \mathrm{a}$ & $20.5 \mathrm{a}$ & $2.4 \mathrm{~b}$ & $1.0 \mathrm{bc}$ \\
1003 & $0.1 \mathrm{a}$ & $0.3 \mathrm{a}$ & $14.5 \mathrm{a}$ & $2.1 \mathrm{~b}$ & $0.5 \mathrm{c}$ \\
1079 & $0.3 \mathrm{a}$ & $2.3 \mathrm{a}$ & $18.0 \mathrm{a}$ & $2.3 \mathrm{~b}$ & $1.3 \mathrm{bc}$ \\
1207 & $0.6 \mathrm{a}$ & $0.5 \mathrm{a}$ & $12.6 \mathrm{a}$ & $2.4 \mathrm{~b}$ & $0.8 \mathrm{bc}$ \\
1214 & $0.5 \mathrm{a}$ & $0.5 \mathrm{a}$ & $15.8 \mathrm{a}$ & $2.8 \mathrm{~b}$ & $0.5 \mathrm{c}$ \\
1229 & $0.0 \mathrm{a}$ & $0.0 \mathrm{a}$ & - & $2.5 \mathrm{~b}$ & - \\
1245 & $0.0 \mathrm{a}$ & $0.0 \mathrm{a}$ & - & $2.1 \mathrm{~b}$ & - \\
1267 & $0.0 \mathrm{a}$ & $0.0 \mathrm{a}$ & - & $2.3 \mathrm{~b}$ & - \\
1448 & $0.6 \mathrm{a}$ & $1.5 \mathrm{a}$ & $23.0 \mathrm{a}$ & $2.5 \mathrm{~b}$ & $1.0 \mathrm{bc}$ \\
1588 & $1.1 \mathrm{a}$ & $1.0 \mathrm{a}$ & $19.5 \mathrm{a}$ & $2.8 \mathrm{~b}$ & $0.8 \mathrm{bc}$ \\
$1760^{\ddagger}$ & - & - & - & - & - \\
Reubens & $1.9 \mathrm{a}$ & $1.8 \mathrm{a}$ & $21.7 \mathrm{a}$ & $9.3 \mathrm{a}$ & $2.5 \mathrm{a}$ \\
Nugget & $0.0 \mathrm{a}$ & $0.0 \mathrm{a}$ & - & $3.0 \mathrm{~b}$ & - \\
\hline \hline
\end{tabular}

${ }^{\dagger}$ Means within columns followed by the same letter are not significantly different by Duncan's new multiple range test $(\mathrm{P} \leq 0.05)$. $\mathrm{n}=5$ for all means.

${ }^{\ddagger}$ At the time of planting there were no plants of line 1760 for this trial. 
Table A.9. Performance of selected alpine bluegrass in transplanted provenance trial 2 at Columbia Icefields in 1992. The trial was established in 1989.

\begin{tabular}{rcccc}
\hline \hline Line & $\begin{array}{c}\text { Number of Heads } \\
\left(\text { no. plant }{ }^{-1}\right)\end{array}$ & $\begin{array}{c}\text { Seed Yield } \\
\left(\text { mg plant }^{-1}\right)\end{array}$ & $\begin{array}{c}\text { Plant Height } \\
(\mathrm{cm})\end{array}$ & $\begin{array}{c}\text { Plant Width } \\
(\mathrm{cm})\end{array}$ \\
\hline 745 & $3.3 \mathrm{a}^{\dagger}$ & $12.9 \mathrm{a}$ & $10.5 \mathrm{a}$ & $2.8 \mathrm{~b}$ \\
752 & $1.9 \mathrm{ab}$ & $5.1 \mathrm{a}$ & $7.8 \mathrm{a}$ & $2.8 \mathrm{~b}$ \\
864 & $1.2 \mathrm{~b}$ & $3.7 \mathrm{a}$ & $3.8 \mathrm{a}$ & $3.0 \mathrm{~b}$ \\
907 & $0.2 \mathrm{~b}$ & $0.5 \mathrm{a}$ & $2.8 \mathrm{a}$ & $2.5 \mathrm{~b}$ \\
1001 & $0.1 \mathrm{~b}$ & $2.1 \mathrm{a}$ & $4.3 \mathrm{a}$ & $3.8 \mathrm{~b}$ \\
1003 & $0.0 \mathrm{~b}$ & $0.0 \mathrm{a}$ & - & $3.0 \mathrm{~b}$ \\
1079 & $0.0 \mathrm{~b}$ & $0.0 \mathrm{a}$ & - & $2.8 \mathrm{~b}$ \\
1207 & $0.0 \mathrm{~b}$ & $0.0 \mathrm{a}$ & - & $3.0 \mathrm{~b}$ \\
1214 & $0.0 \mathrm{~b}$ & $0.0 \mathrm{a}$ & - & $3.8 \mathrm{~b}$ \\
1229 & $0.0 \mathrm{~b}$ & $0.0 \mathrm{a}$ & - & $4.0 \mathrm{~b}$ \\
1245 & $0.0 \mathrm{~b}$ & $0.0 \mathrm{a}$ & - & $2.8 \mathrm{~b}$ \\
1267 & $0.0 \mathrm{~b}$ & $0.0 \mathrm{a}$ & - & $3.0 \mathrm{~b}$ \\
1448 & $0.8 \mathrm{~b}$ & $3.0 \mathrm{a}$ & $8.3 \mathrm{a}$ & $3.8 \mathrm{~b}$ \\
1588 & $0.6 \mathrm{~b}$ & $2.5 \mathrm{a}$ & $11.8 \mathrm{a}$ & $3.5 \mathrm{~b}$ \\
$1760^{\ddagger}$ & - & - & - & - \\
Reubens & $1.1 \mathrm{~b}$ & $0.6 \mathrm{a}$ & $9.8 \mathrm{a}$ & $9.3 \mathrm{a}$ \\
Nugget & $0.0 \mathrm{~b}$ & $0.0 \mathrm{a}$ & - & $4.0 \mathrm{~b}$ \\
\hline \hline
\end{tabular}

${ }^{\dagger}$ Means within columns followed by the same letter are not significantly different by Duncan's new multiple range test $(\mathrm{P} \leq 0.05)$. $\mathrm{n}=5$ for all means.

${ }^{\ddagger}$ At the time of planting there were no plants of line 1760 for this trial. 
Table A.10. Performance of selected alpine bluegrass in transplanted provenance trial 2 at Columbia Icefields in 1993. The trial was established in 1989.

\begin{tabular}{rcccc}
\hline \hline Line & $\begin{array}{c}\text { Number of Heads } \\
\left(\text { no. plant }{ }^{-1}\right)\end{array}$ & $\begin{array}{c}\text { Seed Yield } \\
\left(\mathrm{mg} \mathrm{plant}^{-1}\right)\end{array}$ & $\begin{array}{c}\text { Plant Height } \\
(\mathrm{cm})\end{array}$ & $\begin{array}{c}\text { Plant Width } \\
(\mathrm{cm})\end{array}$ \\
\hline 745 & $1.4 \mathrm{a}^{\dagger}$ & $6.5 \mathrm{a}$ & $12.9 \mathrm{a}$ & $3.0 \mathrm{~b}$ \\
752 & $0.3 \mathrm{~b}$ & $2.5 \mathrm{a}$ & $10.5 \mathrm{a}$ & $3.0 \mathrm{~b}$ \\
864 & $0.1 \mathrm{~b}$ & $0.0 \mathrm{a}$ & $3.0 \mathrm{a}$ & $3.3 \mathrm{~b}$ \\
907 & $0.1 \mathrm{~b}$ & $1.0 \mathrm{a}$ & $5.0 \mathrm{a}$ & $3.8 \mathrm{~b}$ \\
1001 & $0.2 \mathrm{~b}$ & $0.0 \mathrm{a}$ & - & $3.3 \mathrm{~b}$ \\
1003 & $1.4 \mathrm{a}$ & $0.0 \mathrm{a}$ & $5.3 \mathrm{a}$ & $3.5 \mathrm{~b}$ \\
1079 & $0.1 \mathrm{~b}$ & $0.0 \mathrm{a}$ & $5.0 \mathrm{a}$ & $2.8 \mathrm{~b}$ \\
1207 & $0.0 \mathrm{~b}$ & $0.0 \mathrm{a}$ & - & $3.0 \mathrm{~b}$ \\
1214 & $0.0 \mathrm{~b}$ & $0.0 \mathrm{a}$ & - & $3.3 \mathrm{~b}$ \\
1229 & $0.0 \mathrm{~b}$ & $0.0 \mathrm{a}$ & - & $3.0 \mathrm{~b}$ \\
1245 & $0.1 \mathrm{~b}$ & $0.3 \mathrm{a}$ & $6.3 \mathrm{a}$ & $3.0 \mathrm{~b}$ \\
1267 & $0.3 \mathrm{~b}$ & $10.5 \mathrm{a}$ & $6.5 \mathrm{a}$ & $3.5 \mathrm{~b}$ \\
1448 & $0.0 \mathrm{~b}$ & $0.0 \mathrm{a}$ & - & $4.0 \mathrm{~b}$ \\
1588 & $0.0 \mathrm{~b}$ & $0.0 \mathrm{a}$ & - & $3.8 \mathrm{~b}$ \\
$1760^{\ddagger}$ & - & - & - & - \\
Reubens & $0.2 \mathrm{~b}$ & $0.0 \mathrm{a}$ & $4.0 \mathrm{a}$ & $8.0 \mathrm{a}$ \\
Nugget & $0.0 \mathrm{~b}$ & $0.0 \mathrm{a}$ & - & $7.0 \mathrm{a}$ \\
\hline \hline
\end{tabular}

${ }^{\dagger}$ Means within columns followed by the same letter are not significantly different by Duncan's new multiple range test $(\mathrm{P} \leq 0.05)$. $\mathrm{n}=5$ for all means.

${ }^{\ddagger}$ At the time of planting there were no plants of line 1760 for this trial. 
Table A.11. Performance of selected alpine bluegrass in transplanted provenance trial 2 at Columbia Icefields in 1994. The trial was established in 1989.

\begin{tabular}{rcccc}
\hline \hline Line & $\begin{array}{c}\text { Number of Heads } \\
\left(\text { no. plant }{ }^{-1}\right)\end{array}$ & $\begin{array}{c}\text { Seed Yield } \\
\left(\mathrm{mg} \mathrm{plant}^{-1}\right)\end{array}$ & $\begin{array}{c}\text { Plant Height } \\
(\mathrm{cm})\end{array}$ & $\begin{array}{c}\text { Plant Width } \\
(\mathrm{cm})\end{array}$ \\
\hline 745 & $1.4 \mathrm{a}^{\dagger}$ & $5.8 \mathrm{a}$ & $6.3 \mathrm{a}$ & $6.3 \mathrm{a}$ \\
752 & $1.5 \mathrm{a}$ & $7.5 \mathrm{a}$ & $7.8 \mathrm{a}$ & $6.3 \mathrm{a}$ \\
864 & $0.1 \mathrm{c}$ & $0.0 \mathrm{a}$ & $7.0 \mathrm{a}$ & $4.8 \mathrm{a}$ \\
907 & $0.5 \mathrm{bc}$ & $2.3 \mathrm{a}$ & $7.7 \mathrm{a}$ & $4.8 \mathrm{a}$ \\
1001 & $0.0 \mathrm{c}$ & $0.0 \mathrm{a}$ & - & $4.3 \mathrm{a}$ \\
1003 & $0.1 \mathrm{c}$ & $0.3 \mathrm{a}$ & $7.0 \mathrm{a}$ & $4.3 \mathrm{a}$ \\
1079 & $0.0 \mathrm{c}$ & $0.0 \mathrm{a}$ & - & $4.3 \mathrm{a}$ \\
1207 & $0.0 \mathrm{c}$ & $0.0 \mathrm{a}$ & - & $4.3 \mathrm{a}$ \\
1214 & $0.0 \mathrm{c}$ & $0.0 \mathrm{a}$ & - & $4.7 \mathrm{a}$ \\
1229 & $0.0 \mathrm{c}$ & $0.0 \mathrm{a}$ & - & $5.0 \mathrm{a}$ \\
1245 & $0.2 \mathrm{c}$ & $1.3 \mathrm{a}$ & $14.0 \mathrm{a}$ & $5.0 \mathrm{a}$ \\
1267 & $0.0 \mathrm{c}$ & $0.0 \mathrm{a}$ & - & $5.3 \mathrm{a}$ \\
1448 & $0.3 \mathrm{bc}$ & $3.3 \mathrm{a}$ & $21.0 \mathrm{a}$ & $7.0 \mathrm{a}$ \\
1588 & $1.0 \mathrm{ab}$ & $13.8 \mathrm{a}$ & $18.0 \mathrm{a}$ & $7.0 \mathrm{a}$ \\
$1760^{\ddagger}$ & - & - & - & - \\
Reubens & $0.0 \mathrm{c}$ & $0.0 \mathrm{a}$ & - & $6.0 \mathrm{a}$ \\
Nugget & $0.0 \mathrm{c}$ & $0.0 \mathrm{a}$ & - & $5.0 \mathrm{a}$ \\
\hline \hline
\end{tabular}

${ }^{\dagger}$ Means within columns followed by the same letter are not significantly different by Duncan's new multiple range test $(\mathrm{P} \leq 0.05)$. $\mathrm{n}=5$ for all means.

${ }^{\ddagger}$ At the time of planting there were no plants of line 1760 for this trial. 
Table A.12. Performance of selected alpine bluegrass lines in seeded provenance trial at Columbia Icefields in 1989. The trial was seeded in 1987.

\begin{tabular}{rrrr}
\hline \hline Line & $\begin{array}{c}\text { Cover } \\
(\%)\end{array}$ & $\begin{array}{c}\text { Number of Heads } \\
\left(\text { no. } \mathrm{m}^{-1}\right)\end{array}$ & $\begin{array}{c}\text { Plant Height } \\
(\mathrm{cm})\end{array}$ \\
\hline 745 & $13.7 \mathrm{a}^{\dagger}$ & $5.8 \mathrm{a}$ & $12.1 \mathrm{ab}$ \\
752 & $10.7 \mathrm{a}$ & $5.2 \mathrm{a}$ & $4.8 \mathrm{ab}$ \\
864 & $15.3 \mathrm{a}$ & $3.2 \mathrm{a}$ & $11.9 \mathrm{ab}$ \\
907 & $21.7 \mathrm{a}$ & $21.3 \mathrm{a}$ & $7.9 \mathrm{ab}$ \\
1001 & $26.7 \mathrm{a}$ & $0.0 \mathrm{a}$ & - \\
1003 & $20.3 \mathrm{a}$ & $0.4 \mathrm{a}$ & $8.3 \mathrm{ab}$ \\
1079 & $4.0 \mathrm{a}$ & $0.0 \mathrm{a}$ & - \\
1207 & $5.7 \mathrm{a}$ & $2.8 \mathrm{a}$ & $6.2 \mathrm{ab}$ \\
1214 & $25.3 \mathrm{a}$ & $21.0 \mathrm{a}$ & $14.4 \mathrm{ab}$ \\
1229 & $25.0 \mathrm{a}$ & $26.0 \mathrm{a}$ & $8.2 \mathrm{ab}$ \\
1245 & $4.0 \mathrm{a}$ & $0.0 \mathrm{a}$ & - \\
1267 & $31.7 \mathrm{a}$ & $2.5 \mathrm{a}$ & $16.6 \mathrm{a}$ \\
1448 & $21.7 \mathrm{a}$ & $14.3 \mathrm{a}$ & $9.5 \mathrm{ab}$ \\
1588 & $28.7 \mathrm{a}$ & $1.5 \mathrm{a}$ & $9.1 \mathrm{ab}$ \\
1760 & $28.0 \mathrm{a}$ & $2.8 \mathrm{a}$ & $8.5 \mathrm{ab}$ \\
Reubens & $15.0 \mathrm{a}$ & $3.8 \mathrm{a}$ & $13.3 \mathrm{ab}$ \\
Nugget & $21.7 \mathrm{a}$ & $1.5 \mathrm{a}$ & $6.1 \mathrm{ab}$ \\
\hline \hline
\end{tabular}

${ }^{\dagger}$ Means within columns followed by the same letter are not significantly different by Duncan's new multiple range test $(\mathrm{P} \leq 0.05)$. $\mathrm{n}=3$ for all means. 
Table A.13. Performance of selected alpine bluegrass in seeded provenance trial at Columbia Icefields in 1990. The trial was established in 1987.

\begin{tabular}{rcccccc}
\hline \hline \multicolumn{1}{l}{ Line } & $\begin{array}{c}\text { Cover } \\
(\%)\end{array}$ & $\begin{array}{c}\text { Number of Heads } \\
\left(\text { no. } \mathrm{m}^{-1}\right)\end{array}$ & $\begin{array}{c}\text { Seed Yield } \\
\left(\mathrm{mg} \mathrm{m}^{-1}\right)\end{array}$ & $\begin{array}{c}\text { Plant Height } \\
(\mathrm{cm})\end{array}$ & $\begin{array}{c}\text { Plant Width } \\
(\mathrm{cm})\end{array}$ & $\begin{array}{c}\text { Flag Leaf } \\
\text { Length } \\
(\mathrm{cm})\end{array}$ \\
\hline 745 & $12.7 \mathrm{a}^{\dagger}$ & $17.0 \mathrm{a}$ & $109 \mathrm{~b}$ & $15.3 \mathrm{bcde}$ & $4.7 \mathrm{a}$ & $1.2 \mathrm{a}$ \\
752 & $18.7 \mathrm{a}$ & $21.0 \mathrm{a}$ & $218 \mathrm{~b}$ & $13.3 \mathrm{de}$ & $2.8 \mathrm{a}$ & $1.2 \mathrm{a}$ \\
864 & $21.0 \mathrm{a}$ & $13.2 \mathrm{a}$ & $108 \mathrm{~b}$ & $20.7 \mathrm{abcd}$ & $4.3 \mathrm{a}$ & $1.5 \mathrm{a}$ \\
907 & $17.7 \mathrm{a}$ & $14.8 \mathrm{a}$ & $104 \mathrm{~b}$ & $17.5 \mathrm{abcde}$ & $4.5 \mathrm{a}$ & $1.3 \mathrm{a}$ \\
1001 & $33.3 \mathrm{a}$ & $43.3 \mathrm{a}$ & $72 \mathrm{~b}$ & $24.5 \mathrm{a}$ & $6.5 \mathrm{a}$ & $1.5 \mathrm{a}$ \\
1003 & $27.7 \mathrm{a}$ & $8.0 \mathrm{a}$ & $141 \mathrm{~b}$ & $23.3 \mathrm{abc}$ & $4.7 \mathrm{a}$ & $1.2 \mathrm{a}$ \\
1079 & $7.7 \mathrm{a}$ & $6.0 \mathrm{a}$ & $89 \mathrm{~b}$ & $25.0 \mathrm{a}$ & $3.0 \mathrm{a}$ & $1.0 \mathrm{a}$ \\
1207 & $15.3 \mathrm{a}$ & $6.8 \mathrm{a}$ & $99 \mathrm{~b}$ & $23.5 \mathrm{abc}$ & $3.2 \mathrm{a}$ & $0.8 \mathrm{a}$ \\
1214 & $27.7 \mathrm{a}$ & $10.5 \mathrm{a}$ & $102 \mathrm{~b}$ & $21.7 \mathrm{abcd}$ & $7.3 \mathrm{a}$ & $1.2 \mathrm{a}$ \\
1229 & $23.3 \mathrm{a}$ & $41.0 \mathrm{a}$ & $6 \mathrm{~b}$ & $15.0 \mathrm{cde}$ & $5.0 \mathrm{a}$ & $1.5 \mathrm{a}$ \\
1245 & $3.7 \mathrm{a}$ & $1.2 \mathrm{a}$ & $19 \mathrm{~b}$ & $15.3 \mathrm{bcde}$ & $2.7 \mathrm{a}$ & $1.7 \mathrm{a}$ \\
1267 & $33.3 \mathrm{a}$ & $32.2 \mathrm{a}$ & $570 \mathrm{a}$ & $23.0 \mathrm{abc}$ & $5.0 \mathrm{a}$ & $1.7 \mathrm{a}$ \\
1448 & $25.0 \mathrm{a}$ & $11.5 \mathrm{a}$ & $157 \mathrm{~b}$ & $24.0 \mathrm{abc}$ & $4.0 \mathrm{a}$ & $1.0 \mathrm{a}$ \\
1588 & $34.3 \mathrm{a}$ & $29.5 \mathrm{a}$ & $142 \mathrm{~b}$ & $21.0 \mathrm{abcd}$ & $5.3 \mathrm{a}$ & $1.5 \mathrm{a}$ \\
1760 & $28.3 \mathrm{a}$ & $11.8 \mathrm{a}$ & $80 \mathrm{~b}$ & $22.0 \mathrm{abcd}$ & $4.0 \mathrm{a}$ & $1.3 \mathrm{a}$ \\
Reubens & $41.7 \mathrm{a}$ & $15.8 \mathrm{a}$ & $145 \mathrm{~b}$ & $24.3 \mathrm{ab}$ & $7.0 \mathrm{a}$ & $2.7 \mathrm{a}$ \\
Nugget & $33.3 \mathrm{a}$ & $8.3 \mathrm{a}$ & $65 \mathrm{~b}$ & $11.7 \mathrm{e}$ & $5.3 \mathrm{a}$ & $1.2 \mathrm{a}$ \\
\hline \hline
\end{tabular}

${ }^{\dagger}$ Means within columns followed by the same letter are not significantly different by Duncan's new multiple range test $(\mathrm{P} \leq 0.05)$. $\mathrm{n}=3$ for all means. 
Table A.14. Performance of selected alpine bluegrass in seeded provenance trial at Columbia Icefields in 1991. The trial was established in 1987.

\begin{tabular}{|c|c|c|c|c|c|c|}
\hline Line & $\begin{array}{c}\text { Cover } \\
(\%)\end{array}$ & $\begin{array}{c}\text { Number of Heads } \\
\left(\text { no. }^{-1}\right)\end{array}$ & $\begin{array}{l}\text { Seed Yield } \\
\left(\mathrm{mg} \mathrm{m}^{-1}\right)\end{array}$ & $\begin{array}{l}\text { Plant Height } \\
\text { (cm) }\end{array}$ & $\begin{array}{c}\text { Plant Width } \\
(\mathrm{cm})\end{array}$ & $\begin{array}{l}\text { Flag Leaf Length } \\
(\mathrm{cm})\end{array}$ \\
\hline 745 & $16.7 b c^{\dagger}$ & $21.0 \mathrm{a}$ & $33.7 \mathrm{ab}$ & $15.8 \mathrm{a}$ & $3.2 b$ & $1.3 \mathrm{a}$ \\
\hline 752 & $13.3 \mathrm{bc}$ & $15.3 \mathrm{abc}$ & $47.7 a$ & $14.8 \mathrm{a}$ & $3.8 \mathrm{~b}$ & $0.8 \mathrm{a}$ \\
\hline 864 & $15.0 \mathrm{bc}$ & $2.3 \mathrm{~d}$ & $2.3 \mathrm{c}$ & $13.2 \mathrm{a}$ & $2.3 b$ & $1.7 \mathrm{a}$ \\
\hline 907 & 23.3abc & $5.7 \mathrm{~cd}$ & $19.3 \mathrm{bc}$ & $12.0 \mathrm{a}$ & $1.5 b$ & $1.0 \mathrm{a}$ \\
\hline 1001 & $45.0 \mathrm{ab}$ & $1.3 \mathrm{~d}$ & $3.3 \mathrm{c}$ & $11.2 \mathrm{a}$ & $2.3 b$ & $1.2 \mathrm{a}$ \\
\hline 1003 & $20.7 \mathrm{abc}$ & $1.3 \mathrm{~d}$ & $7.3 \mathrm{bc}$ & $12.2 \mathrm{a}$ & $1.7 \mathrm{~b}$ & $0.7 \mathrm{a}$ \\
\hline 1079 & $8.3 c$ & $3.7 d$ & $12.7 \mathrm{bc}$ & $7.0 \mathrm{a}$ & $1.2 \mathrm{~b}$ & $0.3 a$ \\
\hline 1207 & $15.0 \mathrm{bc}$ & $9.0 \mathrm{bcd}$ & $17.7 \mathrm{bc}$ & $6.2 \mathrm{a}$ & $1.5 b$ & $0.5 a$ \\
\hline 1214 & $19.0 \mathrm{bc}$ & $4.7 d$ & $8.3 b c$ & $19.2 \mathrm{a}$ & $2.5 b$ & $0.8 \mathrm{a}$ \\
\hline 1229 & 29.0abc & $2.7 d$ & $7.7 \mathrm{bc}$ & $8.5 a$ & $1.3 \mathrm{~b}$ & $0.2 \mathrm{a}$ \\
\hline 1245 & $6.3 c$ & $0.3 d$ & $0.0 \mathrm{c}$ & $1.3 \mathrm{a}$ & $2.3 b$ & $0.2 \mathrm{a}$ \\
\hline 1267 & $31.7 \mathrm{abc}$ & $2.7 d$ & $10.0 \mathrm{bc}$ & $14.0 \mathrm{a}$ & $3.0 \mathrm{~b}$ & $0.5 \mathrm{a}$ \\
\hline 1448 & $22.3 \mathrm{abc}$ & $2.0 \mathrm{~d}$ & $4.3 c$ & $14.5 \mathrm{a}$ & $4.2 b$ & $0.5 \mathrm{a}$ \\
\hline 1588 & $40.0 \mathrm{abc}$ & $5.3 \mathrm{~cd}$ & $7.3 b c$ & $21.3 \mathrm{a}$ & $3.3 b$ & $0.8 \mathrm{a}$ \\
\hline 1760 & $31.7 \mathrm{abc}$ & $3.3 \mathrm{~d}$ & $6.7 b c$ & $15.0 \mathrm{a}$ & $3.7 \mathrm{~b}$ & $0.8 \mathrm{a}$ \\
\hline Reubens & $53.3 \mathrm{a}$ & $17.0 \mathrm{ab}$ & $0.0 \mathrm{c}$ & $22.7 a$ & $4.5 b$ & $2.7 \mathrm{a}$ \\
\hline Nugget & 28.3abc & $4.3 \mathrm{~d}$ & $44.7 a$ & $15.7 a$ & $8.7 a$ & $1.3 \mathrm{a}$ \\
\hline
\end{tabular}

${ }^{\dagger}$ Means within columns followed by the same letter are not significantly different by Duncan's new multiple range test $(\mathrm{P} \leq 0.05)$. $\mathrm{n}=3$ for all means. 
Table A.15. Performance of selected alpine bluegrass in seeded provenance trial at Columbia Icefields in 1992. The trial was established in 1987.

\begin{tabular}{rccccc}
\hline \hline Line & $\begin{array}{c}\text { Cover } \\
(\%)\end{array}$ & $\begin{array}{c}\text { Number of Heads } \\
\left(\text { no. } \mathrm{m}^{-1}\right)\end{array}$ & $\begin{array}{c}\text { Seed Yield } \\
\left(\mathrm{mg} \mathrm{m}^{1}\right)\end{array}$ & $\begin{array}{c}\text { Plant Height } \\
(\mathrm{cm})\end{array}$ & $\begin{array}{c}\text { Plant Width } \\
(\mathrm{cm})\end{array}$ \\
\hline 745 & $15.0 \mathrm{a}^{\dagger}$ & $24.0 \mathrm{a}$ & $28.3 \mathrm{ab}$ & $6.0 \mathrm{f}$ & $3.3 \mathrm{a}$ \\
752 & $15.0 \mathrm{a}$ & $18.7 \mathrm{ab}$ & $32.0 \mathrm{ab}$ & $6.0 \mathrm{f}$ & $3.3 \mathrm{a}$ \\
864 & $16.7 \mathrm{a}$ & $1.3 \mathrm{c}$ & $0.0 \mathrm{~b}$ & $15.5 \mathrm{bcde}$ & $2.7 \mathrm{a}$ \\
907 & $13.3 \mathrm{a}$ & $0.5 \mathrm{c}$ & $0.0 \mathrm{~b}$ & $13.0 \mathrm{cdef}$ & $4.0 \mathrm{a}$ \\
1001 & $33.3 \mathrm{a}$ & $4.5 \mathrm{bc}$ & $61.0 \mathrm{a}$ & $21.0 \mathrm{ab}$ & $4.5 \mathrm{a}$ \\
1003 & $18.3 \mathrm{a}$ & $1.3 \mathrm{c}$ & $3.0 \mathrm{~b}$ & $14.5 \mathrm{bcde}$ & $3.3 \mathrm{a}$ \\
1079 & $6.7 \mathrm{a}$ & $0.5 \mathrm{c}$ & $0.0 \mathrm{~b}$ & $16.0 \mathrm{bcde}$ & $2.0 \mathrm{a}$ \\
1207 & $13.3 \mathrm{a}$ & $0.0 \mathrm{c}$ & $0.0 \mathrm{~b}$ & - & $4.0 \mathrm{a}$ \\
1214 & $13.3 \mathrm{a}$ & $0.0 \mathrm{c}$ & $0.0 \mathrm{~b}$ & - & $3.3 \mathrm{a}$ \\
1229 & $22.3 \mathrm{a}$ & $2.5 \mathrm{c}$ & $3.0 \mathrm{~b}$ & $20.0 \mathrm{abc}$ & $2.5 \mathrm{a}$ \\
1245 & $8.3 \mathrm{a}$ & $4.0 \mathrm{bc}$ & $17.0 \mathrm{ab}$ & $9.0 \mathrm{ef}$ & $3.0 \mathrm{a}$ \\
1267 & $33.3 \mathrm{a}$ & $0.3 \mathrm{c}$ & $5.0 \mathrm{ab}$ & $15.0 \mathrm{bcde}$ & $4.0 \mathrm{a}$ \\
1448 & $22.3 \mathrm{a}$ & $7.7 \mathrm{bc}$ & $37.5 \mathrm{ab}$ & $25.0 \mathrm{a}$ & $3.7 \mathrm{a}$ \\
1588 & $36.7 \mathrm{a}$ & $9.0 \mathrm{abc}$ & $15.7 \mathrm{ab}$ & $18.3 \mathrm{abcd}$ & $6.0 \mathrm{a}$ \\
1760 & $27.3 \mathrm{a}$ & $7.0 \mathrm{bc}$ & $18.5 \mathrm{ab}$ & $18.5 \mathrm{abcd}$ & $3.0 \mathrm{a}$ \\
Reubens & $50.0 \mathrm{a}$ & $14.0 \mathrm{abc}$ & $22.7 \mathrm{ab}$ & $16.3 \mathrm{bcde}$ & $5.3 \mathrm{a}$ \\
Nugget & $28.3 \mathrm{a}$ & $1.3 \mathrm{c}$ & $21.0 \mathrm{ab}$ & $11.5 \mathrm{def}$ & $9.0 \mathrm{a}$ \\
\hline \hline
\end{tabular}

${ }^{\dagger}$ Means within columns followed by the same letter are not significantly different by Duncan's new multiple range test $(\mathrm{P} \leq 0.05)$. $\mathrm{n}=3$ for all means. 
Table A.16. Performance of selected alpine bluegrass in seeded provenance trial at Columbia Icefields in 1993. The trial was established in 1987.

\begin{tabular}{rccccc}
\hline \hline Line & $\begin{array}{c}\text { Cover } \\
(\%)\end{array}$ & $\begin{array}{c}\text { Number of Heads } \\
\left(\text { no. } \mathrm{m}^{-1}\right)\end{array}$ & $\begin{array}{c}\text { Seed Yield } \\
\left(\mathrm{mg} \mathrm{m}^{-1}\right)\end{array}$ & $\begin{array}{c}\text { Plant Height } \\
(\mathrm{cm})\end{array}$ & $\begin{array}{c}\text { Plant Width } \\
(\mathrm{cm})\end{array}$ \\
\hline 745 & $29.7 \mathrm{bcd} \mathrm{c}^{\dagger}$ & $4.2 \mathrm{a}$ & $12.5 \mathrm{a}$ & $10.0 \mathrm{a}$ & $4.7 \mathrm{a}$ \\
752 & $18.3 \mathrm{bcd}$ & $4.2 \mathrm{a}$ & $19.8 \mathrm{a}$ & $12.3 \mathrm{a}$ & $4.2 \mathrm{a}$ \\
864 & $8.3 \mathrm{~cd}$ & $0.0 \mathrm{~d}$ & $0.0 \mathrm{a}$ & - & $2.8 \mathrm{a}$ \\
907 & $28.3 \mathrm{bcd}$ & $0.2 \mathrm{~cd}$ & $1.0 \mathrm{a}$ & $5.3 \mathrm{a}$ & $2.8 \mathrm{a}$ \\
1001 & $55.0 \mathrm{ab}$ & $0.0 \mathrm{~d}$ & $0.0 \mathrm{a}$ & - & $3.5 \mathrm{a}$ \\
1003 & $33.0 \mathrm{bcd}$ & $0.5 \mathrm{~cd}$ & $5.2 \mathrm{a}$ & $7.3 \mathrm{a}$ & $3.3 \mathrm{a}$ \\
1079 & $5.0 \mathrm{~d}$ & $0.2 \mathrm{~cd}$ & $2.0 \mathrm{a}$ & $8.0 \mathrm{a}$ & $2.2 \mathrm{a}$ \\
1207 & $16.0 \mathrm{~cd}$ & $0.3 \mathrm{~cd}$ & $7.0 \mathrm{a}$ & $7.3 \mathrm{a}$ & $2.3 \mathrm{a}$ \\
1214 & $26.3 \mathrm{bcd}$ & $0.2 \mathrm{~cd}$ & $1.7 \mathrm{a}$ & $8.0 \mathrm{a}$ & $3.3 \mathrm{a}$ \\
1229 & $30.0 \mathrm{bcd}$ & $0.0 \mathrm{~d}$ & $0.0 \mathrm{a}$ & - & $1.3 \mathrm{a}$ \\
1245 & $4.0 \mathrm{~d}$ & $0.0 \mathrm{~d}$ & $0.0 \mathrm{a}$ & - & $2.8 \mathrm{a}$ \\
1267 & $33.3 \mathrm{bcd}$ & $0.5 \mathrm{~cd}$ & $3.3 \mathrm{a}$ & $6.3 \mathrm{a}$ & $5.3 \mathrm{a}$ \\
1448 & $28.3 \mathrm{bcd}$ & $0.8 \mathrm{~cd}$ & $8.3 \mathrm{a}$ & $5.0 \mathrm{a}$ & $3.0 \mathrm{a}$ \\
1588 & $50.0 \mathrm{abc}$ & $3.5 \mathrm{ab}$ & $19.5 \mathrm{a}$ & $21.0 \mathrm{a}$ & $5.0 \mathrm{a}$ \\
1760 & $38.0 \mathrm{bcd}$ & $2.2 \mathrm{bc}$ & $14.5 \mathrm{a}$ & $18.3 \mathrm{a}$ & $3.2 \mathrm{a}$ \\
Reubens & $53.3 \mathrm{ab}$ & $2.0 \mathrm{bcd}$ & $0.0 \mathrm{a}$ & $15.0 \mathrm{a}$ & $4.0 \mathrm{a}$ \\
Nugget & $83.3 \mathrm{a}$ & $0.2 \mathrm{~cd}$ & $0.0 \mathrm{a}$ & $3.7 \mathrm{a}$ & $4.8 \mathrm{a}$ \\
\hline \hline
\end{tabular}

${ }^{\dagger}$ Means within columns followed by the same letter are not significantly different by Duncan's new multiple range test $(\mathrm{P} \leq 0.05) . \mathrm{n}=3$ for all means. 
Table A.17. Performance of selected alpine bluegrass in seeded provenance trial at Columbia Icefields in 1994. The trial was established in 1987.

\begin{tabular}{rccccc}
\hline \hline Line & $\begin{array}{c}\text { Cover } \\
(\%)\end{array}$ & $\begin{array}{c}\text { Number of Heads } \\
\left(\text { no. } \mathrm{m}^{-1}\right)\end{array}$ & $\begin{array}{c}\text { Seed Yield } \\
\left(\mathrm{mg} \mathrm{m}^{-1}\right)\end{array}$ & $\begin{array}{c}\text { Plant Height } \\
(\mathrm{cm})\end{array}$ & $\begin{array}{c}\text { Plant Width } \\
(\mathrm{cm})\end{array}$ \\
\hline 745 & $30.0 \mathrm{bc} \mathrm{c}^{\dagger}$ & $3.0 \mathrm{bc}$ & $9.2 \mathrm{~b}$ & $8.7 \mathrm{efg}$ & $4.3 \mathrm{a}$ \\
752 & $21.7 \mathrm{bc}$ & $4.8 \mathrm{ab}$ & $34.7 \mathrm{~b}$ & $7.0 \mathrm{fg}$ & $5.5 \mathrm{a}$ \\
864 & $8.3 \mathrm{bc}$ & $0.0 \mathrm{c}$ & $0.0 \mathrm{~b}$ & - & $4.0 \mathrm{a}$ \\
907 & $8.3 \mathrm{bc}$ & $0.2 \mathrm{c}$ & $33.2 \mathrm{~b}$ & $15.0 \mathrm{abcdef}$ & $3.0 \mathrm{a}$ \\
1001 & $18.3 \mathrm{bc}$ & $0.3 \mathrm{c}$ & $4.0 \mathrm{~b}$ & $12.0 \mathrm{cdefg}$ & $5.0 \mathrm{a}$ \\
1003 & $15.0 \mathrm{bc}$ & $0.0 \mathrm{c}$ & $0.0 \mathrm{~b}$ & - & $3.3 \mathrm{a}$ \\
1079 & $1.7 \mathrm{c}$ & $0.0 \mathrm{c}$ & $0.0 \mathrm{~b}$ & - & $2.0 \mathrm{a}$ \\
1207 & $3.3 \mathrm{c}$ & $0.2 \mathrm{c}$ & $1.0 \mathrm{~b}$ & $18.0 \mathrm{abcde}$ & $3.5 \mathrm{a}$ \\
1214 & $18.3 \mathrm{bc}$ & $0.2 \mathrm{c}$ & $0.3 \mathrm{~b}$ & $13.0 \mathrm{bcdef}$ & $3.5 \mathrm{a}$ \\
1229 & $30.0 \mathrm{bc}$ & $0.2 \mathrm{c}$ & $17.2 \mathrm{~b}$ & $22.0 \mathrm{ab}$ & $3.0 \mathrm{a}$ \\
1245 & $3.3 \mathrm{c}$ & $0.3 \mathrm{c}$ & $0.3 \mathrm{~b}$ & $3.0 \mathrm{~g}$ & $4.0 \mathrm{a}$ \\
1267 & $50.0 \mathrm{ab}$ & $0.2 \mathrm{c}$ & $0.7 \mathrm{~b}$ & $10.0 \mathrm{cdefg}$ & $5.7 \mathrm{a}$ \\
1448 & $30.0 \mathrm{bc}$ & $3.0 \mathrm{bc}$ & $65.3 \mathrm{ab}$ & $23.5 \mathrm{a}$ & $8.5 \mathrm{a}$ \\
1588 & $53.3 \mathrm{ab}$ & $6.8 \mathrm{a}$ & $124.3 \mathrm{a}$ & $18.7 \mathrm{abcd}$ & $5.7 \mathrm{a}$ \\
1760 & $8.3 \mathrm{bc}$ & $2.8 \mathrm{bc}$ & $48.0 \mathrm{ab}$ & $19.0 \mathrm{abc}$ & $6.0 \mathrm{a}$ \\
Reubens & $33.3 \mathrm{bc}$ & $0.2 \mathrm{c}$ & $3.8 \mathrm{~b}$ & $24.0 \mathrm{a}$ & $8.5 \mathrm{a}$ \\
Nugget & $80.0 \mathrm{a}$ & $0.3 \mathrm{c}$ & $3.8 \mathrm{~b}$ & $9.0 \mathrm{defg}$ & $9.3 \mathrm{a}$ \\
\hline \hline
\end{tabular}

${ }^{\dagger}$ Means within columns followed by the same letter are not significantly different by Duncan's new multiple range test $(\mathrm{P} \leq 0.05)$. $\mathrm{n}=3$ for all means. 







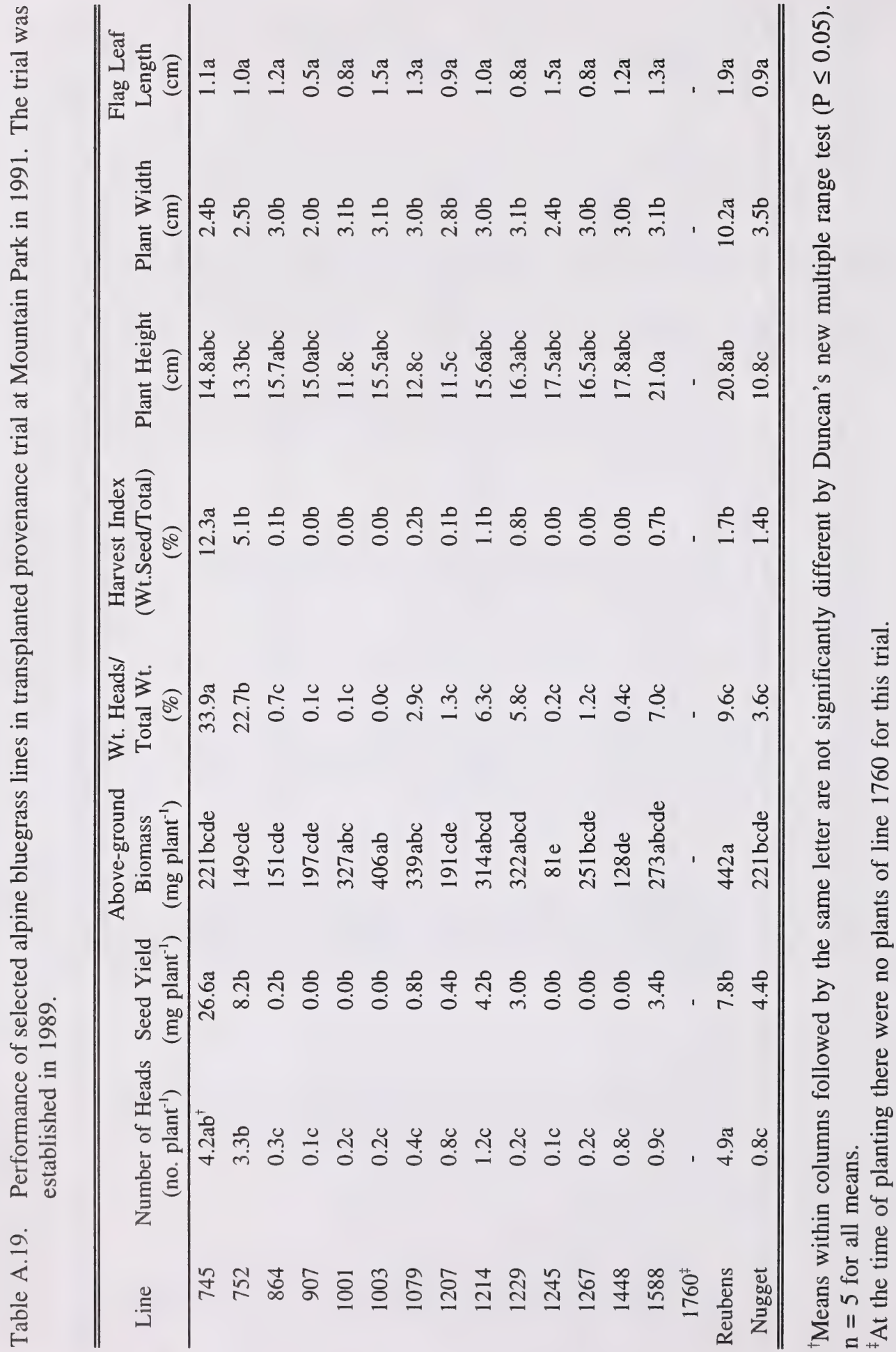


Table A.20. Performance of selected alpine bluegrass in transplanted provenance trial 2 at Mountain Park in 1992. The trial was established in 1989.

\begin{tabular}{rcccc}
\hline \hline \multicolumn{1}{c}{ Line } & $\begin{array}{c}\text { Number of Heads } \\
\left(\text { no. plant }{ }^{-1}\right)\end{array}$ & $\begin{array}{c}\text { Seed Yield } \\
\left(\text { mg plant }^{-1}\right)\end{array}$ & $\begin{array}{c}\text { Plant Height } \\
(\mathrm{cm})\end{array}$ & $\begin{array}{c}\text { Plant Width } \\
(\mathrm{cm})\end{array}$ \\
\hline 745 & $1.8 \mathrm{~cd}^{\dagger}$ & $4.1 \mathrm{a}$ & $9.8 \mathrm{bcd}$ & $2.8 \mathrm{c}$ \\
752 & $2.1 \mathrm{~cd}$ & $8.9 \mathrm{a}$ & $9.0 \mathrm{~cd}$ & $2.8 \mathrm{c}$ \\
864 & $0.8 \mathrm{~d}$ & $3.7 \mathrm{a}$ & $5.8 \mathrm{~d}$ & $2.2 \mathrm{c}$ \\
907 & $1.6 \mathrm{~cd}$ & $18.6 \mathrm{a}$ & $13.6 \mathrm{abcd}$ & $3.0 \mathrm{c}$ \\
1001 & $1.3 \mathrm{~cd}$ & $6.3 \mathrm{a}$ & $12.2 \mathrm{bcd}$ & $3.0 \mathrm{c}$ \\
1003 & $1.8 \mathrm{~cd}$ & $75.0 \mathrm{a}$ & $17.2 \mathrm{abcd}$ & $4.4 \mathrm{c}$ \\
1079 & $1.0 \mathrm{~d}$ & $27.3 \mathrm{a}$ & $16.4 \mathrm{abcd}$ & $4.2 \mathrm{c}$ \\
1207 & $3.4 \mathrm{abc}$ & $40.0 \mathrm{a}$ & $19.4 \mathrm{abc}$ & $3.8 \mathrm{c}$ \\
1214 & $4.3 \mathrm{ab}$ & $49.8 \mathrm{a}$ & $22.0 \mathrm{ab}$ & $4.2 \mathrm{c}$ \\
1229 & $1.4 \mathrm{~cd}$ & $11.6 \mathrm{a}$ & $14.4 \mathrm{abcd}$ & $3.8 \mathrm{c}$ \\
1245 & $2.4 \mathrm{bcd}$ & $27.0 \mathrm{a}$ & $10.4 \mathrm{bcd}$ & $4.6 \mathrm{c}$ \\
1267 & $1.0 \mathrm{~d}$ & $6.0 \mathrm{a}$ & $8.5 \mathrm{~cd}$ & $4.2 \mathrm{c}$ \\
1448 & $1.1 \mathrm{~d}$ & $10.2 \mathrm{a}$ & $16.3 \mathrm{abcd}$ & $3.7 \mathrm{c}$ \\
1588 & $1.2 \mathrm{~cd}$ & $11.4 \mathrm{a}$ & $9.0 \mathrm{~cd}$ & $3.6 \mathrm{c}$ \\
$1760^{\ddagger}$ & - & - & - & - \\
Reubens & $5.0 \mathrm{a}$ & $11.2 \mathrm{a}$ & $24.8 \mathrm{a}$ & $19.0 \mathrm{a}$ \\
Nugget & $1.5 \mathrm{~cd}$ & $15.4 \mathrm{a}$ & $8.4 \mathrm{~cd}$ & $12.4 \mathrm{~b}$ \\
\hline \hline
\end{tabular}

${ }^{\dagger}$ Means within columns followed by the same letter are not significantly different by Duncan's new multiple range test $(\mathrm{P} \leq 0.05)$. $\mathrm{n}=5$ for all means.

${ }^{\ddagger}$ At the time of planting there were no plants of line 1760 for this trial. 
Table A.21. Performance of selected alpine bluegrass in transplanted provenance trial at Mountain Park in 1993. The trial was established in 1989.

\begin{tabular}{rcccc}
\hline \hline \multicolumn{1}{c}{ Line } & $\begin{array}{c}\text { Number of Heads } \\
\left(\text { no. plant }{ }^{-1}\right)\end{array}$ & $\begin{array}{c}\text { Seed Yield } \\
\left(\mathrm{mg} \mathrm{plant}^{-1}\right)\end{array}$ & $\begin{array}{c}\text { Plant Height } \\
(\mathrm{cm})\end{array}$ & $\begin{array}{c}\text { Plant Width } \\
(\mathrm{cm})\end{array}$ \\
\hline 745 & $0.4 \mathrm{a}^{\dagger}$ & $1.7 \mathrm{a}$ & $10.5 \mathrm{~cd}$ & $3.4 \mathrm{~b}$ \\
752 & $0.6 \mathrm{a}$ & $2.5 \mathrm{a}$ & $11.7 \mathrm{~cd}$ & $3.6 \mathrm{~b}$ \\
864 & $0.3 \mathrm{a}$ & $0.4 \mathrm{a}$ & $12.0 \mathrm{bcd}$ & $3.8 \mathrm{~b}$ \\
907 & $0.4 \mathrm{a}$ & $2.3 \mathrm{a}$ & $14.0 \mathrm{abcd}$ & $4.6 \mathrm{~b}$ \\
1001 & $0.4 \mathrm{a}$ & $6.0 \mathrm{a}$ & $18.0 \mathrm{ab}$ & $4.4 \mathrm{~b}$ \\
1003 & $0.9 \mathrm{a}$ & $14.9 \mathrm{a}$ & $19.0 \mathrm{a}$ & $5.4 \mathrm{~b}$ \\
1079 & $0.1 \mathrm{a}$ & $1.7 \mathrm{a}$ & $18.0 \mathrm{ab}$ & $5.2 \mathrm{~b}$ \\
1207 & $1.0 \mathrm{a}$ & $7.1 \mathrm{a}$ & $20.1 \mathrm{a}$ & $4.0 \mathrm{~b}$ \\
1214 & $1.5 \mathrm{a}$ & $15.1 \mathrm{a}$ & $16.5 \mathrm{abc}$ & $5.0 \mathrm{~b}$ \\
1229 & $0.2 \mathrm{a}$ & $2.0 \mathrm{a}$ & $19.0 \mathrm{a}$ & $4.0 \mathrm{~b}$ \\
1245 & $2.3 \mathrm{a}$ & $40.2 \mathrm{a}$ & $20.3 \mathrm{a}$ & $6.0 \mathrm{~b}$ \\
1267 & $0.0 \mathrm{a}$ & $0.0 \mathrm{a}$ & - & $5.2 \mathrm{~b}$ \\
1448 & $0.4 \mathrm{a}$ & $1.3 \mathrm{a}$ & $19.3 \mathrm{a}$ & $5.7 \mathrm{~b}$ \\
1588 & $0.4 \mathrm{a}$ & $5.6 \mathrm{a}$ & $20.3 \mathrm{a}$ & $5.0 \mathrm{~b}$ \\
$1760^{\ddagger}$ & - & - & - & - \\
Reubens & $1.7 \mathrm{a}$ & $0.3 \mathrm{a}$ & $18.8 \mathrm{a}$ & $22.9 \mathrm{a}$ \\
Nugget & $1.1 \mathrm{a}$ & $3.3 \mathrm{a}$ & $9.4 \mathrm{~d}$ & $22.0 \mathrm{a}$ \\
\hline \hline
\end{tabular}

${ }^{\dagger}$ Means within columns followed by the same letter are not significantly different by Duncan's new multiple range test $(\mathrm{P} \leq 0.05)$. $\mathrm{n}=5$ for all means.

${ }^{\ddagger}$ At the time of planting there were no plants of line 1760 for this trial. 
Table A.22. Performance of selected alpine bluegrass in transplanted provenance trial at Mountain Park in 1994. The trial was established in 1989.

\begin{tabular}{rcccc}
\hline \hline \multicolumn{1}{c}{ Line } & $\begin{array}{c}\text { Number of Heads } \\
\left(\text { no. plant }{ }^{-1}\right)\end{array}$ & $\begin{array}{c}\text { Seed Yield } \\
\left(\text { mg plant }^{-1}\right)\end{array}$ & $\begin{array}{c}\text { Plant Height } \\
(\mathrm{cm})\end{array}$ & $\begin{array}{c}\text { Plant Width } \\
(\mathrm{cm})\end{array}$ \\
\hline 745 & $0.3 \mathrm{ab}^{\dagger}$ & $2.4 \mathrm{a}$ & $6.3 \mathrm{bc}$ & $3.4 \mathrm{~b}$ \\
752 & $0.6 \mathrm{ab}$ & $10.4 \mathrm{a}$ & $11.7 \mathrm{abc}$ & $3.6 \mathrm{~b}$ \\
864 & $0.3 \mathrm{~b}$ & $4.4 \mathrm{a}$ & $2.4 \mathrm{c}$ & $3.8 \mathrm{~b}$ \\
907 & $0.3 \mathrm{~b}$ & $16.8 \mathrm{a}$ & $14.0 \mathrm{ab}$ & $4.6 \mathrm{~b}$ \\
1001 & $0.4 \mathrm{ab}$ & $5.2 \mathrm{a}$ & $10.8 \mathrm{abc}$ & $4.4 \mathrm{~b}$ \\
1003 & $0.9 \mathrm{ab}$ & $50.6 \mathrm{a}$ & $15.2 \mathrm{ab}$ & $5.4 \mathrm{~b}$ \\
1079 & $0.1 \mathrm{~b}$ & $9.0 \mathrm{a}$ & $7.2 \mathrm{bc}$ & $5.2 \mathrm{~b}$ \\
1207 & $1.0 \mathrm{ab}$ & $11.2 \mathrm{a}$ & $16.1 \mathrm{ab}$ & $4.0 \mathrm{~b}$ \\
1214 & $1.5 \mathrm{ab}$ & $58.6 \mathrm{a}$ & $16.5 \mathrm{ab}$ & $5.0 \mathrm{~b}$ \\
1229 & $0.2 \mathrm{~b}$ & $10.6 \mathrm{a}$ & $7.6 \mathrm{bc}$ & $4.0 \mathrm{~b}$ \\
1245 & $2.3 \mathrm{a}$ & $122.4 \mathrm{a}$ & $8.1 \mathrm{bc}$ & $6.0 \mathrm{~b}$ \\
1267 & $0.0 \mathrm{~b}$ & $18.3 \mathrm{a}$ & - & $5.2 \mathrm{~b}$ \\
1448 & $0.3 \mathrm{ab}$ & $1.8 \mathrm{a}$ & $9.6 \mathrm{abc}$ & $4.3 \mathrm{~b}$ \\
1588 & $0.4 \mathrm{ab}$ & $9.4 \mathrm{a}$ & $12.2 \mathrm{abc}$ & $5.0 \mathrm{~b}$ \\
$1760^{\ddagger}$ & - & - & - & - \\
Reubens & $1.7 \mathrm{ab}$ & $13.2 \mathrm{a}$ & $18.8 \mathrm{a}$ & $22.9 \mathrm{a}$ \\
Nugget & $1.1 \mathrm{ab}$ & $2.0 \mathrm{a}$ & $9.4 \mathrm{abc}$ & $22.0 \mathrm{a}$ \\
\hline \hline
\end{tabular}

${ }^{\dagger}$ Means within columns followed by the same letter are not significantly different by Duncan's new multiple range test $(\mathrm{P} \leq 0.05)$. $\mathrm{n}=5$ for all means.

${ }^{\ddagger}$ At the time of planting there were no plants of line 1760 for this trial. 
Table A.23. Performance of selected alpine bluegrass lines in transplanted provenance trial at Sunshine Village in 1989. The trial was established in 1987.

\begin{tabular}{rcccc}
\hline \hline \multicolumn{1}{c}{ Line } & $\begin{array}{c}\text { Number of Heads } \\
\left(\text { no. plant }{ }^{-1}\right)\end{array}$ & $\begin{array}{c}\text { Above-ground } \\
\text { Biomass } \\
\left(\text { (m plant }^{-1}\right)\end{array}$ & $\begin{array}{c}\text { Plant Height } \\
(\mathrm{cm})\end{array}$ & $\begin{array}{c}\text { Flag Leaf Length } \\
(\mathrm{cm})\end{array}$ \\
\hline 745 & $3.1 \mathrm{ab}^{\dagger}$ & $324 \mathrm{a}$ & $6.6 \mathrm{~d}$ & $1.6 \mathrm{cdef}$ \\
752 & $3.5 \mathrm{a}$ & $397 \mathrm{a}$ & $7.0 \mathrm{~d}$ & $2.9 \mathrm{abc}$ \\
864 & $3.0 \mathrm{abc}$ & $440 \mathrm{a}$ & $15.3 \mathrm{ab}$ & $1.1 \mathrm{ef}$ \\
907 & $0.3 \mathrm{~d}$ & $204 \mathrm{a}$ & $8.5 \mathrm{~d}$ & $1.0 \mathrm{f}$ \\
1001 & $1.4 \mathrm{abcd}$ & $470 \mathrm{a}$ & $13.9 \mathrm{abc}$ & $2.1 \mathrm{cdef}$ \\
1003 & $1.1 \mathrm{bcd}$ & $394 \mathrm{a}$ & $10.2 \mathrm{~cd}$ & $1.7 \mathrm{cdef}$ \\
1079 & $1.4 \mathrm{abcd}$ & $390 \mathrm{a}$ & $11.4 \mathrm{bcd}$ & $1.4 \mathrm{def}$ \\
1207 & $1.4 \mathrm{abcd}$ & $286 \mathrm{a}$ & $10.3 \mathrm{~cd}$ & $1.8 \mathrm{cdef}$ \\
1214 & $1.5 \mathrm{abcd}$ & $360 \mathrm{a}$ & $9.1 \mathrm{~d}$ & $1.3 \mathrm{ef}$ \\
1229 & $2.1 \mathrm{abcd}$ & $326 \mathrm{a}$ & $17.9 \mathrm{a}$ & $1.3 \mathrm{def}$ \\
1245 & $1.9 \mathrm{abcd}$ & $313 \mathrm{a}$ & $15.6 \mathrm{ab}$ & $1.9 \mathrm{cdef}$ \\
1267 & $0.3 \mathrm{~d}$ & $376 \mathrm{a}$ & $7.7 \mathrm{~d}$ & $0.8 \mathrm{f}$ \\
1448 & $1.6 \mathrm{abcd}$ & $463 \mathrm{a}$ & $17.3 \mathrm{a}$ & $3.5 \mathrm{ab}$ \\
1588 & $1.1 \mathrm{bcd}$ & $318 \mathrm{a}$ & $18.0 \mathrm{a}$ & $2.7 \mathrm{bcd}$ \\
1760 & $2.1 \mathrm{abcd}$ & $390 \mathrm{a}$ & $16.0 \mathrm{ab}$ & $4.0 \mathrm{a}$ \\
Reubens & $1.1 \mathrm{bcd}$ & $265 \mathrm{a}$ & $17.5 \mathrm{a}$ & $4.0 \mathrm{a}$ \\
Nugget & $0.8 \mathrm{~cd}$ & $495 \mathrm{a}$ & $15.0 \mathrm{ab}$ & $2.5 \mathrm{bcde}$ \\
\hline \hline
\end{tabular}

†Means within columns followed by the same letter are not significantly different by Duncan's new multiple range test $(\mathrm{P} \leq 0.05)$. $\mathrm{n}=5$ for all means. 
Table A.24. Performance of selected alpine bluegrass lines in transplanted provenance trial at Sunshine Village in 1990. The trial was established in 1987.

\begin{tabular}{rccccc}
\hline \hline Line & $\begin{array}{c}\text { Number of Heads } \\
\left(\text { no. plant }{ }^{-1}\right)\end{array}$ & $\begin{array}{c}\text { Wt. Heads/ } \\
\text { Total Wt. } \\
(\%)\end{array}$ & $\begin{array}{c}\text { Plant Height } \\
(\mathrm{cm})\end{array}$ & $\begin{array}{c}\text { Plant Width } \\
(\mathrm{cm})\end{array}$ & $\begin{array}{c}\text { Flag Leaf } \\
\text { Length } \\
(\mathrm{cm})\end{array}$ \\
\hline 745 & $5.8 \mathrm{a}^{\dagger}$ & $33.5 \mathrm{a}$ & $4.8 \mathrm{c}$ & $5.8 \mathrm{a}$ & $1.7 \mathrm{bc}$ \\
752 & $5.5 \mathrm{a}$ & $26.5 \mathrm{ab}$ & $5.7 \mathrm{bc}$ & $4.9 \mathrm{a}$ & $1.4 \mathrm{bcd}$ \\
864 & $2.4 \mathrm{~b}$ & $18.5 \mathrm{bcd}$ & $12.6 \mathrm{a}$ & $5.2 \mathrm{a}$ & $1.1 \mathrm{bcd}$ \\
907 & $1.4 \mathrm{~b}$ & $15.7 \mathrm{bcde}$ & $10.1 \mathrm{abc}$ & $3.7 \mathrm{a}$ & $0.8 \mathrm{~cd}$ \\
1001 & $1.5 \mathrm{~b}$ & $16.1 \mathrm{bcd}$ & $8.5 \mathrm{abc}$ & $5.5 \mathrm{a}$ & $1.1 \mathrm{bcd}$ \\
1003 & $1.0 \mathrm{~b}$ & $12.5 \mathrm{cde}$ & $6.1 \mathrm{bc}$ & $4.1 \mathrm{a}$ & $0.9 \mathrm{bcd}$ \\
1079 & $1.2 \mathrm{~b}$ & $14.2 \mathrm{cde}$ & $6.2 \mathrm{bc}$ & $6.9 \mathrm{a}$ & $0.8 \mathrm{~cd}$ \\
1207 & $1.9 \mathrm{~b}$ & $19.5 \mathrm{bcd}$ & $6.6 \mathrm{bc}$ & $4.1 \mathrm{a}$ & $1.7 \mathrm{bc}$ \\
1214 & $2.0 \mathrm{~b}$ & $16.7 \mathrm{bcd}$ & $7.5 \mathrm{abc}$ & $5.1 \mathrm{a}$ & $1.4 \mathrm{bcd}$ \\
1229 & $1.2 \mathrm{~b}$ & $13.2 \mathrm{cde}$ & $12.5 \mathrm{a}$ & $4.5 \mathrm{a}$ & $1.1 \mathrm{bcd}$ \\
1245 & $1.8 \mathrm{~b}$ & $14.7 \mathrm{bcde}$ & $8.6 \mathrm{abc}$ & $4.8 \mathrm{a}$ & $0.8 \mathrm{~cd}$ \\
1267 & $0.9 \mathrm{~b}$ & $9.4 \mathrm{de}$ & $8.9 \mathrm{abc}$ & $5.4 \mathrm{a}$ & $0.9 \mathrm{bcd}$ \\
1448 & $2.6 \mathrm{~b}$ & $24.2 \mathrm{abc}$ & $11.1 \mathrm{ab}$ & $6.4 \mathrm{a}$ & $2.8 \mathrm{a}$ \\
1588 & $2.6 \mathrm{~b}$ & $15.1 \mathrm{bcde}$ & $10.6 \mathrm{abc}$ & $6.1 \mathrm{a}$ & $1.3 \mathrm{bcd}$ \\
1760 & $2.1 \mathrm{~b}$ & $15.7 \mathrm{bcde}$ & $11.2 \mathrm{ab}$ & $5.6 \mathrm{a}$ & $1.8 \mathrm{~b}$ \\
Reubens & $1.5 \mathrm{~b}$ & $3.9 \mathrm{e}$ & $8.0 \mathrm{abc}$ & $5.5 \mathrm{a}$ & $0.5 \mathrm{~d}$ \\
Nugget & $1.9 \mathrm{~b}$ & $12.2 \mathrm{cde}$ & $11.0 \mathrm{ab}$ & $6.8 \mathrm{a}$ & $1.9 \mathrm{~b}$ \\
\hline \hline
\end{tabular}

${ }^{\dagger}$ Means within columns followed by the same letter are not significantly different by Duncan's new multiple range test $(\mathrm{P} \leq 0.05)$. $\mathrm{n}=5$ for all means. 
Table A.25. Performance of selected alpine bluegrass lines in transplanted provenance trial at Sunshine Village in 1991. The trial was established in 1987.

\begin{tabular}{rcc}
\hline \hline \multicolumn{1}{c}{ Line } & $\begin{array}{c}\text { Number of Heads } \\
(\text { no. plant })^{-1}\end{array}$ & $\begin{array}{c}\text { Plant Height } \\
(\mathrm{cm})\end{array}$ \\
\hline 745 & $1.8 \mathrm{ab}^{\dagger}$ & $5.0 \mathrm{e}$ \\
752 & $2.9 \mathrm{a}$ & $5.0 \mathrm{e}$ \\
864 & $1.4 \mathrm{bc}$ & $10.0 \mathrm{abc}$ \\
907 & $0.2 \mathrm{c}$ & $8.0 \mathrm{bcde}$ \\
1001 & $0.4 \mathrm{bc}$ & $8.4 \mathrm{bcd}$ \\
1003 & $0.4 \mathrm{bc}$ & $7.8 \mathrm{cde}$ \\
1079 & $0.5 \mathrm{bc}$ & $8.5 \mathrm{bcd}$ \\
1207 & $0.2 \mathrm{c}$ & $6.8 \mathrm{de}$ \\
1214 & $0.4 \mathrm{bc}$ & $7.3 \mathrm{cde}$ \\
1229 & $0.2 \mathrm{c}$ & $10.3 \mathrm{abc}$ \\
1245 & $0.6 \mathrm{bc}$ & $8.0 \mathrm{bcde}$ \\
1267 & $0.4 \mathrm{c}$ & $8.4 \mathrm{bcd}$ \\
1448 & $1.8 \mathrm{ab}$ & $13.0 \mathrm{a}$ \\
1588 & $0.9 \mathrm{bc}$ & $10.4 \mathrm{abc}$ \\
1760 & $1.2 \mathrm{bc}$ & $11.0 \mathrm{ab}$ \\
Reubens & $0.7 \mathrm{bc}$ & $11.0 \mathrm{ab}$ \\
Nugget & $0.0 \mathrm{c}$ & - \\
\hline \hline
\end{tabular}

${ }^{\dagger}$ Means within columns followed by the same letter are not significantly different by Duncan's new multiple range test $(\mathrm{P} \leq 0.05)$. $\mathrm{n}=5$ for all means. 
Table A.26. Performance of selected alpine bluegrass lines in transplanted provenance trial at Sunshine Village in 1993. The trial was established in 1987.

\begin{tabular}{|c|c|c|c|c|}
\hline Line & $\begin{array}{c}\text { Number of Heads } \\
\left(\text { no. plant }{ }^{-1}\right)\end{array}$ & $\begin{array}{l}\text { Above-ground } \\
\text { Biomass } \\
\left(\text { mg plant }^{-1}\right)\end{array}$ & $\begin{array}{l}\text { Plant Height } \\
(\mathrm{cm})\end{array}$ & $\begin{array}{c}\text { Plant Width } \\
(\mathrm{cm})\end{array}$ \\
\hline 745 & $0.9 a^{\dagger}$ & $119 a$ & $9.0 \mathrm{a}$ & $4.2 a$ \\
\hline 752 & $1.4 \mathrm{a}$ & $109 a$ & $9.0 \mathrm{a}$ & $4.0 \mathrm{a}$ \\
\hline 864 & $0.7 \mathrm{a}$ & $97 a$ & $10.2 \mathrm{a}$ & $4.2 \mathrm{a}$ \\
\hline 907 & $0.9 \mathrm{a}$ & $133 a$ & $11.4 \mathrm{a}$ & $4.6 a$ \\
\hline 1001 & $0.8 \mathrm{a}$ & $147 a$ & $10.6 a$ & $4.0 \mathrm{a}$ \\
\hline 1003 & $0.7 \mathrm{a}$ & $98 \mathrm{a}$ & $8.6 a$ & $4.8 \mathrm{a}$ \\
\hline 1079 & $0.8 \mathrm{a}$ & $114 a$ & $12.2 \mathrm{a}$ & $5.0 \mathrm{a}$ \\
\hline 1207 & $0.9 \mathrm{a}$ & $99 a$ & $9.0 \mathrm{a}$ & $5.8 \mathrm{a}$ \\
\hline 1214 & $1.1 \mathrm{a}$ & $82 a$ & $7.6 a$ & $6.2 \mathrm{a}$ \\
\hline 1229 & $0.8 \mathrm{a}$ & $97 a$ & $7.6 a$ & $4.0 \mathrm{a}$ \\
\hline 1245 & $0.7 \mathrm{a}$ & $89 a$ & $9.5 \mathrm{a}$ & $4.0 \mathrm{a}$ \\
\hline 1267 & $0.7 \mathrm{a}$ & $106 a$ & $11.0 \mathrm{a}$ & $3.9 \mathrm{a}$ \\
\hline 1448 & $0.8 \mathrm{a}$ & $131 \mathrm{a}$ & $11.8 \mathrm{a}$ & $4.8 \mathrm{a}$ \\
\hline 1588 & $0.9 a$ & $127 \mathrm{a}$ & $9.0 \mathrm{a}$ & $4.2 \mathrm{a}$ \\
\hline 1760 & $1.0 \mathrm{a}$ & $107 a$ & $9.2 \mathrm{a}$ & $5.4 a$ \\
\hline Reubens & $1.2 \mathrm{a}$ & $40 a$ & $8.5 a$ & $3.5 \mathrm{a}$ \\
\hline Nugget & $0.6 \mathrm{a}$ & $64 a$ & $8.5 \mathrm{a}$ & $5.0 \mathrm{a}$ \\
\hline
\end{tabular}

${ }^{\dagger}$ Means within columns followed by the same letter are not significantly different by Duncan's new multiple range test $(\mathrm{P} \leq 0.05)$. $\mathrm{n}=5$ for all means. 


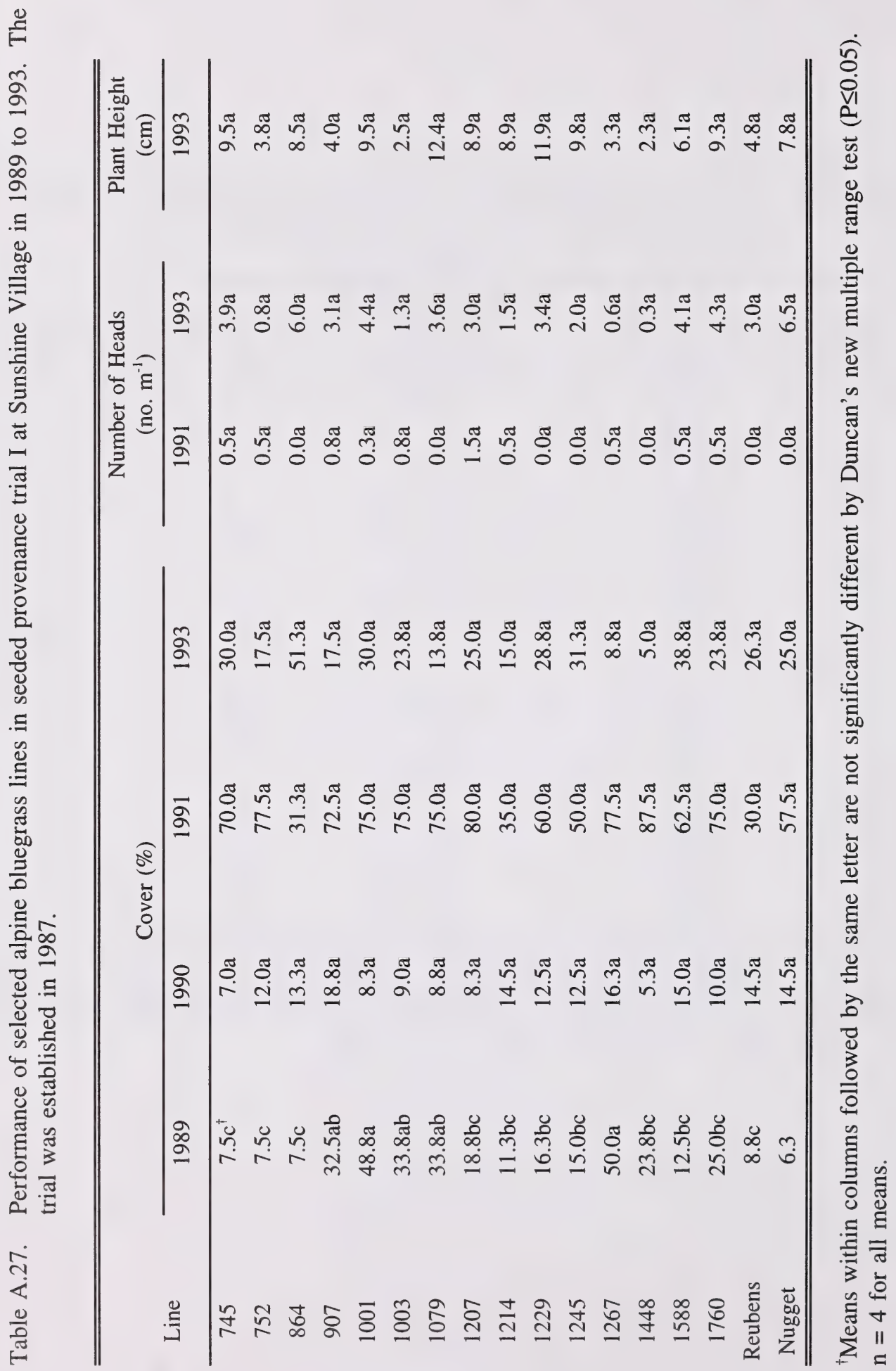







Table A.29. Performance of selected alpine bluegrass lines in transplanted provenance trial at Vegreville in 1988. The trial was established in 1987.

\begin{tabular}{rccccc}
\hline \hline \multicolumn{1}{c}{ Line } & $\begin{array}{c}\text { Number of Heads } \\
\left(\text { no. plant }{ }^{-1}\right)\end{array}$ & $\begin{array}{c}\text { Seed Yield } \\
\left(\mathrm{g} \mathrm{plant}^{-1}\right)\end{array}$ & $\begin{array}{c}\text { Time to } \\
\text { Maturity } \\
\left(\text { days }{ }^{\dagger}\right)\end{array}$ & $\begin{array}{c}1000 \\
\text { Seed Wt. } \\
(\mathrm{mg})\end{array}$ & $\begin{array}{c}\text { Above-ground } \\
\text { Biomass } \\
\left(\mathrm{g} \mathrm{plant}^{-1}\right)\end{array}$ \\
\hline 745 & $100.4 \mathrm{ab}^{\ddagger}$ & $1.7 \mathrm{bc}$ & $86 \mathrm{ab}$ & $431 \mathrm{bcde}$ & $24.2 \mathrm{ef}$ \\
752 & $130.0 \mathrm{a}$ & $1.4 \mathrm{bc}$ & $87 \mathrm{a}$ & $374 \mathrm{de}$ & $22.1 \mathrm{f}$ \\
864 & $46.9 \mathrm{cdef}$ & $2.4 \mathrm{abc}$ & $63 \mathrm{gh}$ & $398 \mathrm{de}$ & $43.4 \mathrm{bcd}$ \\
907 & $28.8 \mathrm{def}$ & $1.8 \mathrm{bc}$ & $62 \mathrm{~h}$ & $383 \mathrm{de}$ & $27.6 \mathrm{def}$ \\
1001 & $22.9 \mathrm{f}$ & $3.9 \mathrm{abc}$ & $70 \mathrm{efg}$ & $440 \mathrm{bcde}$ & $35.7 \mathrm{cdef}$ \\
1003 & $38.9 \mathrm{cdef}$ & $3.7 \mathrm{abc}$ & $69 \mathrm{fgh}$ & $453 \mathrm{abcd}$ & $36.7 \mathrm{bcdef}$ \\
1079 & $34.4 \mathrm{cdef}$ & $3.7 \mathrm{abc}$ & $66 \mathrm{fgh}$ & $492 \mathrm{abc}$ & $39.4 \mathrm{bcde}$ \\
1207 & $39.1 \mathrm{cdef}$ & $2.0 \mathrm{bc}$ & $72 \mathrm{def}$ & $405 \mathrm{de}$ & $33.1 \mathrm{cdef}$ \\
1214 & $26.1 \mathrm{ef}$ & $1.4 \mathrm{bc}$ & $71 \mathrm{def}$ & $397 \mathrm{de}$ & $34.6 \mathrm{cdef}$ \\
1229 & $25.5 \mathrm{ef}$ & $2.1 \mathrm{abc}$ & $65 \mathrm{fgh}$ & $390 \mathrm{de}$ & $41.4 \mathrm{bcd}$ \\
1245 & $20.9 \mathrm{f}$ & $0.3 \mathrm{c}$ & $68 \mathrm{fgh}$ & $355 \mathrm{e}$ & $38.0 \mathrm{bcdef}$ \\
1267 & $40.2 \mathrm{cdef}$ & $4.0 \mathrm{abc}$ & $65 \mathrm{fgh}$ & $530 \mathrm{a}$ & $37.6 \mathrm{bcdef}$ \\
1448 & $48.4 \mathrm{cdef}$ & $4.0 \mathrm{abc}$ & $81 \mathrm{abc}$ & $411 \mathrm{cde}$ & $68.7 \mathrm{a}$ \\
1588 & $79.8 \mathrm{bcd}$ & $4.9 \mathrm{ab}$ & $76 \mathrm{cde}$ & $406 \mathrm{de}$ & $49.7 \mathrm{bc}$ \\
1760 & $77.6 \mathrm{bcde}$ & $5.9 \mathrm{a}$ & $77 \mathrm{~cd}$ & $432 \mathrm{bcde}$ & $52.7 \mathrm{~b}$ \\
Reubens & $140.2 \mathrm{a}$ & $3.4 \mathrm{abc}$ & $80 \mathrm{bc}$ & $417 \mathrm{cde}$ & $46.0 \mathrm{bc}$ \\
Nugget & $82.0 \mathrm{bc}$ & $3.3 \mathrm{abc}$ & $81 \mathrm{abc}$ & $504 \mathrm{ab}$ & $38.5 \mathrm{bcdef}$ \\
\hline \hline
\end{tabular}

${ }^{\dagger}$ Days from April 15 to maturity.

${ }^{\ddagger}$ Means within columns followed by the same letter are not significantly different by Duncan's new multiple range test $(\mathrm{P} \leq 0.05)$. $\mathrm{n}=5$ for all means. 
Table A.30. Performance of selected alpine bluegrass lines in transplanted provenance trial at Vegreville in 1989. The trial was established in 1987.

\begin{tabular}{rccccc}
\hline \hline Line & $\begin{array}{c}\text { Number of Heads } \\
\left(\text { no. plant }{ }^{-1}\right)\end{array}$ & $\begin{array}{c}\text { Seed Yield } \\
\left(\mathrm{g} \mathrm{plant}^{-1}\right)\end{array}$ & $\begin{array}{c}\text { Time to Maturity } \\
\left(\text { days }{ }^{\dagger}\right)\end{array}$ & $\begin{array}{c}1000 \text { Seed Wt. } \\
(\mathrm{mg})\end{array}$ & $\begin{array}{c}\text { Plant Height } \\
(\mathrm{cm})\end{array}$ \\
\hline 745 & $102.2 \mathrm{bc}^{\ddagger}$ & $3.6 \mathrm{a}$ & $81 \mathrm{bcde}$ & $400 \mathrm{c}$ & $19.7 \mathrm{c}$ \\
752 & $115.9 \mathrm{~b}$ & $2.6 \mathrm{a}$ & $84 \mathrm{bc}$ & $468 \mathrm{bc}$ & $26.8 \mathrm{bc}$ \\
864 & $26.4 \mathrm{~d}$ & $1.5 \mathrm{a}$ & $73 \mathrm{f}$ & $435 \mathrm{c}$ & $26.3 \mathrm{bc}$ \\
907 & $41.9 \mathrm{~cd}$ & $3.2 \mathrm{a}$ & $72 \mathrm{f}$ & $438 \mathrm{c}$ & $29.4 \mathrm{ab}$ \\
1001 & $27.9 \mathrm{~d}$ & $3.1 \mathrm{a}$ & $80 \mathrm{bcde}$ & $526 \mathrm{ab}$ & $28.4 \mathrm{ab}$ \\
1003 & $40.8 \mathrm{~cd}$ & $4.1 \mathrm{a}$ & $78 \mathrm{cdef}$ & $566 \mathrm{a}$ & $30.2 \mathrm{ab}$ \\
1079 & $23.6 \mathrm{~d}$ & $2.7 \mathrm{a}$ & $77 \mathrm{def}$ & $542 \mathrm{ab}$ & $31.8 \mathrm{ab}$ \\
1207 & $38.4 \mathrm{~cd}$ & $1.5 \mathrm{a}$ & $80 \mathrm{bcde}$ & $474 \mathrm{bc}$ & $26.8 \mathrm{bc}$ \\
1214 & $49.6 \mathrm{bcd}$ & $2.3 \mathrm{a}$ & $79 \mathrm{bcde}$ & $432 \mathrm{c}$ & $28.4 \mathrm{ab}$ \\
1229 & $7.7 \mathrm{~d}$ & $0.4 \mathrm{a}$ & $76 \mathrm{ef}$ & $430 \mathrm{c}$ & $23.8 \mathrm{bc}$ \\
1245 & $14.5 \mathrm{~d}$ & $0.4 \mathrm{a}$ & $79 \mathrm{bcde}$ & $413 \mathrm{c}$ & $26.7 \mathrm{bc}$ \\
1267 & $22.2 \mathrm{~d}$ & $2.4 \mathrm{a}$ & $78 \mathrm{cdef}$ & $545 \mathrm{ab}$ & $29.0 \mathrm{ab}$ \\
1448 & $40.1 \mathrm{~cd}$ & $2.2 \mathrm{a}$ & $80 \mathrm{bcde}$ & $428 \mathrm{c}$ & $31.6 \mathrm{ab}$ \\
1588 & $43.6 \mathrm{~cd}$ & $1.9 \mathrm{a}$ & $85 \mathrm{~b}$ & $523 \mathrm{c}$ & $28.8 \mathrm{ab}$ \\
1760 & $34.9 \mathrm{~cd}$ & $1.9 \mathrm{a}$ & $83 \mathrm{bcd}$ & $474 \mathrm{bc}$ & $31.0 \mathrm{ab}$ \\
Reubens & $222.5 \mathrm{a}$ & $5.2 \mathrm{a}$ & $94 \mathrm{a}$ & $433 \mathrm{c}$ & $36.3 \mathrm{a}$ \\
Nugget & $69.9 \mathrm{bcd}$ & $2.1 \mathrm{a}$ & $94 \mathrm{a}$ & $565 \mathrm{a}$ & $25.5 \mathrm{bc}$ \\
\hline \hline
\end{tabular}

${ }^{\dagger}$ Days from April 15 to maturity.

${ }^{\ddagger}$ Means within columns followed by the same letter are not significantly different by Duncan's new multiple range test $(\mathrm{P} \leq 0.05)$. $\mathrm{n}=5$ for all means. 
Table A.31. Performance of selected alpine bluegrass lines in seeded provenance trial 1 at Vegreville in 1988. The trial was established in 1987.

\begin{tabular}{rccccc}
\hline \hline Line & $\begin{array}{c}\text { Number of Heads } \\
\left.(\text { no. m })^{-1}\right)\end{array}$ & $\begin{array}{c}\text { Seed Yield } \\
\left(\mathrm{g} \mathrm{m}^{-1}\right)\end{array}$ & $\begin{array}{c}\text { Above-ground } \\
\text { Biomass } \\
\left(\mathrm{g} \mathrm{m}^{-1}\right)\end{array}$ & $\begin{array}{c}\text { Time to } \\
\text { Maturity } \\
(\text { days })\end{array}$ & $\begin{array}{c}1000 \text { Seed Wt. } \\
(\mathrm{mg})\end{array}$ \\
\hline 745 & $256 \mathrm{abcd} \mathrm{d}^{\ddagger}$ & $4.3 \mathrm{c}$ & $139 \mathrm{f}$ & $82 \mathrm{a}$ & $398 \mathrm{f}$ \\
752 & $417 \mathrm{ab}$ & $5.1 \mathrm{c}$ & $181 \mathrm{f}$ & $84 \mathrm{a}$ & $401 \mathrm{f}$ \\
864 & $217 \mathrm{~cd}$ & $11.0 \mathrm{abc}$ & $196 \mathrm{ef}$ & $60 \mathrm{~d}$ & $419 \mathrm{ef}$ \\
907 & $230 \mathrm{bcd}$ & $10.2 \mathrm{abc}$ & $215 \mathrm{ef}$ & $60 \mathrm{~d}$ & $428 \mathrm{def}$ \\
1001 & $189 \mathrm{~cd}$ & $19.7 \mathrm{ab}$ & $240 \mathrm{ef}$ & $63 \mathrm{~cd}$ & $501 \mathrm{bc}$ \\
1003 & $203 \mathrm{~cd}$ & $19.9 \mathrm{ab}$ & $297 \mathrm{bcde}$ & $63 \mathrm{~cd}$ & $485 \mathrm{bcd}$ \\
1079 & $182 \mathrm{~d}$ & $20.0 \mathrm{ab}$ & $278 \mathrm{cdef}$ & $61 \mathrm{~d}$ & $528 \mathrm{ab}$ \\
1207 & $213 \mathrm{~cd}$ & $12.0 \mathrm{abc}$ & $186 \mathrm{ef}$ & $66 \mathrm{c}$ & $405 \mathrm{f}$ \\
1214 & $198 \mathrm{~cd}$ & $12.3 \mathrm{abc}$ & $200 \mathrm{ef}$ & $64 \mathrm{~cd}$ & $429 \mathrm{def}$ \\
1229 & $153 \mathrm{~d}$ & $11.3 \mathrm{abc}$ & $219 \mathrm{ef}$ & $60 \mathrm{~d}$ & $424 \mathrm{ef}$ \\
1245 & $155 \mathrm{~d}$ & $7.5 \mathrm{bc}$ & $269 \mathrm{def}$ & $62 \mathrm{~cd}$ & $427 \mathrm{def}$ \\
1267 & $119 \mathrm{~d}$ & $13.5 \mathrm{abc}$ & $256 \mathrm{ef}$ & $62 \mathrm{~cd}$ & $496 \mathrm{bc}$ \\
1448 & $368 \mathrm{abc}$ & $23.3 \mathrm{a}$ & $394 \mathrm{bcd}$ & $71 \mathrm{~b}$ & $467 \mathrm{cde}$ \\
1588 & $425 \mathrm{a}$ & $19.5 \mathrm{ab}$ & $418 \mathrm{~b}$ & $73 \mathrm{~b}$ & $428 \mathrm{def}$ \\
1760 & $445 \mathrm{a}$ & $23.7 \mathrm{a}$ & $410 \mathrm{bc}$ & $73 \mathrm{~b}$ & $429 \mathrm{def}$ \\
Reubens & - & - & $565 \mathrm{a}$ & $80 \mathrm{a}$ & - \\
Nugget & $269 \mathrm{abcd}$ & $8.3 \mathrm{bc}$ & $408 \mathrm{bc}$ & $84 \mathrm{a}$ & $575 \mathrm{a}$ \\
\hline \hline
\end{tabular}

${ }^{\dagger}$ Days from April 15 to maturity.

${ }^{\ddagger}$ Means within columns followed by the same letter are not significantly different by Duncan's new multiple range test $(\mathrm{P} \leq 0.05)$. $\mathrm{n}=4$ for all means. 
Table A.32. Performance of selected alpine bluegrass lines in seeded provenance trial 1 at Vegreville in 1989. The trial was established in 1987.

\begin{tabular}{rccccc}
\hline \hline Line & $\begin{array}{c}\text { Number of Heads } \\
\left(\text { no. } \mathrm{m}^{-1}\right)\end{array}$ & $\begin{array}{c}\text { Seed Yield } \\
\left(\mathrm{g} \mathrm{m}^{-1}\right)\end{array}$ & $\begin{array}{c}\text { Time to Maturity } \\
\left(\text { days }^{\dagger}\right)\end{array}$ & $\begin{array}{c}1000 \text { Seed Wt. } \\
(\mathrm{mg})\end{array}$ & $\begin{array}{c}\text { Plant Height } \\
(\mathrm{cm})\end{array}$ \\
\hline 745 & - & - & - & - & $13.0 \mathrm{c}$ \\
752 & $32 \mathrm{~d}^{\ddagger}$ & $0.5 \mathrm{e}$ & $85 \mathrm{~b}$ & $350 \mathrm{~g}$ & $29.5 \mathrm{~b}$ \\
864 & $54 \mathrm{~d}$ & $3.0 \mathrm{de}$ & $69 \mathrm{~cd}$ & $408 \mathrm{efg}$ & $30.5 \mathrm{ab}$ \\
907 & $97 \mathrm{~d}$ & $7.3 \mathrm{cde}$ & $68 \mathrm{~d}$ & $463 \mathrm{cdef}$ & $36.0 \mathrm{ab}$ \\
1001 & $77 \mathrm{~d}$ & $6.7 \mathrm{cde}$ & $74 \mathrm{~cd}$ & $563 \mathrm{ab}$ & $34.3 \mathrm{ab}$ \\
1003 & $104 \mathrm{~d}$ & $10.4 \mathrm{c}$ & $74 \mathrm{~cd}$ & $583 \mathrm{a}$ & $38.3 \mathrm{a}$ \\
1079 & $37 \mathrm{~d}$ & $3.6 \mathrm{de}$ & $71 \mathrm{~cd}$ & $528 \mathrm{abc}$ & $33.3 \mathrm{ab}$ \\
1207 & $251 \mathrm{c}$ & $8.2 \mathrm{~cd}$ & $74 \mathrm{~cd}$ & $442 \mathrm{def}$ & $32.8 \mathrm{ab}$ \\
1214 & $152 \mathrm{c}$ & $6.0 \mathrm{cde}$ & $75 \mathrm{c}$ & $452 \mathrm{cdef}$ & $32.3 \mathrm{ab}$ \\
1229 & $108 \mathrm{~d}$ & $7.4 \mathrm{cde}$ & $73 \mathrm{~cd}$ & $492 \mathrm{bcd}$ & $36.8 \mathrm{ab}$ \\
1245 & $63 \mathrm{~d}$ & $3.4 \mathrm{de}$ & $74 \mathrm{~cd}$ & $477 \mathrm{cde}$ & $35.8 \mathrm{ab}$ \\
1267 & $37 \mathrm{~d}$ & $5.3 \mathrm{cde}$ & $73 \mathrm{~cd}$ & $565 \mathrm{ab}$ & $35.0 \mathrm{ab}$ \\
1448 & $37 \mathrm{~d}$ & $2.5 \mathrm{de}$ & $75 \mathrm{c}$ & $450 \mathrm{def}$ & $36.0 \mathrm{ab}$ \\
1588 & $75 \mathrm{~d}$ & $5.3 \mathrm{cde}$ & $75 \mathrm{c}$ & $482 \mathrm{cde}$ & $36.0 \mathrm{ab}$ \\
1760 & $76 \mathrm{~d}$ & $6.3 \mathrm{cde}$ & $75 \mathrm{c}$ & $505 \mathrm{bcd}$ & $38.0 \mathrm{a}$ \\
Reubens & $1096 \mathrm{a}$ & $36.3 \mathrm{a}$ & $96 \mathrm{a}$ & $390 \mathrm{fg}$ & $35.0 \mathrm{ab}$ \\
Nugget & $528 \mathrm{~b}$ & $18.9 \mathrm{~b}$ & $89 \mathrm{~b}$ & $595 \mathrm{a}$ & $35.8 \mathrm{ab}$ \\
\hline \hline
\end{tabular}

${ }^{\dagger}$ Days from April 15 to maturity.

${ }^{\ddagger}$ Means within columns followed by the same letter are not significantly different by Duncan's new multiple range test $(P \leq 0.05)$. $n=4$ for all means. 
Table A.33. Performance of selected alpine bluegrass lines in seeded provenance trial 2 at Vegreville in 1990. The trial was established in 1989.

\begin{tabular}{rccccc}
\hline \hline Line & $\begin{array}{c}\text { Number of Heads } \\
\left(\text { no. } \mathrm{m}^{-1}\right)\end{array}$ & $\begin{array}{c}\text { Seed Yield } \\
\left(\mathrm{g} \mathrm{m}^{-1}\right)\end{array}$ & $\begin{array}{c}\text { Time to Maturity } \\
\left(\text { days }^{\dagger}\right)\end{array}$ & $\begin{array}{c}\text { Plant Height } \\
(\mathrm{cm})\end{array}$ & $\begin{array}{c}\text { Flag Leaf } \\
\text { Length } \\
(\mathrm{cm})\end{array}$ \\
\hline 745 & $557 \mathrm{a}^{\ddagger}$ & $36.9 \mathrm{a}$ & $87 \mathrm{~b}$ & $30.0 \mathrm{ab}$ & $6.1 \mathrm{ab}$ \\
752 & $15 \mathrm{c}$ & $0.3 \mathrm{~b}$ & $87 \mathrm{~b}$ & $18.1 \mathrm{f}$ & $3.6 \mathrm{de}$ \\
864 & $108 \mathrm{c}$ & $11.5 \mathrm{~b}$ & $64 \mathrm{f}$ & $27.6 \mathrm{bcd}$ & $4.2 \mathrm{bcde}$ \\
907 & $13 \mathrm{c}$ & $0.4 \mathrm{~b}$ & $81 \mathrm{bcd}$ & $19.7 \mathrm{def}$ & $4.2 \mathrm{bcde}$ \\
1001 & $23 \mathrm{c}$ & $0.2 \mathrm{~b}$ & $84 \mathrm{bc}$ & $19.2 \mathrm{ef}$ & $4.1 \mathrm{cde}$ \\
1003 & $11 \mathrm{c}$ & $0.7 \mathrm{~b}$ & $80 \mathrm{bcd}$ & $20.5 \mathrm{def}$ & $4.4 \mathrm{bcde}$ \\
1079 & $2 \mathrm{c}$ & $0.1 \mathrm{~b}$ & $80 \mathrm{bcd}$ & $18.3 \mathrm{f}$ & $3.6 \mathrm{e}$ \\
1207 & $81 \mathrm{c}$ & $7.0 \mathrm{~b}$ & $74 \mathrm{de}$ & $21.2 \mathrm{cdef}$ & $3.5 \mathrm{e}$ \\
1214 & $78 \mathrm{c}$ & $3.6 \mathrm{~b}$ & $72 \mathrm{e}$ & $22.1 \mathrm{cdef}$ & $4.3 \mathrm{bcde}$ \\
1229 & $8 \mathrm{c}$ & $0.2 \mathrm{~b}$ & $83 \mathrm{bc}$ & $23.1 \mathrm{bcdef}$ & $5.1 \mathrm{abcde}$ \\
1245 & $56 \mathrm{c}$ & $4.3 \mathrm{~b}$ & $83 \mathrm{bc}$ & $22.0 \mathrm{cdef}$ & $3.4 \mathrm{e}$ \\
1267 & $3 \mathrm{c}$ & $0.2 \mathrm{~b}$ & $80 \mathrm{bcd}$ & $20.3 \mathrm{def}$ & $6.0 \mathrm{ab}$ \\
1448 & $163 \mathrm{bc}$ & $9.3 \mathrm{~b}$ & $80 \mathrm{bcd}$ & $29.0 \mathrm{bc}$ & $5.7 \mathrm{abc}$ \\
1588 & $103 \mathrm{c}$ & $5.4 \mathrm{~b}$ & $78 \mathrm{cde}$ & $25.8 \mathrm{bcdef}$ & $5.5 \mathrm{abcd}$ \\
1760 & $126 \mathrm{c}$ & $10.6 \mathrm{~b}$ & $76 \mathrm{cde}$ & $27.0 \mathrm{bcde}$ & $4.8 \mathrm{bcde}$ \\
Reubens & $312 \mathrm{~b}$ & $2.9 \mathrm{~b}$ & $96 \mathrm{a}$ & $36.4 \mathrm{a}$ & $5.3 \mathrm{abcde}$ \\
Nugget & $667 \mathrm{a}$ & $27.6 \mathrm{a}$ & $88 \mathrm{~b}$ & $21.3 \mathrm{cdef}$ & $6.9 \mathrm{a}$ \\
\hline \hline
\end{tabular}

${ }^{\dagger}$ Days from April 15 to maturity.

${ }^{\ddagger}$ Means within columns followed by the same letter are not significantly different by Duncan’s new multiple range test $(\mathrm{P} \leq 0.05)$. $\mathrm{n}=4$ for all means. 
Table A.34. Performance of selected alpine bluegrass lines in seeded provenance trial 2 at Vegreville in 1990. The trial was established in 1989.

\begin{tabular}{rcccccc}
\hline \hline Line & $\begin{array}{c}\text { Number of Heads } \\
\left(\text { no. } \mathrm{m}^{-1}\right)\end{array}$ & $\begin{array}{c}\text { Seed Yield } \\
\left(\mathrm{g} \mathrm{m}^{-1}\right)\end{array}$ & $\begin{array}{c}\text { Time to } \\
\text { Maturity } \\
\left(\text { days }^{\dagger}\right)\end{array}$ & $\begin{array}{c}1000 \text { Seed Wt. Plant Height } \\
(\mathrm{mg})\end{array}$ & $\begin{array}{c}\text { Flag Leaf } \\
(\mathrm{cm})\end{array}$ & $\begin{array}{c}\text { Length } \\
(\mathrm{cm})\end{array}$ \\
\hline 745 & - & - & - & - & - & - \\
752 & - & - & - & - & - \\
864 & $62 \mathrm{~b}^{\ddagger}$ & $2.2 \mathrm{~b}$ & $72 \mathrm{~g}$ & $321 \mathrm{c}$ & $30.9 \mathrm{~b}$ & $3.4 \mathrm{ef}$ \\
907 & $40 \mathrm{~b}$ & $2.0 \mathrm{~b}$ & $74 \mathrm{fg}$ & $452 \mathrm{ab}$ & $29.3 \mathrm{~b}$ & $3.7 \mathrm{ef}$ \\
1001 & $21 \mathrm{~b}$ & $1.8 \mathrm{~b}$ & $84 \mathrm{c}$ & $454 \mathrm{ab}$ & $31.0 \mathrm{~b}$ & $4.0 \mathrm{def}$ \\
1003 & $24 \mathrm{~b}$ & $2.1 \mathrm{~b}$ & $76 \mathrm{ef}$ & $446 \mathrm{ab}$ & $29.5 \mathrm{~b}$ & $5.2 \mathrm{bcd}$ \\
1079 & $7 \mathrm{~b}$ & $0.3 \mathrm{~b}$ & $77 \mathrm{ef}$ & $437 \mathrm{ab}$ & $30.5 \mathrm{~b}$ & $6.3 \mathrm{ab}$ \\
1207 & $81 \mathrm{~b}$ & $4.1 \mathrm{~b}$ & $75 \mathrm{fg}$ & $356 \mathrm{c}$ & $32.9 \mathrm{~b}$ & $3.1 \mathrm{f}$ \\
1214 & $116 \mathrm{~b}$ & $6.0 \mathrm{~b}$ & $74 \mathrm{fg}$ & $352 \mathrm{c}$ & $32.8 \mathrm{~b}$ & $3.1 \mathrm{f}$ \\
1229 & $29 \mathrm{~b}$ & $1.1 \mathrm{~b}$ & $77 \mathrm{ef}$ & $379 \mathrm{bc}$ & $34.7 \mathrm{~b}$ & $4.2 \mathrm{cdef}$ \\
1245 & $51 \mathrm{~b}$ & $2.3 \mathrm{~b}$ & $77 \mathrm{ef}$ & $357 \mathrm{c}$ & $30.8 \mathrm{~b}$ & $3.6 \mathrm{ef}$ \\
1267 & $22 \mathrm{~b}$ & $0.8 \mathrm{~b}$ & $84 \mathrm{c}$ & $322 \mathrm{c}$ & $29.7 \mathrm{~b}$ & $6.8 \mathrm{a}$ \\
1448 & $90 \mathrm{~b}$ & $5.1 \mathrm{~b}$ & $80 \mathrm{de}$ & $354 \mathrm{c}$ & $31.6 \mathrm{~b}$ & $5.3 \mathrm{bc}$ \\
1588 & $71 \mathrm{~b}$ & $3.0 \mathrm{~b}$ & $81 \mathrm{~cd}$ & $350 \mathrm{c}$ & $31.3 \mathrm{~b}$ & $4.9 \mathrm{~cd}$ \\
1760 & $119 \mathrm{~b}$ & $6.8 \mathrm{~b}$ & $80 \mathrm{de}$ & $353 \mathrm{c}$ & $30.5 \mathrm{~b}$ & $5.3 \mathrm{bc}$ \\
Reubens & $979 \mathrm{a}$ & $15.7 \mathrm{a}$ & $98 \mathrm{a}$ & $250 \mathrm{~d}$ & $46.4 \mathrm{a}$ & $5.4 \mathrm{bc}$ \\
Nugget & $107 \mathrm{~b}$ & $4.6 \mathrm{~b}$ & $88 \mathrm{~b}$ & $503 \mathrm{a}$ & $28.9 \mathrm{~b}$ & $4.4 \mathrm{cde}$ \\
\hline \hline
\end{tabular}

${ }^{\dagger}$ Days from April 15 to maturity.

${ }^{\ddagger}$ Means within columns followed by the same letter are not significantly different by Duncan's new multiple range test $(\mathrm{P} \leq 0.05)$. $\mathrm{n}=4$ for all means. 

APPENDIX B

PERFORMANCE OF ALPINE BLUEGRASS

LINES IN INDIVIDUAL MULTILOCATION TRIALS 
Table B.1. Performance of selected alpine bluegrass lines in multilocation trial 1 at Columbia Icefields in 1991. The trial was seeded in 1990.

\begin{tabular}{lcc}
\hline \hline Line & $\begin{array}{c}\text { Emergence } \\
\left(\text { no. } p l a n t s ~ ~^{-1}\right)\end{array}$ & $\begin{array}{c}\text { Cover } \\
(\%)\end{array}$ \\
\hline M1 $(1448+1588+1760)$ & $121 \mathrm{a}^{\dagger}$ & $48.3 \mathrm{a}$ \\
M2 $(907+1003+1214)$ & $80 \mathrm{a}$ & $36.7 \mathrm{ab}$ \\
M3 $(864+907+1079+1229)$ & $61 \mathrm{a}$ & $24.2 \mathrm{bc}$ \\
907 & $86 \mathrm{a}$ & $35.0 \mathrm{ab}$ \\
1003 & $98 \mathrm{a}$ & $43.3 \mathrm{ab}$ \\
1448 & $86 \mathrm{a}$ & $41.7 \mathrm{ab}$ \\
1588 & $95 \mathrm{a}$ & $39.2 \mathrm{ab}$ \\
1760 & $110 \mathrm{a}$ & $47.5 \mathrm{ab}$ \\
Reubens & $105 \mathrm{a}$ & $27.5 \mathrm{abc}$ \\
Nugget & $73 \mathrm{a}$ & $8.3 \mathrm{c}$ \\
\hline \hline
\end{tabular}

${ }^{\dagger}$ Means within columns followed by the same letter are not significantly different by Duncan's new multiple range test $(P \leq 0.05)$. $n=6$ for all means. 
Table B.2. Performance of selected alpine bluegrass lines in multilocation trial 1 at Columbia Icefields in 1992. The trial was seeded in 1990.

\begin{tabular}{lccccc}
\hline \hline Line & $\begin{array}{c}\text { Cover } \\
(\%)\end{array}$ & $\begin{array}{c}\text { Number of Heads } \\
\left(\text { no. } \mathrm{m}^{-1}\right)\end{array}$ & $\begin{array}{c}\text { Seed Yield } \\
\left(\mathrm{mg} \mathrm{m}^{-1}\right)\end{array}$ & $\begin{array}{c}\text { Plant Height } \\
(\mathrm{cm})\end{array}$ & $\begin{array}{c}\text { Plant Width } \\
(\mathrm{cm})\end{array}$ \\
\hline M1 $(1448+1588+1760)$ & $77.5 \mathrm{a}^{\dagger}$ & $0.8 \mathrm{a}$ & $2.8 \mathrm{a}$ & $21.5 \mathrm{ab}$ & $3.2 \mathrm{a}$ \\
M2 $(907+1003+1214)$ & $70.0 \mathrm{a}$ & $0.4 \mathrm{a}$ & $5.4 \mathrm{a}$ & $18.2 \mathrm{bc}$ & $3.7 \mathrm{a}$ \\
M3 $(864+907+1079+1229)$ & $79.2 \mathrm{a}$ & $1.1 \mathrm{a}$ & $9.4 \mathrm{a}$ & $16.5 \mathrm{c}$ & $3.2 \mathrm{a}$ \\
907 & $63.3 \mathrm{a}$ & $1.4 \mathrm{a}$ & $17.1 \mathrm{a}$ & $16.0 \mathrm{c}$ & $2.7 \mathrm{a}$ \\
1003 & $84.2 \mathrm{a}$ & $0.6 \mathrm{a}$ & $5.9 \mathrm{a}$ & $20.0 \mathrm{abc}$ & $3.3 \mathrm{a}$ \\
1448 & $74.2 \mathrm{a}$ & $1.2 \mathrm{a}$ & $12.9 \mathrm{a}$ & $23.3 \mathrm{a}$ & $3.7 \mathrm{a}$ \\
1588 & $70.0 \mathrm{a}$ & $1.1 \mathrm{a}$ & $8.7 \mathrm{a}$ & $21.8 \mathrm{ab}$ & $3.5 \mathrm{a}$ \\
1760 & $81.7 \mathrm{a}$ & $0.6 \mathrm{a}$ & $4.6 \mathrm{a}$ & $21.0 \mathrm{ab}$ & $3.2 \mathrm{a}$ \\
Reubens & $60.8 \mathrm{a}$ & $0.7 \mathrm{a}$ & $1.2 \mathrm{a}$ & $21.0 \mathrm{ab}$ & $4.0 \mathrm{a}$ \\
Nugget & $14.2 \mathrm{~b}$ & $0.0 \mathrm{a}$ & $0.0 \mathrm{a}$ & - & $2.7 \mathrm{a}$ \\
\hline \hline
\end{tabular}

${ }^{\dagger}$ Means within columns followed by the same letter are not significantly different by Duncan's new multiple range test $(\mathrm{P} \leq 0.05)$. $\mathrm{n}=6$ for all means. 
Table B.3. Performance of selected alpine bluegrass lines in multilocation trial 1 at Columbia Icefields in 1993. The trial was seeded in 1990.

\begin{tabular}{lcc}
\hline \hline Line & $\begin{array}{c}\text { Cover } \\
(\%)\end{array}$ & $\begin{array}{c}\text { Number of Heads } \\
\left(\text { no. } \mathrm{m}^{-1}\right)\end{array}$ \\
\hline M1 $(1448+1588+1760)$ & $11.7 \mathrm{a}^{\dagger}$ & - \\
M2 $(907+1003+1214)$ & $20.8 \mathrm{a}$ & $0.8 \mathrm{a}$ \\
M3 $(864+907+1079+1229)$ & $10.8 \mathrm{a}$ & $0.7 \mathrm{a}$ \\
907 & $13.3 \mathrm{a}$ & $0.5 \mathrm{a}$ \\
1003 & $17.5 \mathrm{a}$ & - \\
1448 & $12.5 \mathrm{a}$ & $0.5 \mathrm{a}$ \\
1588 & $15.0 \mathrm{a}$ & $0.8 \mathrm{a}$ \\
1760 & $17.5 \mathrm{a}$ & - \\
Reubens & $14.2 \mathrm{a}$ & - \\
Nugget & $2.8 \mathrm{a}$ & - \\
\hline \hline
\end{tabular}

${ }^{\dagger}$ Means within columns followed by the same letter are not significantly different by Duncan's new multiple range test $(P \leq 0.05)$. $n=6$ for all means. 
Table B.4. Performance of selected alpine bluegrass lines in multilocation trial 1 at Columbia Icefields in 1994. The trial was seeded in 1990.

\begin{tabular}{lccccc}
\hline \hline Line & $\begin{array}{c}\text { Cover } \\
(\%)\end{array}$ & $\begin{array}{c}\text { Number of Heads } \\
\left(\text { no. } \mathrm{m}^{-1}\right)\end{array}$ & $\begin{array}{c}\text { Seed Yield } \\
\left(\mathrm{mg} \mathrm{m}^{-1}\right)\end{array}$ & $\begin{array}{c}\text { Plant Height } \\
(\mathrm{cm})\end{array}$ & $\begin{array}{c}\text { Plant Width } \\
(\mathrm{cm})\end{array}$ \\
\hline M1 $(1448+1588+1760)$ & $48.3 \mathrm{ab}^{\dagger}$ & $0.0 \mathrm{a}$ & $0.0 \mathrm{a}$ & - & $6.2 \mathrm{a}$ \\
M2 $(907+1003+1214)$ & $68.3 \mathrm{a}$ & $0.8 \mathrm{a}$ & $10.5 \mathrm{a}$ & $17.0 \mathrm{a}$ & $3.7 \mathrm{~b}$ \\
M3 $(864+907+1079+1229)$ & $34.2 \mathrm{~b}$ & $0.6 \mathrm{a}$ & $17.7 \mathrm{a}$ & $22.0 \mathrm{a}$ & $3.8 \mathrm{~b}$ \\
907 & $38.3 \mathrm{ab}$ & $0.3 \mathrm{a}$ & $6.7 \mathrm{a}$ & $16.5 \mathrm{a}$ & $3.2 \mathrm{~b}$ \\
1003 & $53.3 \mathrm{ab}$ & $0.0 \mathrm{a}$ & $0.0 \mathrm{a}$ & - & $3.3 \mathrm{~b}$ \\
1448 & $43.3 \mathrm{ab}$ & $0.3 \mathrm{a}$ & $6.3 \mathrm{a}$ & $23.0 \mathrm{a}$ & $5.3 \mathrm{ab}$ \\
1588 & $51.7 \mathrm{ab}$ & $0.7 \mathrm{a}$ & $10.7 \mathrm{a}$ & $21.7 \mathrm{a}$ & $6.7 \mathrm{a}$ \\
1760 & $45.0 \mathrm{ab}$ & $0.2 \mathrm{a}$ & $4.3 \mathrm{a}$ & $20.0 \mathrm{a}$ & $6.3 \mathrm{a}$ \\
Reubens & $20.8 \mathrm{bc}$ & $0.1 \mathrm{a}$ & $0.5 \mathrm{a}$ & $17.0 \mathrm{a}$ & $5.2 \mathrm{ab}$ \\
Nugget & $4.2 \mathrm{c}$ & $0.0 \mathrm{a}$ & $0.0 \mathrm{a}$ & - & $3.3 \mathrm{~b}$ \\
\hline \hline
\end{tabular}

${ }^{\dagger}$ Means within columns followed by the same letter are not significantly different by Duncan's new multiple range test $(P \leq 0.05), n=6$ for all means. 
Table B.5. Performance of selected alpine bluegrass lines in multilocation trial 2 at Columbia Icefields in 1991, 1992 \& 1993. The trial was seeded in 1991.

\begin{tabular}{lccc}
\hline \hline & & \multicolumn{2}{c}{ Cover (\%) } \\
\cline { 3 - 4 } Line & $\begin{array}{c}\text { Emergence } \\
\left(\text { no. plants } \mathrm{m}^{-1}\right)\end{array}$ & 1992 & 1993 \\
\hline M1 $(1448+1588+1760)$ & $29 \mathrm{a}^{\dagger}$ & $31.7 \mathrm{abc}$ & $1.0 \mathrm{a}$ \\
M2 $(907+1003+1214)$ & $21 \mathrm{a}$ & $19.2 \mathrm{bc}$ & $1.3 \mathrm{a}$ \\
M3 $(864+907+1079+1229)$ & $35 \mathrm{a}$ & $52.5 \mathrm{a}$ & $0.5 \mathrm{a}$ \\
907 & $34 \mathrm{a}$ & $48.3 \mathrm{a}$ & $0.5 \mathrm{a}$ \\
1003 & $45 \mathrm{a}$ & $45.0 \mathrm{ab}$ & $1.0 \mathrm{a}$ \\
1448 & $34 \mathrm{a}$ & $40.0 \mathrm{abc}$ & $4.5 \mathrm{a}$ \\
1588 & $27 \mathrm{a}$ & $40.0 \mathrm{abc}$ & $1.0 \mathrm{a}$ \\
1760 & $42 \mathrm{a}$ & $46.7 \mathrm{a}$ & $1.2 \mathrm{a}$ \\
Reubens & $30 \mathrm{a}$ & $15.0 \mathrm{c}$ & $0.2 \mathrm{a}$ \\
Nugget & $27 \mathrm{a}$ & $14.2 \mathrm{c}$ & $0.2 \mathrm{a}$ \\
\hline \hline
\end{tabular}

${ }^{\dagger}$ Means within columns followed by the same letter are not significantly different by Duncan's new multiple range test $(P \leq 0.05) . n=6$ for all means. 
Table B.6. Performance of selected alpine bluegrass lines in multilocation trial 1 at Mountain Park in 1991. The trial was seeded in 1990.

\begin{tabular}{lccc}
\hline \hline Line & $\begin{array}{c}\text { Emergence } \\
\left(\text { no. plants } \mathrm{m}^{-1}\right)\end{array}$ & $\begin{array}{c}\text { Cover } \\
(\%)\end{array}$ & $\begin{array}{c}\text { Number of Heads } \\
\left(\text { no. } \mathrm{m}^{-1}\right)\end{array}$ \\
\hline M1 (1448+1588+1760) & $35 \mathrm{bcd}^{\dagger}$ & $33.3 \mathrm{a}$ & $0.1 \mathrm{~b}$ \\
M2 $(907+1003+1214)$ & $37 \mathrm{abcd}$ & $24.2 \mathrm{ab}$ & $0.0 \mathrm{~b}$ \\
M3 $(864+907+1079+1229)$ & $24 \mathrm{~cd}$ & $9.2 \mathrm{c}$ & $0.0 \mathrm{~b}$ \\
907 & $25 \mathrm{bcd}$ & $13.3 \mathrm{bc}$ & $0.0 \mathrm{~b}$ \\
1003 & $60 \mathrm{a}$ & $30.8 \mathrm{a}$ & $0.0 \mathrm{~b}$ \\
1448 & $38 \mathrm{abcd}$ & $30.0 \mathrm{a}$ & $0.0 \mathrm{~b}$ \\
1588 & $35 \mathrm{bcd}$ & $28.3 \mathrm{a}$ & $0.0 \mathrm{~b}$ \\
1760 & $49 \mathrm{ab}$ & $33.3 \mathrm{a}$ & $0.0 \mathrm{~b}$ \\
Reubens & $41 \mathrm{abc}$ & $28.7 \mathrm{a}$ & $3.5 \mathrm{a}$ \\
Nugget & $15 \mathrm{~d}$ & $11.2 \mathrm{bc}$ & $0.0 \mathrm{~b}$ \\
\hline \hline
\end{tabular}

${ }^{\dagger}$ Means within columns followed by the same letter are not significantly different by Duncan's new multiple range test $(\mathrm{P} \leq 0.05)$. $\mathrm{n}=6$ for all means. 
Table B.7. Performance of selected alpine bluegrass lines in multilocation trial 1 at Mountain Park in 1992. The trial was seeded in 1990.

\begin{tabular}{lccccc}
\hline \hline Line & $\begin{array}{c}\text { Cover } \\
(\%)\end{array}$ & $\begin{array}{c}\text { Number of Heads } \\
\left(\text { no. }^{-1}\right)\end{array}$ & $\begin{array}{c}\text { Seed Yield } \\
\left(\mathrm{mg} \mathrm{m}^{-1}\right)\end{array}$ & $\begin{array}{c}\text { Plant Height } \\
(\mathrm{cm})\end{array}$ & $\begin{array}{c}\text { Plant Width } \\
(\mathrm{cm})\end{array}$ \\
\hline M1 $(1448+1588+1760)$ & $15.8 \mathrm{ab}^{\dagger}$ & $1.2 \mathrm{~b}$ & $7.0 \mathrm{a}$ & $21.2 \mathrm{a}$ & $3.8 \mathrm{a}$ \\
M2 $(907+1003+1214)$ & $15.0 \mathrm{abc}$ & $1.1 \mathrm{~b}$ & $10.0 \mathrm{a}$ & $18.5 \mathrm{a}$ & $2.8 \mathrm{a}$ \\
M3 $(864+907+1079+1229)$ & $9.3 \mathrm{~cd}$ & $1.1 \mathrm{~b}$ & $9.4 \mathrm{a}$ & $17.5 \mathrm{a}$ & $2.7 \mathrm{a}$ \\
907 & $10.3 \mathrm{bcd}$ & $1.1 \mathrm{~b}$ & $9.3 \mathrm{a}$ & $16.0 \mathrm{a}$ & $2.5 \mathrm{a}$ \\
1003 & $18.3 \mathrm{a}$ & $0.6 \mathrm{~b}$ & $10.8 \mathrm{a}$ & $19.3 \mathrm{a}$ & $2.7 \mathrm{a}$ \\
1448 & $16.7 \mathrm{ab}$ & $2.3 \mathrm{~b}$ & $30.2 \mathrm{a}$ & $21.5 \mathrm{a}$ & $4.0 \mathrm{a}$ \\
1588 & $20.0 \mathrm{a}$ & $2.8 \mathrm{~b}$ & $30.0 \mathrm{a}$ & $16.8 \mathrm{a}$ & $3.5 \mathrm{a}$ \\
1760 & $20.0 \mathrm{a}$ & $2.4 \mathrm{~b}$ & $34.3 \mathrm{a}$ & $20.8 \mathrm{a}$ & $3.0 \mathrm{a}$ \\
Reubens & $18.3 \mathrm{a}$ & $5.6 \mathrm{a}$ & $12.3 \mathrm{a}$ & $23.8 \mathrm{a}$ & $4.0 \mathrm{a}$ \\
Nugget & $6.7 \mathrm{~d}$ & $0.2 \mathrm{~b}$ & $5.6 \mathrm{a}$ & - & $3.3 \mathrm{a}$ \\
\hline \hline
\end{tabular}

${ }^{\dagger}$ Means within columns followed by the same letter are not significantly different by Duncan's new multiple range test $(P \leq 0.05), n=6$ for all means. 
Table B.8. Performance of selected alpine bluegrass lines in multilocation trial 1 at Mountain Park in 1993. The trial was seeded in 1990.

\begin{tabular}{lccccc}
\hline \hline Line & $\begin{array}{c}\text { Cover } \\
(\%)\end{array}$ & $\begin{array}{c}\text { Number of Heads } \\
\left(\text { no. } \mathrm{m}^{-1}\right)\end{array}$ & $\begin{array}{c}\text { Seed Yield } \\
\left(\mathrm{mg} \mathrm{m}^{-1}\right)\end{array}$ & $\begin{array}{c}\text { Plant Height } \\
(\mathrm{cm})\end{array}$ & $\begin{array}{c}\text { Plant Width } \\
(\mathrm{cm})\end{array}$ \\
\hline M1 $(1448+1588+1760)$ & $19.2 \mathrm{bc}^{\dagger}$ & $2.3 \mathrm{a}$ & $22.3 \mathrm{abc}$ & $19.8 \mathrm{a}$ & $3.5 \mathrm{a}$ \\
M2 $(907+1003+1214)$ & $25.0 \mathrm{ab}$ & $3.0 \mathrm{a}$ & $19.1 \mathrm{abc}$ & $18.7 \mathrm{a}$ & $2.8 \mathrm{a}$ \\
M3 $(864+907+1079+1229)$ & $15.0 \mathrm{c}$ & $1.5 \mathrm{a}$ & $11.9 \mathrm{bc}$ & $17.0 \mathrm{a}$ & $3.8 \mathrm{a}$ \\
907 & $15.8 \mathrm{c}$ & $2.8 \mathrm{a}$ & $41.1 \mathrm{a}$ & $16.8 \mathrm{a}$ & $4.7 \mathrm{a}$ \\
1003 & $24.2 \mathrm{ab}$ & $0.4 \mathrm{a}$ & $3.7 \mathrm{c}$ & $15.3 \mathrm{a}$ & $3.3 \mathrm{a}$ \\
1448 & $26.7 \mathrm{ab}$ & $2.5 \mathrm{a}$ & $22.8 \mathrm{abc}$ & $20.4 \mathrm{a}$ & $4.5 \mathrm{a}$ \\
1588 & $25.8 \mathrm{ab}$ & $2.2 \mathrm{a}$ & $13.9 \mathrm{bc}$ & $18.4 \mathrm{a}$ & $4.0 \mathrm{a}$ \\
1760 & $32.5 \mathrm{a}$ & $4.1 \mathrm{a}$ & $33.8 \mathrm{ab}$ & $19.3 \mathrm{a}$ & $4.0 \mathrm{a}$ \\
Reubens & $27.5 \mathrm{ab}$ & $3.2 \mathrm{a}$ & $0.0 \mathrm{c}$ & $19.6 \mathrm{a}$ & $4.8 \mathrm{a}$ \\
Nugget & $12.0 \mathrm{c}$ & $0.5 \mathrm{a}$ & $0.0 \mathrm{c}$ & $14.5 \mathrm{a}$ & $2.8 \mathrm{a}$ \\
\hline \hline
\end{tabular}

${ }^{\dagger}$ Means within columns followed by the same letter are not significantly different by Duncan's new multiple range test $(\mathrm{P} \leq 0.05)$. $\mathrm{n}=6$ for all means. 
Table B.9. Performance of selected alpine bluegrass lines in multilocation trial 1 at Mountain Park in 1994. The trial was seeded in 1990.

\begin{tabular}{llcccc}
\hline \hline Line & $\begin{array}{c}\text { Cover } \\
(\%)\end{array}$ & $\begin{array}{c}\text { Number of Heads } \\
\left(\text { no. } \mathrm{m}^{-1}\right)\end{array}$ & $\begin{array}{c}\text { Seed Yield } \\
\left(\mathrm{mg} \mathrm{m}^{-1}\right)\end{array}$ & $\begin{array}{c}\text { Plant Height Plant Width } \\
(\mathrm{cm})\end{array}$ & $(\mathrm{cm})$ \\
\hline M1 $(1448+1588+1760)$ & $40.8 \mathrm{abc} c^{\dagger}$ & $2.5 \mathrm{c}$ & $46.8 \mathrm{bcd}$ & $21.2 \mathrm{~b}$ & $4.5 \mathrm{a}$ \\
M2 $(907+1003+1214)$ & $60.0 \mathrm{a}$ & $8.2 \mathrm{a}$ & $120.5 \mathrm{ab}$ & $19.7 \mathrm{bc}$ & $5.0 \mathrm{a}$ \\
M3 $(864+907+1079+1229)$ & $14.2 \mathrm{c}$ & $3.3 \mathrm{c}$ & $47.3 \mathrm{bcd}$ & $14.0 \mathrm{~cd}$ & $4.7 \mathrm{a}$ \\
907 & $23.3 \mathrm{bc}$ & $5.5 \mathrm{abc}$ & $55.5 \mathrm{bcd}$ & $16.0 \mathrm{bcd}$ & $4.3 \mathrm{a}$ \\
1003 & $50.8 \mathrm{ab}$ & $4.5 \mathrm{abc}$ & $74.0 \mathrm{bcd}$ & $18.2 \mathrm{bcd}$ & $4.5 \mathrm{a}$ \\
1448 & $39.2 \mathrm{abc}$ & $5.3 \mathrm{abc}$ & $95.7 \mathrm{bc}$ & $20.8 \mathrm{~b}$ & $6.8 \mathrm{a}$ \\
1588 & $38.3 \mathrm{abc}$ & $3.4 \mathrm{bc}$ & $57.5 \mathrm{bcd}$ & $19.2 \mathrm{bcd}$ & $7.2 \mathrm{a}$ \\
1760 & $56.7 \mathrm{a}$ & $7.6 \mathrm{ab}$ & $174.2 \mathrm{a}$ & $18.7 \mathrm{bcd}$ & $7.2 \mathrm{a}$ \\
Reubens & $40.8 \mathrm{abc}$ & $3.7 \mathrm{bc}$ & $23.2 \mathrm{~cd}$ & $28.0 \mathrm{a}$ & $5.3 \mathrm{a}$ \\
Nugget & $10.8 \mathrm{c}$ & $1.3 \mathrm{c}$ & $5.8 \mathrm{~d}$ & $13.0 \mathrm{~d}$ & $5.5 \mathrm{a}$ \\
\hline \hline
\end{tabular}

${ }^{\dagger}$ Means within columns followed by the same letter are not significantly different by Duncan's new multiple range test $(P \leq 0.05)$. $n=6$ for all means. 
Table B.10. Performance of selected alpine bluegrass lines in multilocation trial 2 at Mountain Park in 1991, 1992 \& 1993. The trial was seeded in 1991.

\begin{tabular}{|c|c|c|c|c|}
\hline \multirow[b]{2}{*}{ Line } & \multirow{2}{*}{$\begin{array}{c}\text { Emergence } \\
\text { (no. plants } \mathrm{m}^{-1} \text { ) }\end{array}$} & \multicolumn{2}{|c|}{ Cover $(\%)$} & \multirow{2}{*}{$\begin{array}{c}\begin{array}{c}\text { Number of Heads } \\
\left(\text { no. } \mathrm{m}^{-1}\right)\end{array} \\
1993\end{array}$} \\
\hline & & 1992 & 1993 & \\
\hline M1 (1448+1588+1760) & $74 a^{\dagger}$ & $13.0 \mathrm{ab}$ & $13.3 \mathrm{a}$ & - \\
\hline M2 $(907+1003+1214)$ & $50 \mathrm{a}$ & $7.5 \mathrm{abc}$ & $12.8 \mathrm{a}$ & $1.5 \mathrm{a}$ \\
\hline M3 (864+907+1079+1229) & $46 a$ & $5.0 \mathrm{c}$ & $10.7 \mathrm{a}$ & - \\
\hline 907 & $72 \mathrm{a}$ & $6.3 \mathrm{bc}$ & $12.5 \mathrm{a}$ & $0.5 \mathrm{a}$ \\
\hline 1003 & $72 \mathrm{a}$ & $12.5 \mathrm{ab}$ & $20.0 \mathrm{a}$ & - \\
\hline 1448 & $55 \mathrm{a}$ & $10.8 \mathrm{abc}$ & $15.8 \mathrm{a}$ & - \\
\hline 1588 & $75 a$ & $13.3 \mathrm{a}$ & $19.2 \mathrm{a}$ & $0.5 \mathrm{a}$ \\
\hline 1760 & $45 a$ & $11.7 \mathrm{abc}$ & $20.0 \mathrm{a}$ & $1.0 \mathrm{a}$ \\
\hline Reubens & $89 a$ & $10.8 \mathrm{abc}$ & $17.0 \mathrm{a}$ & $2.0 \mathrm{a}$ \\
\hline Nugget & $86 a$ & $7.7 \mathrm{abc}$ & $12.3 \mathrm{a}$ & - \\
\hline
\end{tabular}

${ }^{\dagger}$ Means within columns followed by the same letter are not significantly different by Duncan's new multiple range test $(P \leq 0.05)$. $n=6$ for all means. 
Table B.11. Performance of selected alpine bluegrass lines in multilocation trial 2 at Mountain Park in 1994. The trial was seeded in 1991.

\begin{tabular}{|c|c|c|c|c|c|}
\hline Line & $\begin{array}{l}\text { Cover } \\
(\%)\end{array}$ & $\begin{array}{c}\text { Number of Heads } \\
\left(\text { no. } \mathrm{m}^{-1}\right)\end{array}$ & $\begin{array}{l}\text { Seed Yield } \\
\left(\mathrm{mg} \mathrm{m}^{-1}\right)\end{array}$ & $\begin{array}{l}\text { Plant Height } \\
\text { (cm) }\end{array}$ & $\begin{array}{l}\text { Plant Width } \\
(\mathrm{cm})\end{array}$ \\
\hline M1 (1448+1588+1760) & $38.3 \mathrm{a}^{\dagger}$ & $1.6 \mathrm{a}$ & $34.0 \mathrm{a}$ & $21.7 \mathrm{a}$ & $3.7 \mathrm{a}$ \\
\hline M2 $(907+1003+1214)$ & $24.2 \mathrm{a}$ & $0.8 \mathrm{a}$ & $15.0 \mathrm{a}$ & $18.8 \mathrm{a}$ & $3.2 \mathrm{a}$ \\
\hline M3 (864+907+1079+1229) & $15.8 \mathrm{a}$ & $1.3 \mathrm{a}$ & $12.8 \mathrm{a}$ & $15.5 \mathrm{a}$ & $2.8 \mathrm{a}$ \\
\hline 907 & $28.3 \mathrm{a}$ & $0.3 \mathrm{a}$ & $4.2 \mathrm{a}$ & $10.7 \mathrm{a}$ & $2.8 \mathrm{a}$ \\
\hline 1003 & $40.8 \mathrm{a}$ & $1.0 \mathrm{a}$ & $16.7 \mathrm{a}$ & $15.0 \mathrm{a}$ & $5.6 \mathrm{a}$ \\
\hline 1448 & $22.5 \mathrm{a}$ & $0.9 \mathrm{a}$ & $18.2 \mathrm{a}$ & $19.8 \mathrm{a}$ & $4.0 \mathrm{a}$ \\
\hline 1588 & $37.5 \mathrm{a}$ & $1.7 \mathrm{a}$ & $30.3 a$ & $19.0 \mathrm{a}$ & $3.3 \mathrm{a}$ \\
\hline 1760 & $36.7 \mathrm{a}$ & $3.4 \mathrm{a}$ & $70.7 \mathrm{a}$ & $20.8 \mathrm{a}$ & $4.5 \mathrm{a}$ \\
\hline Reubens & $24.2 \mathrm{a}$ & $4.3 \mathrm{a}$ & $19.2 \mathrm{a}$ & $18.6 \mathrm{a}$ & $6.0 \mathrm{a}$ \\
\hline Nugget & $23.3 \mathrm{a}$ & $0.3 \mathrm{a}$ & $2.2 \mathrm{a}$ & $11.0 \mathrm{a}$ & $3.7 \mathrm{a}$ \\
\hline
\end{tabular}

${ }^{\dagger}$ Means within columns followed by the same letter are not significantly different by Duncan's new multiple range test $(P \leq 0.05)$. $n=6$ for all means. 
Table B.12. Performance of selected alpine bluegrass lines in multilocation trial 1 at Vegreville in 1991. The trial was seeded in 1990.

\begin{tabular}{lcccccc}
\hline \hline Line & $\begin{array}{c}\text { Survival } \\
(\%)\end{array}$ & $\begin{array}{c}\text { Number of } \\
\text { Heads } \\
\left(\mathrm{no} . \mathrm{m}^{-1}\right)\end{array}$ & $\begin{array}{c}\text { Seed } \\
\text { Yield } \\
\left(\mathrm{kg} \mathrm{ha}^{-1}\right)\end{array}$ & $\begin{array}{c}\text { Plant } \\
\text { Height } \\
(\mathrm{cm})\end{array}$ & $\begin{array}{c}\text { Time to } \\
\text { Maturity } \\
(\text { days }\end{array}$ & $\begin{array}{c}1000 \text { Seed } \\
\text { Weight } \\
(\mathrm{mg})\end{array}$ \\
\hline M1 (1448+1588+1760) & $81 \mathrm{ab}^{\ddagger}$ & $295 \mathrm{bc}$ & $224 \mathrm{ab}$ & $32.2 \mathrm{~cd}$ & $78 \mathrm{de}$ & $521 \mathrm{a}$ \\
M2 $(907+1003+1214)$ & $64 \mathrm{bc}$ & $125 \mathrm{def}$ & $83 \mathrm{de}$ & $30.3 \mathrm{~cd}$ & $78 \mathrm{e}$ & $507 \mathrm{ab}$ \\
M3 $(864+907+1079+1229)$ & $52 \mathrm{c}$ & $80 \mathrm{ef}$ & $46 \mathrm{e}$ & $29.8 \mathrm{~d}$ & $74 \mathrm{f}$ & $527 \mathrm{a}$ \\
907 & $52 \mathrm{c}$ & $47 \mathrm{f}$ & $26 \mathrm{e}$ & $26.3 \mathrm{e}$ & $70 \mathrm{~g}$ & $500 \mathrm{ab}$ \\
1003 & $72 \mathrm{abc}$ & $84 \mathrm{ef}$ & $108 \mathrm{cde}$ & $30.2 \mathrm{~d}$ & $78 \mathrm{e}$ & $536 \mathrm{a}$ \\
1448 & $87 \mathrm{a}$ & $250 \mathrm{~cd}$ & $181 \mathrm{bc}$ & $33.5 \mathrm{bc}$ & $80 \mathrm{~cd}$ & $477 \mathrm{~b}$ \\
1588 & $77 \mathrm{ab}$ & $244 \mathrm{~cd}$ & $156 \mathrm{bcd}$ & $30.7 \mathrm{~cd}$ & $80 \mathrm{c}$ & $475 \mathrm{~b}$ \\
1760 & $83 \mathrm{ab}$ & $231 \mathrm{cde}$ & $155 \mathrm{bcd}$ & $30.5 \mathrm{~cd}$ & $79 \mathrm{cde}$ & $516 \mathrm{ab}$ \\
Reubens & $74 \mathrm{abc}$ & $560 \mathrm{a}$ & $234 \mathrm{ab}$ & $52.5 \mathrm{a}$ & $99 \mathrm{a}$ & $374 \mathrm{c}$ \\
Nugget & $61 \mathrm{bc}$ & $431 \mathrm{ab}$ & $282 \mathrm{a}$ & $36.0 \mathrm{~b}$ & $87 \mathrm{~b}$ & $537 \mathrm{a}$ \\
\hline \hline
\end{tabular}

${ }^{\dagger}$ Days from April 15 to maturity.

${ }^{\ddagger}$ Means within columns followed by the same letter are not significantly different by Duncan's new multiple range test $(P \leq 0.05)$. $n=6$ for all means. 
Table B.13. Performance of selected alpine bluegrass lines in multilocation trial 1 at Vegreville in 1992. The trial was seeded in 1990.

\begin{tabular}{lcccccc}
\hline \hline Line & $\begin{array}{c}\text { Survival } \\
(\%)\end{array}$ & $\begin{array}{c}\text { Number of } \\
\text { Heads } \\
\left(\text { no. m }^{-1}\right)\end{array}$ & $\begin{array}{c}\text { Seed } \\
\text { Yield } \\
\left(\mathrm{kg} \mathrm{ha}^{-1}\right)\end{array}$ & $\begin{array}{c}\text { Plant } \\
\text { Height } \\
(\mathrm{cm})\end{array}$ & $\begin{array}{c}\text { Time to } \\
\text { Maturity } \\
(\text { days })\end{array}$ & $\begin{array}{c}1000 \text { Seed } \\
\text { Weight } \\
(\mathrm{mg})\end{array}$ \\
\hline M1 $(1448+1588+1760)$ & $51 \mathrm{c}^{\ddagger}$ & $108 \mathrm{~b}$ & $12 \mathrm{~b}$ & $38.1 \mathrm{~b}$ & $83 \mathrm{c}$ & $494 \mathrm{abc}$ \\
M2 $(907+1003+1214)$ & $88 \mathrm{ab}$ & $231 \mathrm{~b}$ & $48 \mathrm{~b}$ & $35.3 \mathrm{bc}$ & $76 \mathrm{~d}$ & $424 \mathrm{bc}$ \\
M3 $(864+907+1079+1229)$ & $43 \mathrm{c}$ & $144 \mathrm{~b}$ & $25 \mathrm{~b}$ & $34.0 \mathrm{bc}$ & $72 \mathrm{de}$ & $478 \mathrm{abc}$ \\
907 & $61 \mathrm{bc}$ & $160 \mathrm{~b}$ & $36 \mathrm{~b}$ & $32.2 \mathrm{c}$ & $68 \mathrm{e}$ & $382 \mathrm{c}$ \\
1003 & $68 \mathrm{abc}$ & $171 \mathrm{~b}$ & $75 \mathrm{~b}$ & $37.5 \mathrm{bc}$ & $73 \mathrm{~d}$ & $553 \mathrm{a}$ \\
1448 & $42 \mathrm{c}$ & $74 \mathrm{~b}$ & $3 \mathrm{~b}$ & $36.4 \mathrm{bc}$ & $83 \mathrm{c}$ & $537 \mathrm{ab}$ \\
1588 & $50 \mathrm{c}$ & $156 \mathrm{~b}$ & $18 \mathrm{~b}$ & $32.2 \mathrm{c}$ & $83 \mathrm{c}$ & $528 \mathrm{ab}$ \\
1760 & $35 \mathrm{c}$ & $127 \mathrm{~b}$ & $17 \mathrm{~b}$ & $34.2 \mathrm{bc}$ & $82 \mathrm{c}$ & $510 \mathrm{ab}$ \\
Reubens & $100 \mathrm{a}$ & $1820 \mathrm{a}$ & $228 \mathrm{a}$ & $46.2 \mathrm{a}$ & $103 \mathrm{a}$ & $449 \mathrm{abc}$ \\
Nugget & $64 \mathrm{bc}$ & $255 \mathrm{~b}$ & $18 \mathrm{~b}$ & $35.0 \mathrm{bc}$ & $95 \mathrm{~b}$ & $554 \mathrm{a}$ \\
\hline \hline
\end{tabular}

${ }^{\dagger}$ Days from April 15 to maturity.

${ }^{\ddagger}$ Means within columns followed by the same letter are not significantly different by Duncan's new multiple range test $(\mathrm{P} \leq 0.05)$. $\mathrm{n}=6$ for all means. 
Table B.14. Performance of selected alpine bluegrass lines in multilocation trial 2 at Vegreville in 1992. The trial was seeded in 1991.

\begin{tabular}{lcccccc}
\hline \hline Line & $\begin{array}{c}\text { Survival } \\
(\%)\end{array}$ & $\begin{array}{c}\text { Number of } \\
\text { Heads } \\
\left(\text { no. m }^{-1}\right)\end{array}$ & $\begin{array}{c}\text { Seed } \\
\text { Yield } \\
\left(\mathrm{kg} \mathrm{ha}^{-1}\right)\end{array}$ & $\begin{array}{c}\text { Plant } \\
\text { Height } \\
(\mathrm{cm})\end{array}$ & $\begin{array}{c}\text { Time to } \\
\text { Maturity } \\
(\text { days })^{\dagger}\end{array}$ & $\begin{array}{c}1000 \text { Seed } \\
\text { Weight } \\
(\mathrm{mg})\end{array}$ \\
\hline M1 (1448+1588+1760) & $89 \mathrm{bc}^{\ddagger}$ & $264 \mathrm{c}$ & $109 \mathrm{~d}$ & $30.3 \mathrm{de}$ & $83 \mathrm{c}$ & $542 \mathrm{~b}$ \\
M2 $(907+1003+1214)$ & $94 \mathrm{abc}$ & $197 \mathrm{c}$ & $217 \mathrm{~b}$ & $32.8 \mathrm{~cd}$ & $72 \mathrm{de}$ & $514 \mathrm{~b}$ \\
M3 $(864+907+1079+1229)$ & $87 \mathrm{c}$ & $227 \mathrm{c}$ & $207 \mathrm{bc}$ & $32.2 \mathrm{cde}$ & $71 \mathrm{e}$ & $499 \mathrm{~b}$ \\
907 & $88 \mathrm{c}$ & $213 \mathrm{c}$ & $253 \mathrm{~b}$ & $29.2 \mathrm{e}$ & $69 \mathrm{e}$ & $455 \mathrm{~b}$ \\
1003 & $96 \mathrm{ab}$ & $179 \mathrm{c}$ & $393 \mathrm{a}$ & $34.6 \mathrm{bc}$ & $74 \mathrm{~d}$ & $548 \mathrm{~b}$ \\
1448 & $94 \mathrm{abc}$ & $264 \mathrm{c}$ & $63 \mathrm{~d}$ & $31.4 \mathrm{cde}$ & $85 \mathrm{c}$ & $539 \mathrm{~b}$ \\
1588 & $96 \mathrm{ab}$ & $290 \mathrm{c}$ & $108 \mathrm{~d}$ & $29.4 \mathrm{de}$ & $85 \mathrm{c}$ & $522 \mathrm{~b}$ \\
1760 & $95 \mathrm{ab}$ & $254 \mathrm{c}$ & $124 \mathrm{~cd}$ & $30.2 \mathrm{de}$ & $85 \mathrm{c}$ & $561 \mathrm{~b}$ \\
Reubens & $100 \mathrm{a}$ & $892 \mathrm{a}$ & $207 \mathrm{bc}$ & $39.5 \mathrm{a}$ & $103 \mathrm{a}$ & $498 \mathrm{~b}$ \\
Nugget & $92 \mathrm{abc}$ & $482 \mathrm{~b}$ & $75 \mathrm{~d}$ & $36.8 \mathrm{ab}$ & $96 \mathrm{~b}$ & $696 \mathrm{a}$ \\
\hline \hline
\end{tabular}

${ }^{\dagger}$ Days from April 15 to maturity.

${ }^{\ddagger}$ Means within columns followed by the same letter are not significantly different by Duncan's new multiple range test $(P \leq 0.05)$. $n=6$ for all means. 
Table B.15. Performance of selected alpine bluegrass lines in multilocation trial 2 at Vegreville in 1993. The trial was seeded in 1991.

\begin{tabular}{lcccccc}
\hline \hline Line & $\begin{array}{c}\text { Survival } \\
(\%)\end{array}$ & $\begin{array}{c}\text { Number of } \\
(\text { Heads } \\
\left(\text { no. }^{-1}\right)\end{array}$ & $\begin{array}{c}\text { Seed } \\
\text { Yield } \\
\left(\mathrm{kg} \mathrm{ha}^{-1}\right)\end{array}$ & $\begin{array}{c}\text { Plant } \\
\text { Height } \\
(\mathrm{cm})\end{array}$ & $\begin{array}{c}\text { Time to } \\
\text { Maturity } \\
(\text { days })^{\dagger}\end{array}$ & $\begin{array}{c}1000 \text { Seed } \\
\text { Weight } \\
(\mathrm{mg})\end{array}$ \\
\hline M1 (1448+1588+1760) & $99 \mathrm{a}^{\ddagger}$ & $126 \mathrm{c}$ & $139 \mathrm{~b}$ & $36.2 \mathrm{~d}$ & $74 \mathrm{c}$ & $563 \mathrm{~b}$ \\
M2 (907+1003+1214) & $91 \mathrm{ab}$ & $165 \mathrm{c}$ & $323 \mathrm{a}$ & $41.5 \mathrm{~b}$ & $71 \mathrm{~d}$ & $566 \mathrm{~b}$ \\
M3 (864+907+1079+1229) & $83 \mathrm{ab}$ & $173 \mathrm{c}$ & $157 \mathrm{~b}$ & $41.2 \mathrm{~b}$ & $71 \mathrm{~d}$ & $568 \mathrm{~b}$ \\
907 & $76 \mathrm{~b}$ & $162 \mathrm{c}$ & $119 \mathrm{~b}$ & $39.7 \mathrm{bc}$ & $71 \mathrm{~d}$ & $557 \mathrm{~b}$ \\
1003 & $100 \mathrm{a}$ & $157 \mathrm{c}$ & $298 \mathrm{a}$ & $40.1 \mathrm{bc}$ & $72 \mathrm{~d}$ & $615 \mathrm{a}$ \\
1448 & $98 \mathrm{a}$ & $146 \mathrm{c}$ & $68 \mathrm{~b}$ & $37.4 \mathrm{~cd}$ & $75 \mathrm{c}$ & $555 \mathrm{~b}$ \\
1588 & $99 \mathrm{a}$ & $157 \mathrm{c}$ & $73 \mathrm{~b}$ & $32.8 \mathrm{e}$ & $75 \mathrm{c}$ & $546 \mathrm{~b}$ \\
1760 & $100 \mathrm{a}$ & $179 \mathrm{c}$ & $118 \mathrm{~b}$ & $35.6 \mathrm{~d}$ & $75 \mathrm{c}$ & $580 \mathrm{ab}$ \\
Reubens & $100 \mathrm{a}$ & $1502 \mathrm{a}$ & $288 \mathrm{a}$ & $69.0 \mathrm{a}$ & $116 \mathrm{a}$ & $231 \mathrm{c}$ \\
Nugget & $99 \mathrm{a}$ & $405 \mathrm{~b}$ & $325 \mathrm{a}$ & $42.7 \mathrm{~b}$ & $96 \mathrm{~b}$ & $584 \mathrm{ab}$ \\
\hline \hline
\end{tabular}

'Days from April 15 to maturity.

${ }^{\ddagger}$ Means within columns followed by the same letter are not significantly different by Duncan's new multiple range test $(\mathrm{P} \leq 0.05)$. $\mathrm{n}=6$ for all means. 
Table B.16. Performance of selected alpine bluegrass lines in multilocation trial 2 at Vegreville in 1994. The trial was seeded in 1991.

\begin{tabular}{lcccccc}
\hline \hline Line & $\begin{array}{c}\text { Survival } \\
(\%)\end{array}$ & $\begin{array}{c}\text { Number of } \\
\text { Heads } \\
\left(\mathrm{no} \mathrm{m}^{-1}\right)\end{array}$ & $\begin{array}{c}\text { Seed } \\
\text { Yield } \\
\left(\mathrm{kg} \mathrm{ha}^{-1}\right)\end{array}$ & $\begin{array}{c}\text { Plant } \\
\text { Height } \\
(\mathrm{cm})\end{array}$ & $\begin{array}{c}\text { Time to } \\
\text { Maturity } \\
\left(\text { days }^{\dagger}\right)\end{array}$ & $\begin{array}{c}1000 \text { Seed } \\
\text { Weight } \\
(\mathrm{mg})\end{array}$ \\
\hline M1 (1448+1588+1760) & $99 \mathrm{a}^{\ddagger}$ & $148 \mathrm{~b}$ & $39 \mathrm{bcd}$ & $42.6 \mathrm{bc}$ & $82 \mathrm{bc}$ & $437 \mathrm{c}$ \\
M2 $(907+1003+1214)$ & $94 \mathrm{a}$ & $201 \mathrm{~b}$ & $118 \mathrm{a}$ & $40.3 \mathrm{bcd}$ & $68 \mathrm{~d}$ & $441 \mathrm{c}$ \\
M3 (864+907+1079+1229) & $85 \mathrm{ab}$ & $176 \mathrm{~b}$ & $56 \mathrm{bc}$ & $35.8 \mathrm{~d}$ & $68 \mathrm{~d}$ & $468 \mathrm{bc}$ \\
907 & $72 \mathrm{~b}$ & $216 \mathrm{~b}$ & $73 \mathrm{~b}$ & $37.4 \mathrm{~cd}$ & $67 \mathrm{~d}$ & $437 \mathrm{c}$ \\
1003 & $97 \mathrm{a}$ & $215 \mathrm{~b}$ & $147 \mathrm{a}$ & $42.4 \mathrm{bc}$ & $70 \mathrm{~d}$ & $502 \mathrm{ab}$ \\
1448 & $98 \mathrm{a}$ & $128 \mathrm{~b}$ & $12 \mathrm{~d}$ & $43.0 \mathrm{~b}$ & $84 \mathrm{~b}$ & $467 \mathrm{bc}$ \\
1588 & $99 \mathrm{a}$ & $152 \mathrm{~b}$ & $21 \mathrm{~cd}$ & $42.8 \mathrm{bc}$ & $83 \mathrm{bc}$ & $459 \mathrm{bc}$ \\
1760 & $98 \mathrm{a}$ & $181 \mathrm{~b}$ & $33 \mathrm{bcd}$ & $42.3 \mathrm{bc}$ & $79 \mathrm{c}$ & $472 \mathrm{bc}$ \\
Reubens & $100 \mathrm{a}$ & $970 \mathrm{a}$ & $21 \mathrm{~cd}$ & $76.0 \mathrm{a}$ & $104 \mathrm{a}$ & $276 \mathrm{~d}$ \\
Nugget & $95 \mathrm{a}$ & $231 \mathrm{~b}$ & $7 \mathrm{~d}$ & $44.1 \mathrm{~b}$ & $102 \mathrm{a}$ & $535 \mathrm{a}$ \\
\hline \hline
\end{tabular}

${ }^{\dagger}$ Days from April 15 to maturity.

${ }^{\ddagger}$ Means within columns followed by the same letter are not significantly different by Duncan's new multiple range test $(P \leq 0.05)$. $n=6$ for all means. 
Table B.17. Performance of selected alpine bluegrass lines in multilocation trial 3 at Vegreville in 1993. The trial was seeded in 1992.

\begin{tabular}{lcccccc}
\hline \hline Line & $\begin{array}{c}\text { Survival } \\
(\%)\end{array}$ & $\begin{array}{c}\text { Number of } \\
\text { Heads } \\
\left(\text { no m }^{-1}\right)\end{array}$ & $\begin{array}{c}\text { Seed } \\
\text { Yield } \\
\left(\mathrm{kg} \mathrm{ha}^{-1}\right)\end{array}$ & $\begin{array}{c}\text { Plant } \\
\text { Height } \\
(\mathrm{cm})\end{array}$ & $\begin{array}{c}\text { Time to } \\
\text { Maturity } \\
\left(\text { days }^{\dagger}\right)\end{array}$ & $\begin{array}{c}1000 \text { Seed } \\
(\mathrm{mg})\end{array}$ \\
\hline M1 $(1448+1588+1760)$ & $100 \mathrm{a}^{\ddagger}$ & $276 \mathrm{c}$ & $476 \mathrm{~cd}$ & $35.6 \mathrm{~cd}$ & $82 \mathrm{c}$ & $483 \mathrm{~cd}$ \\
M2 $(907+1003+1214)$ & $100 \mathrm{a}$ & $382 \mathrm{bc}$ & $919 \mathrm{ab}$ & $34.6 \mathrm{~d}$ & $76 \mathrm{~d}$ & $506 \mathrm{bc}$ \\
M3 $(864+907+1079+1229)$ & $100 \mathrm{a}$ & $332 \mathrm{bc}$ & $838 \mathrm{~b}$ & $41.0 \mathrm{~b}$ & $71 \mathrm{e}$ & $502 \mathrm{bc}$ \\
907 & $100 \mathrm{a}$ & $442 \mathrm{~b}$ & $1031 \mathrm{a}$ & $35.7 \mathrm{~cd}$ & $67 \mathrm{e}$ & $478 \mathrm{~cd}$ \\
1003 & $100 \mathrm{a}$ & $346 \mathrm{bc}$ & $1072 \mathrm{a}$ & $37.7 \mathrm{bcd}$ & $71 \mathrm{e}$ & $531 \mathrm{~b}$ \\
1448 & $100 \mathrm{a}$ & $301 \mathrm{c}$ & $547 \mathrm{c}$ & $38.3 \mathrm{bcd}$ & $82 \mathrm{c}$ & $467 \mathrm{de}$ \\
1588 & $100 \mathrm{a}$ & $274 \mathrm{c}$ & $553 \mathrm{c}$ & $34.9 \mathrm{~cd}$ & $82 \mathrm{c}$ & $442 \mathrm{e}$ \\
1760 & $100 \mathrm{a}$ & $301 \mathrm{c}$ & $613 \mathrm{c}$ & $36.8 \mathrm{bcd}$ & $82 \mathrm{c}$ & $465 \mathrm{de}$ \\
Reubens & $100 \mathrm{a}$ & $660 \mathrm{a}$ & $351 \mathrm{~d}$ & $61.7 \mathrm{a}$ & $115 \mathrm{a}$ & $226 \mathrm{f}$ \\
Nugget & $100 \mathrm{a}$ & $601 \mathrm{a}$ & $538 \mathrm{c}$ & $39.4 \mathrm{bc}$ & $98 \mathrm{~b}$ & $578 \mathrm{a}$ \\
\hline \hline
\end{tabular}

${ }^{\dagger}$ Days from April 15 to maturity.

${ }^{\ddagger}$ Means within columns followed by the same letter are not significantly different by Duncan's new multiple range test $(P \leq 0.05)$. $n=6$ for all means. 
Table B.18. Performance of selected alpine bluegrass lines in multilocation trial 3 at Vegreville in 1994. The trial was seeded in 1992.

\begin{tabular}{lcccccc}
\hline \hline Line & $\begin{array}{c}\text { Survival } \\
(\%)\end{array}$ & $\begin{array}{c}\text { Number of } \\
\text { Heads } \\
\left(\text { no m }^{-1}\right)\end{array}$ & $\begin{array}{c}\text { Seed } \\
\text { Yield } \\
\left(\mathrm{kg} \mathrm{ha}^{-1}\right)\end{array}$ & $\begin{array}{c}\text { Plant } \\
\text { Height } \\
(\mathrm{cm})\end{array}$ & $\begin{array}{c}\text { Time to } \\
\text { Maturity } \\
\left(\text { days }^{\dagger}\right)\end{array}$ & $\begin{array}{c}1000 \text { Seed } \\
\text { Weight } \\
(\mathrm{mg})\end{array}$ \\
\hline M1 (1448+1588+1760) & $93 \mathrm{ab}^{\ddagger}$ & $106 \mathrm{~b}$ & $22 \mathrm{~d}$ & $36.5 \mathrm{c}$ & $87 \mathrm{c}$ & $497 \mathrm{a}$ \\
M2 $(907+1003+1214)$ & $98 \mathrm{a}$ & $152 \mathrm{~b}$ & $82 \mathrm{ab}$ & $33.9 \mathrm{~cd}$ & $78 \mathrm{~d}$ & $510 \mathrm{a}$ \\
M3 $(864+907+1079+1229)$ & $95 \mathrm{a}$ & $124 \mathrm{~b}$ & $23 \mathrm{~d}$ & $33.0 \mathrm{~cd}$ & $73 \mathrm{~d}$ & $478 \mathrm{a}$ \\
907 & $86 \mathrm{~b}$ & $131 \mathrm{~b}$ & $29 \mathrm{~cd}$ & $30.3 \mathrm{~d}$ & $73 \mathrm{~d}$ & $476 \mathrm{a}$ \\
1003 & $98 \mathrm{a}$ & $152 \mathrm{~b}$ & $102 \mathrm{a}$ & $36.5 \mathrm{c}$ & $73 \mathrm{~d}$ & $533 \mathrm{a}$ \\
1448 & $99 \mathrm{a}$ & $418 \mathrm{~b}$ & $20 \mathrm{~d}$ & $37.8 \mathrm{c}$ & $87 \mathrm{c}$ & $496 \mathrm{a}$ \\
1588 & $98 \mathrm{a}$ & $147 \mathrm{~b}$ & $42 \mathrm{bcd}$ & $36.2 \mathrm{c}$ & $87 \mathrm{c}$ & $458 \mathrm{a}$ \\
1760 & $98 \mathrm{a}$ & $144 \mathrm{~b}$ & $60 \mathrm{bcd}$ & $37.9 \mathrm{c}$ & $87 \mathrm{c}$ & $456 \mathrm{a}$ \\
Reubens & $100 \mathrm{a}$ & $1060 \mathrm{a}$ & $55 \mathrm{bcd}$ & $62.0 \mathrm{a}$ & $104 \mathrm{a}$ & $311 \mathrm{~b}$ \\
Nugget & $100 \mathrm{a}$ & $383 \mathrm{~b}$ & $69 \mathrm{abc}$ & $47.5 \mathrm{~b}$ & $95 \mathrm{~b}$ & $514 \mathrm{a}$ \\
\hline \hline
\end{tabular}

${ }^{\dagger}$ Days from April 15 to maturity.

${ }^{\ddagger}$ Means within columns followed by the same letter are not significantly different by Duncan's new multiple range test $(\mathrm{P} \leq 0.05)$. $\mathrm{n}=6$ for all means. 
Table B.19. Performance of selected alpine bluegrass lines in multilocation trial 2 at Beaverlodge in 1992. The trial was seeded in 1991.

\begin{tabular}{lcccccc}
\hline \hline Line & $\begin{array}{c}\text { Survival } \\
(\%)\end{array}$ & $\begin{array}{c}\text { Number of } \\
\text { Heads } \\
\left(\mathrm{no} \mathrm{m}^{-1}\right)\end{array}$ & $\begin{array}{c}\text { Seed } \\
\text { Yield } \\
\left(\mathrm{kg} \mathrm{ha}^{-1}\right)\end{array}$ & $\begin{array}{c}\text { Plant } \\
\text { Height } \\
(\mathrm{cm})\end{array}$ & $\begin{array}{c}\text { Time to } \\
\text { Maturity } \\
\left(\text { days }^{\dagger}\right)\end{array}$ & $\begin{array}{c}\text { Weight } \\
(\mathrm{mg})\end{array}$ \\
\hline M1 (1448+1588+1760) & $100 \mathrm{a}^{\ddagger}$ & $136 \mathrm{~b}$ & $56 \mathrm{~b}$ & $29.4 \mathrm{~b}$ & $75 \mathrm{c}$ & $553 \mathrm{bc}$ \\
M2 (907+1003+1214) & $100 \mathrm{a}$ & $116 \mathrm{~b}$ & $52 \mathrm{~b}$ & $25.3 \mathrm{cde}$ & $75 \mathrm{c}$ & $565 \mathrm{abc}$ \\
M3 (864+907+1079+1229) & $100 \mathrm{a}$ & $161 \mathrm{~b}$ & $63 \mathrm{~b}$ & $25.7 \mathrm{cde}$ & $75 \mathrm{c}$ & $517 \mathrm{bcd}$ \\
907 & $100 \mathrm{a}$ & $180 \mathrm{~b}$ & $85 \mathrm{~b}$ & $24.6 \mathrm{de}$ & $75 \mathrm{c}$ & $468 \mathrm{~cd}$ \\
1003 & $100 \mathrm{a}$ & $154 \mathrm{~b}$ & $87 \mathrm{~b}$ & $27.6 \mathrm{bcd}$ & $75 \mathrm{c}$ & $578 \mathrm{ab}$ \\
1448 & $100 \mathrm{a}$ & $150 \mathrm{~b}$ & $28 \mathrm{~b}$ & $30.5 \mathrm{~b}$ & $75 \mathrm{c}$ & $553 \mathrm{bc}$ \\
1588 & $100 \mathrm{a}$ & $214 \mathrm{~b}$ & $64 \mathrm{~b}$ & $28.3 \mathrm{bc}$ & $75 \mathrm{c}$ & $498 \mathrm{bcd}$ \\
1760 & $100 \mathrm{a}$ & $196 \mathrm{~b}$ & $56 \mathrm{~b}$ & $29.3 \mathrm{~b}$ & $82 \mathrm{~b}$ & $556 \mathrm{bc}$ \\
Reubens & $100 \mathrm{a}$ & $420 \mathrm{a}$ & $238 \mathrm{a}$ & $42.2 \mathrm{a}$ & $97 \mathrm{a}$ & $429 \mathrm{~d}$ \\
Nugget & $98 \mathrm{a}$ & $101 \mathrm{~b}$ & $45 \mathrm{~b}$ & $23.8 \mathrm{e}$ & $97 \mathrm{a}$ & $658 \mathrm{a}$ \\
\hline \hline
\end{tabular}

${ }^{\dagger}$ Days from April 15 to maturity.

${ }^{\ddagger}$ Means within columns followed by the same letter are not significantly different by Duncan's new multiple range test $(P \leq 0.05)$. $n=6$ for all means. 
Table B.20. Performance of selected alpine bluegrass lines in multilocation trial 2 at Beaverlodge in 1993. The trial was seeded in 1991.

\begin{tabular}{lcccccc}
\hline \hline Line & $\begin{array}{c}\text { Survival } \\
(\%)\end{array}$ & $\begin{array}{c}\text { Number of } \\
\text { Heads } \\
\left(\text { no m }^{-1}\right)\end{array}$ & $\begin{array}{c}\text { Seed } \\
\text { Yield } \\
\left(\mathrm{kg} \mathrm{ha}^{-1}\right)\end{array}$ & $\begin{array}{c}\text { Plant } \\
\text { Height } \\
(\mathrm{cm})\end{array}$ & $\begin{array}{c}\text { Time to } \\
\text { Maturity } \\
(\text { days }\end{array}$ & $\begin{array}{c}\text { 1000 Seed } \\
\text { Weight } \\
(\mathrm{mg})\end{array}$ \\
\hline M1 (1448+1588+1760) & $72 \mathrm{cde}^{\ddagger}$ & $152 \mathrm{c}$ & $194 \mathrm{bc}$ & $31.7 \mathrm{~b}$ & $68 \mathrm{c}$ & $474 \mathrm{~b}$ \\
M2 $(907+1003+1214)$ & $79 \mathrm{bcd}$ & $145 \mathrm{c}$ & $252 \mathrm{ab}$ & $30.6 \mathrm{~b}$ & $68 \mathrm{c}$ & $522 \mathrm{ab}$ \\
M3 $(864+907+1079+1229)$ & $62 \mathrm{de}$ & $123 \mathrm{c}$ & $205 \mathrm{bc}$ & $31.4 \mathrm{~b}$ & $68 \mathrm{c}$ & $460 \mathrm{~b}$ \\
907 & $69 \mathrm{cde}$ & $168 \mathrm{c}$ & $198 \mathrm{bc}$ & $30.0 \mathrm{~b}$ & $68 \mathrm{c}$ & $488 \mathrm{~b}$ \\
1003 & $88 \mathrm{abc}$ & $132 \mathrm{c}$ & $338 \mathrm{a}$ & $31.6 \mathrm{~b}$ & $68 \mathrm{c}$ & $499 \mathrm{~b}$ \\
1448 & $66 \mathrm{de}$ & $145 \mathrm{c}$ & $214 \mathrm{bc}$ & $31.6 \mathrm{~b}$ & $68 \mathrm{c}$ & $489 \mathrm{~b}$ \\
1588 & $58 \mathrm{e}$ & $169 \mathrm{c}$ & $115 \mathrm{c}$ & $29.1 \mathrm{~b}$ & $68 \mathrm{c}$ & $490 \mathrm{~b}$ \\
1760 & $73 \mathrm{cde}$ & $182 \mathrm{c}$ & $242 \mathrm{abc}$ & $32.5 \mathrm{~b}$ & $68 \mathrm{c}$ & $488 \mathrm{~b}$ \\
Reubens & $100 \mathrm{a}$ & $1146 \mathrm{a}$ & $166 \mathrm{bc}$ & $39.6 \mathrm{a}$ & $117 \mathrm{a}$ & $243 \mathrm{c}$ \\
Nugget & $96 \mathrm{ab}$ & $292 \mathrm{~b}$ & $152 \mathrm{bc}$ & $36.3 \mathrm{a}$ & $104 \mathrm{~b}$ & $583 \mathrm{a}$ \\
\hline \hline
\end{tabular}

${ }^{\dagger}$ Days from April 15 to maturity.

${ }^{\ddagger}$ Means within columns followed by the same letter are not significantly different by Duncan's new multiple range test $(P \leq 0.05) . n=6$ for all means. 
Table B.21. Performance of selected alpine bluegrass lines in multilocation trial 3 at Plamondon in 1993. The trial was seeded in 1992.

\begin{tabular}{lcccccc}
\hline \hline Line & $\begin{array}{c}\text { Survival } \\
(\%)\end{array}$ & $\begin{array}{c}\text { Number of } \\
\text { Heads } \\
\left(\text { no m }^{-1}\right)\end{array}$ & $\begin{array}{c}\text { Seed } \\
\text { Yield } \\
\left(\mathrm{kg} \mathrm{ha}^{-1}\right)\end{array}$ & $\begin{array}{c}\text { Plant } \\
\text { Height } \\
(\mathrm{cm})\end{array}$ & $\begin{array}{c}\text { Time to } \\
\text { Maturity } \\
\left(\text { days }^{\dagger}\right)\end{array}$ & $\begin{array}{c}\text { Weog Seed } \\
(\mathrm{mg})\end{array}$ \\
\hline M1 $(1448+1588+1760)$ & $100 \mathrm{a}^{\ddagger}$ & $97 \mathrm{c}$ & $73 \mathrm{~cd}$ & $35.4 \mathrm{~b}$ & $83 \mathrm{~b}$ & $265 \mathrm{a}$ \\
M2 $(907+1003+1214)$ & $100 \mathrm{a}$ & $174 \mathrm{~b}$ & $160 \mathrm{a}$ & $34.1 \mathrm{bc}$ & $76 \mathrm{c}$ & $257 \mathrm{a}$ \\
M3 $(864+907+1079+1229)$ & $100 \mathrm{a}$ & $115 \mathrm{bc}$ & $82 \mathrm{bcd}$ & $33.3 \mathrm{bc}$ & $76 \mathrm{c}$ & $251 \mathrm{a}$ \\
907 & $100 \mathrm{a}$ & $116 \mathrm{bc}$ & $70 \mathrm{~cd}$ & $31.8 \mathrm{bc}$ & $76 \mathrm{c}$ & $238 \mathrm{a}$ \\
1003 & $100 \mathrm{a}$ & $72 \mathrm{c}$ & $142 \mathrm{ab}$ & $33.8 \mathrm{bc}$ & $76 \mathrm{c}$ & $263 \mathrm{a}$ \\
1448 & $100 \mathrm{a}$ & $103 \mathrm{bc}$ & $68 \mathrm{~cd}$ & $36.3 \mathrm{~b}$ & $83 \mathrm{~b}$ & $269 \mathrm{a}$ \\
1588 & $100 \mathrm{a}$ & $118 \mathrm{bc}$ & $77 \mathrm{bcd}$ & $32.3 \mathrm{bc}$ & $83 \mathrm{~b}$ & $240 \mathrm{a}$ \\
1760 & $100 \mathrm{a}$ & $125 \mathrm{bc}$ & $108 \mathrm{abc}$ & $32.9 \mathrm{bc}$ & $83 \mathrm{~b}$ & $252 \mathrm{a}$ \\
Reubens & $100 \mathrm{a}$ & $361 \mathrm{a}$ & $107 \mathrm{abc}$ & $48.3 \mathrm{a}$ & $92 \mathrm{a}$ & $127 \mathrm{~b}$ \\
Nugget & $100 \mathrm{a}$ & $68 \mathrm{c}$ & $25 \mathrm{~d}$ & $30.2 \mathrm{c}$ & $92 \mathrm{a}$ & $261 \mathrm{a}$ \\
\hline \hline
\end{tabular}

${ }^{\dagger}$ Days from April 15 to maturity.

${ }^{\ddagger}$ Means within columns followed by the same letter are not significantly different by Duncan's new multiple range test $(\mathrm{P} \leq 0.05)$. $\mathrm{n}=4$ for all means. 
Table B.22. Performance of selected alpine bluegrass lines in multilocation trial 3 at Plamondon in 1994. The trial was seeded in 1992.

\begin{tabular}{lcccccc}
\hline \hline Line & $\begin{array}{c}\text { Survival } \\
(\%)\end{array}$ & $\begin{array}{c}\text { Number of } \\
\text { Heads } \\
\left(\mathrm{no} \mathrm{m}^{-1}\right)\end{array}$ & $\begin{array}{c}\text { Seed } \\
\text { Yield } \\
\left(\mathrm{kg} \mathrm{ha}^{-1}\right)\end{array}$ & $\begin{array}{c}\text { Plant } \\
\text { Height } \\
(\mathrm{cm})\end{array}$ & $\begin{array}{c}\text { Time to } \\
\text { Maturity } \\
\left(\text { days }^{\dagger}\right)\end{array}$ & $\begin{array}{c}\text { We00 Seed } \\
(\mathrm{mg})\end{array}$ \\
\hline M1 (1448+1588+1760) & $100 \mathrm{a}^{\ddagger}$ & $431 \mathrm{~b}$ & $120 \mathrm{bcd}$ & $47.0 \mathrm{~b}$ & $83 \mathrm{~b}$ & $589 \mathrm{ab}$ \\
M2 $(907+1003+1214)$ & $100 \mathrm{a}$ & $384 \mathrm{~b}$ & $398 \mathrm{a}$ & $44.9 \mathrm{~b}$ & $76 \mathrm{c}$ & $513 \mathrm{c}$ \\
M3 $(864+907+1079+1229)$ & $100 \mathrm{a}$ & $312 \mathrm{~b}$ & $190 \mathrm{bc}$ & $44.0 \mathrm{~b}$ & $76 \mathrm{c}$ & $584 \mathrm{abc}$ \\
907 & $100 \mathrm{a}$ & $413 \mathrm{~b}$ & $233 \mathrm{~b}$ & $41.9 \mathrm{~b}$ & $76 \mathrm{c}$ & $514 \mathrm{c}$ \\
1003 & $100 \mathrm{a}$ & $340 \mathrm{~b}$ & $396 \mathrm{a}$ & $43.3 \mathrm{~b}$ & $76 \mathrm{c}$ & $584 \mathrm{abc}$ \\
1448 & $100 \mathrm{a}$ & $426 \mathrm{~b}$ & $44 \mathrm{~d}$ & $46.3 \mathrm{~b}$ & $83 \mathrm{~b}$ & $614 \mathrm{a}$ \\
1588 & $100 \mathrm{a}$ & $346 \mathrm{~b}$ & $39 \mathrm{~d}$ & $43.0 \mathrm{~b}$ & $83 \mathrm{~b}$ & $581 \mathrm{abc}$ \\
1760 & $100 \mathrm{a}$ & $484 \mathrm{~b}$ & $202 \mathrm{bc}$ & $43.0 \mathrm{~b}$ & $83 \mathrm{~b}$ & $527 \mathrm{bc}$ \\
Reubens & $100 \mathrm{a}$ & $785 \mathrm{a}$ & $101 \mathrm{~cd}$ & $70.6 \mathrm{a}$ & $109 \mathrm{a}$ & $224 \mathrm{~d}$ \\
Nugget & $100 \mathrm{a}$ & $530 \mathrm{~b}$ & $53 \mathrm{~d}$ & $43.9 \mathrm{~b}$ & $109 \mathrm{a}$ & $529 \mathrm{bc}$ \\
\hline \hline
\end{tabular}

${ }^{\dagger}$ Days from April 15 to maturity.

${ }^{\ddagger}$ Means within columns followed by the same letter are not significantly different by Duncan's new multiple range test $(\mathrm{P} \leq 0.05)$. $\mathrm{n}=4$ for all means. 

APPENDIX C

METEOROLOGICAL DATA FOR RESEARCH SITES 


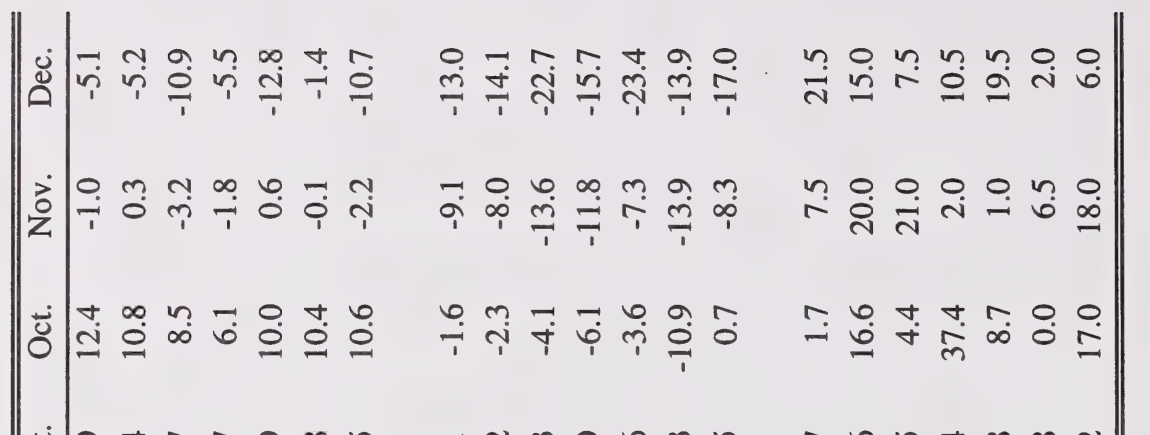

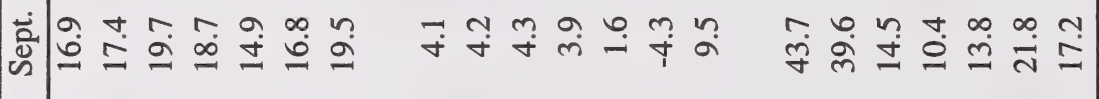

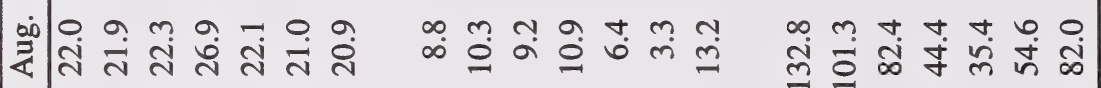



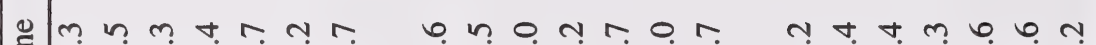

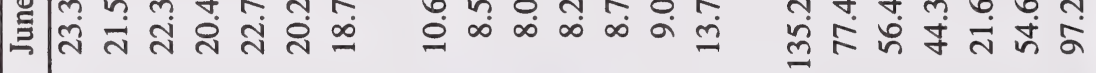

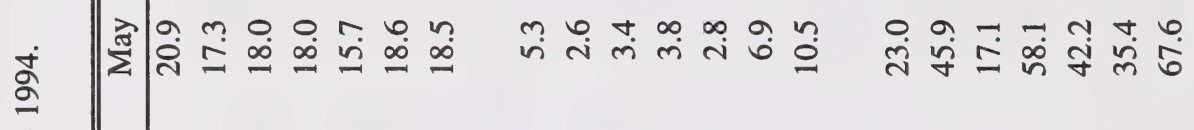

\%

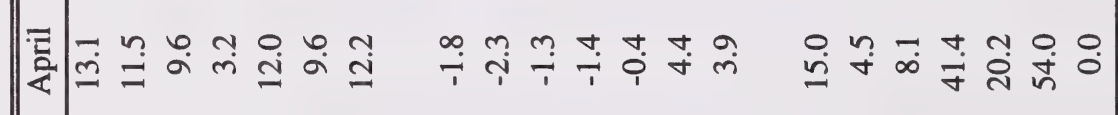

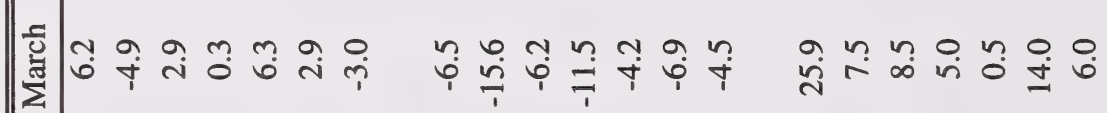
$\stackrel{0}{\frac{0}{3}}$

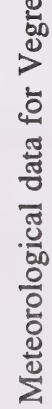

岂

ฐં ‡্ৰ 


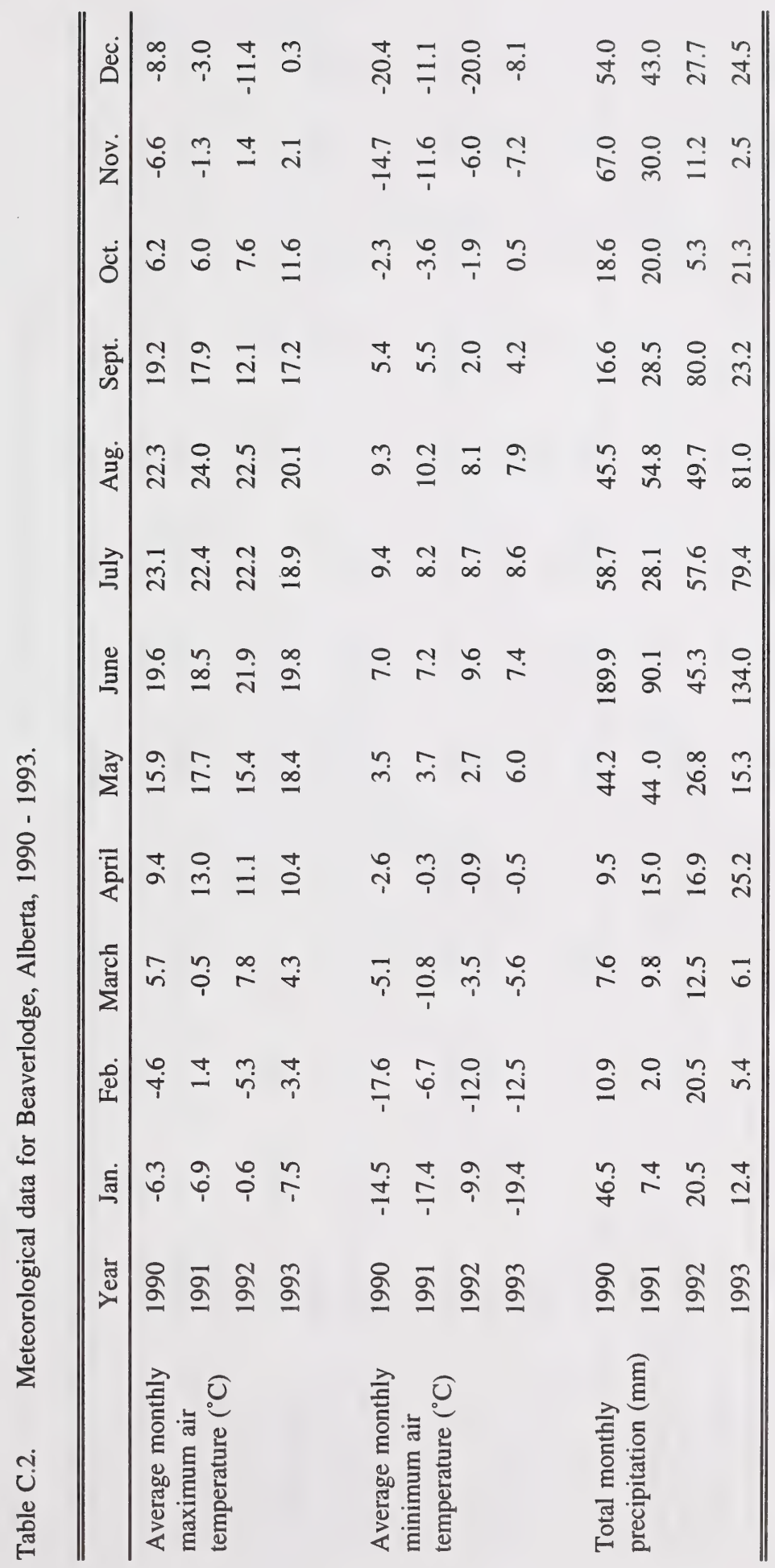









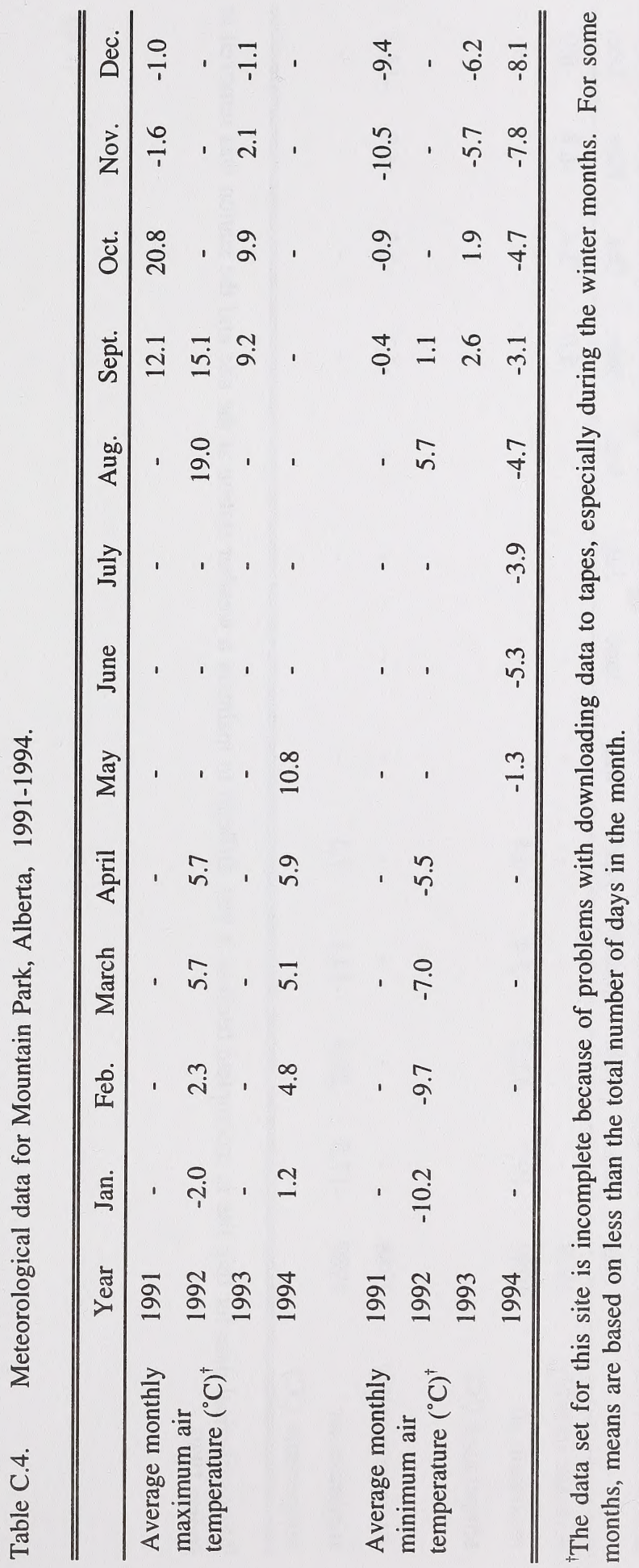










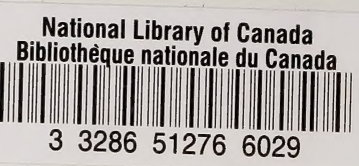

0 